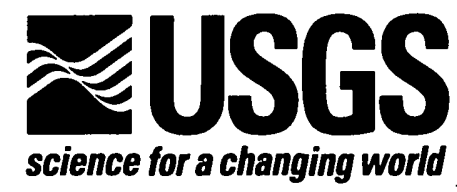

In cooperation with the Three Affiliated Tribes

\title{
Water Resources of the Fort Berthold Indian Reservation, West-Central North Dakota
}

Water-Resources Investigations Report 98-4098

U.S. Department of the Interior

U.S. Geological Survey 

U.S. Department of the Interior

U.S. Geological Survey

\title{
Water Resources of the Fort Berthold Indian Reservation, West-Central North Dakota
}

\author{
By Steven W. Cates and Kathleen M: Macek-Rowland
}

Water-Resources Investigations Report 98-4098

In cooperation with the Three Affiliated Tribes 


\section{U.S. DEPARTMENT OF THE INTERIOR BRUCE BABBITT, Secretary}

U.S. GEOLOGICAL SURVEY

THOMAS J. CASADEVALL, Acting Director

Any use of trade, product, or firm names is for descriptive purposes only and does not imply endorsement by the U.S. Government.

For additional information write to:

\section{District Chief}

U.S. Geological Survey

Water Resources Division

821 East Interstate Avenue

Bismarck, ND 58501

Copies of this report can be purchased from:

U.S. Geological Survey

Branch of Information Services

Box 25286

Denver, CO 80225-0286 


\section{CONTENTS}

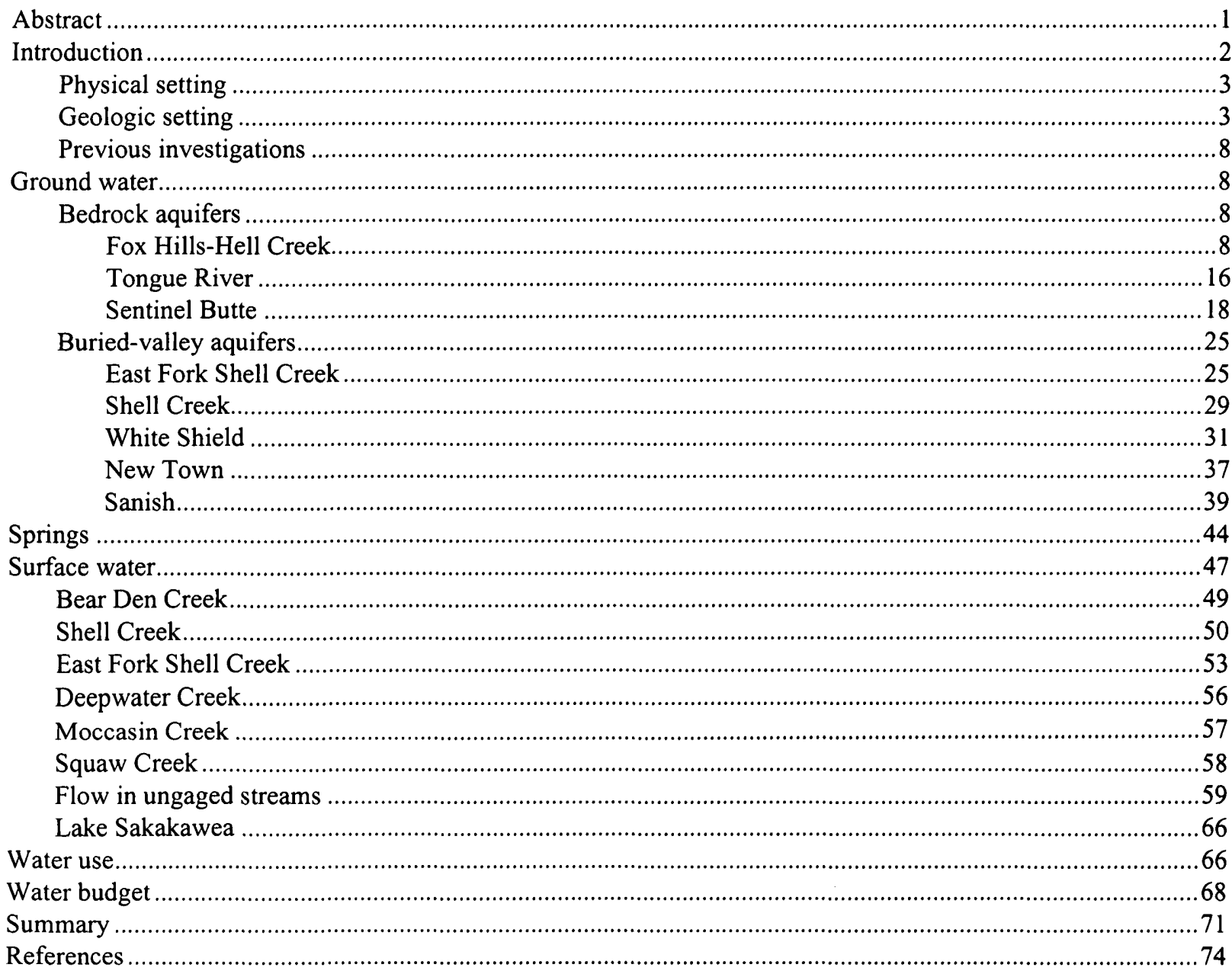

\section{FIGURES}

1. Map showing location of the Fort Berthold Indian Reservation, west-central North Dakota ............................4

2. Map showing generalized bedrock geology of the Fort Berthold Indian Reservation ......................................6

3. Map showing major structural features of the Fort Berthold Indian Reservation .............................................

4. Map showing locations of buried valleys on the Fort Berthold Indian Reservation ...........................................

5. Map showing altitude of the base of the Fox Hills-Hell Creek aquifer .....................................................11

6. Map showing potentiometric surface of the Fox Hills-Hell Creek aquifer, 1970-83 ......................................12

7. Hydrographs showing water levels in wells completed in the Fox Hills-Hell Creek aquifer,

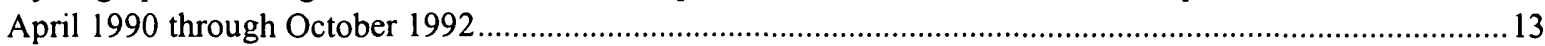

8. Hydrograph showing water level in a well completed in the Fox Hills-Hell Creek aquifer,

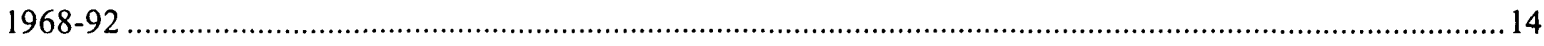

9. Diagram showing major-ion composition of water in the Fox Hills-Hell Creek aquifer .................................. 16

10. Diagram showing classification of irrigation water.................................................................................. 17

11. Map showing potentiometric surface of the Tongue River aquifer, 1979-92 .................................................19

12. Hydrographs showing water levels in wells completed in the Tongue River aquifer, April

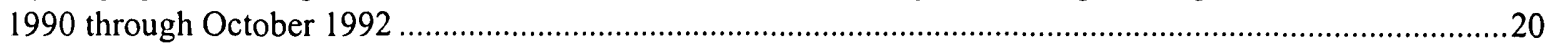

13. Diagram showing major-ion composition of water in the Tongue River aquifer.............................................22

14. Hydrographs showing water levels in wells completed in the Sentinel Butte aquifer, May 1990 through October 1992 


\section{FIGURES, Continued}

15. Diagram showing major-ion composition of water in the Sentinel Butte aquifer.....

16. Map showing locations of wells and test holes drilled into the East Fork Shell Creek, Shell Creek, New Town, and Sanish aquifers

17. Diagram showing geologic section A-A'through the East Fork Shell Creek and Shell Creek aquifers and altitude of the underlying bedrock

18. Hydrograph showing water level in a well completed in the East Fork Shell Creek aquifer, April 1990 through October 1992

19. Diagram showing major-ion composition of water in the East Fork Shell Creek aquifer................................29

20. Diagram showing major-ion composition of water in the Shell Creek aquifer ...............................................31

21. Diagram showing locations of selected wells and test holes drilled into the White Shield

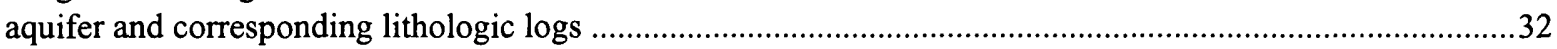

22. Map showing residual gravity in the eastern part of the Fort Berthold Indian Reservation..............................34

23. Map showing altitude of the top of the Fort Union Formation near the White Shield aquifer...........................35

24. Hydrographs showing water levels in wells completed in the eastern part of the White Shield aquifer and lake stage of Lake Sakakawea, 1970-92.

25. Hydrographs showing water levels in wells completed in the western part of the White Shield aquifer, 1970-92

26. Diagram showing major-ion composition of water in the eastern part of the White Shield aquifer ..................39

27. Diagram showing major-ion composition of water in the western part of the White Shield aquifer .................40

28. Diagram showing geologic section B-B' through the New Town aquifer and altitude of the underlying bedrock

29. Diagram showing geologic section $C-C^{\prime}$ through the New Town aquifer and altitude of the underlying bedrock

30. Hydrograph showing water level in a well completed in the New Town aquifer and lake stage of Lake Sakakawea, 1967-92

31. Diagram showing major-ion composition of water in the New Town aquifer.

32. Diagram showing geologic section D-D' through the Sanish aquifer and altitude of the underlying bedrock

33. Diagram showing major-ion composition of water in the Sanish aquifer .....

34. Diagram showing major-ion composition of water in springs on the Fort Berthold Indian Reservation...........50

35. Map showing locations of selected streams, drainage basins, continuous-record gaging stations, and miscellaneous discharge-measurement sites on and near the Fort Berthold Indian Reservation.

36. Graph showing daily mean streamflow at the Bear Den Creek near Mandaree, North Dakota, gaging station, April 1990 through September 1992.

37. Graph showing monthly mean streamflow statistics, $1970-92$, and mean monthly streamflow, 1990-92, at the Bear Den Creek near Mandaree, North Dakota, gaging station .....

38. Graph showing daily mean streamflow at the Shell Creek near Parshall, North Dakota, gaging station, September 1965 through September 1981

39. Graph showing daily mean streamflow at the East Fork Shell Creek near Parshall, North Dakota, gaging station, July 1991 through September 1992

40. Graph showing streamflow measurements at the East Fork Shell Creek near mouth below Parshall, North Dakota, miscellaneous discharge-measurement site, April 1990 through June 1991

41. Graph showing streamflow measurements at the Deepwater Creek at mouth near Raub,

North Dakota, miscellaneous discharge-measurement site, April 1990 through May 1991

42. Graph showing daily mean streamflow at the Deepwater Creek at mouth near Raub, North

Dakota, gaging station, July 1991 through September 1992

43. Graph showing streamflow measurements at the Moccasin Creek at mouth near Mandaree, North Dakota, miscellaneous discharge-measurement site, April 1990 through September 1992

44. Graph showing streamflow measurements at the Squaw Creek above mouth near Mandaree, North Dakota, miscellaneous discharge-measurement site, April 1990 through September 1992 


\section{FIGURES, Continued}

45. Graph showing monthend lake elevations for Lake Sakakawea for 1953-92 and mean lake elevations for 1970-92 and 1990-92

46. Map showing locations of selected continuous-record gaging stations, precipitation stations, and towns near the Fort Berthold Indian Reservation.

\section{TABLES}

1. Generalized geologic column of near-surface rocks of the Fort Berthold Indian Reservation ...........................5

2. Selected standards for inorganic constituents in drinking water in North Dakota ..........................................14

3. Statistical summary of selected water-quality data for the Fox Hills-Hell Creek aquifer, 1967-86

4. Statistical summary of selected water-quality data for the Tongue River aquifer, 1952-92 ..........................21

5. Statistical summary of selected water-quality data for the Sentinel Butte aquifer, 1950-92 ..........................24

6. Statistical summary of selected water-quality data for the East Fork Shell Creek aquifer, 1962-90 ................28

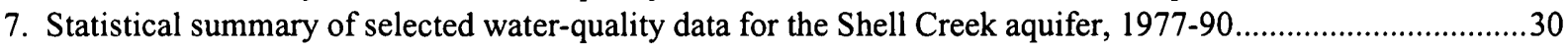

8. Statistical summary of selected water-quality data for the White Shield aquifer, 1966-92 .............................38

9. Statistical summary of selected water-quality data for the New Town aquifer, 1966-87................................44

10. Statistical summary of selected water-quality data for the Sanish aquifer, 1966-92 .......................................47

11. Statistical summary of selected water-quality data for springs on the Fort Berthold Indian

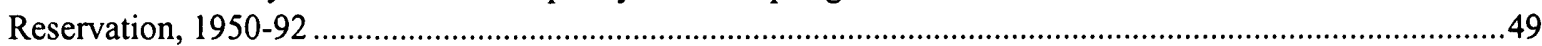

12. Selected basin characteristics for major streams on the Fort Berthold Indian Reservation...............................52

13. Statistical summary of streamflow data for selected continuous-record gaging stations and selected miscellaneous discharge-measurement sites on and adjacent to the Fort Berthold Indian Reservation

14. Statistical summary of selected water-quality data for Bear Den Creek near Mandaree, N. Dak., April 1990 through September 1992

15. Statistical summary of selected water-quality data for East Fork Shell Creek near Parshall, N. Dak., July 1991 through September 1992

16. Statistical summary of selected water-quality data for East Fork Shell Creek near mouth below Parshall, N. Dak., April 1990 through June 1991

17. Statistical summary of selected water-quality data for Deepwater Creek at mouth near Raub, N. Dak., April 1990 through September 1992

18. Statistical summary of selected water-quality data for Moccasin Creek at mouth near Mandaree, N. Dak., April 1990 through September 1992

19. Statistical summary of selected water-quality data for Squaw Creek above mouth near Mandaree, N. Dak., April 1990 through September 1992

20. Peak flows for major streams on the Fort Berthold Indian Reservation......................................................66

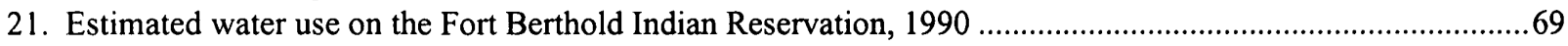

22. Selected water-budget component rates and storage values for the Fort Berthold Indian Reservation .............69 


\title{
Water Resources of the Fort Berthold Indian Reservation, West-Central North Dakota
}

\author{
By Steven W. Cates and Kathleen M. Macek-Rowland
}

\begin{abstract}
Water resources of the Fort Berthold Indian Reservation in west-central North Dakota occur as ground water in bedrock and buried-valley aquifers and as surface water in streams and Lake Sakakawea. The bedrock aquifers--the Fox Hills-Hell Creek, Tongue River, and Sentinel Butte-store about 93 million acre-feet of water under the Reservation. The Fox Hills-Hell Creek aquifer is composed mainly of very fine to medium-grained sandstone and stores about 51 million acrefeet of water. Water levels in the aquifer declined from 1976 through 1992. The Tongue River aquifer is composed mainly of claystones and siltstones and has widely distributed pockets of sandstone or lignite layers. The aquifer stores about 24 million acre-feet of water. The Sentinel Butte aquifer is composed mainly of interbedded claystones, siltstones, shale, lignite, and sandstone and stores about 18 million acre-feet of water. Yields from the lignite beds are highly variable. Water in the aquifers was predominantly a sodium bicarbonate type. Mean dissolvedsolids concentrations were 1,530 milligrams per liter in water from the Fox Hills-Hell Creek aquifer, 2,110 milligrams per liter in water from the Tongue River aquifer, and 1,300 milligrams per liter in water from the Sentinel Butte aquifer.
\end{abstract}

The East Fork Shell Creek, Shell Creek, White Shield, New Town, and Sanish aquifers occur within buried valleys and store about 1,414,000 acre-feet of water. The East Fork Shell Creek and Shell Creek aquifers are composed of sand and gravel lenses that are surrounded by lesspermeable till. Water in the East Fork Shell Creek aquifer is a sodium sulfate bicarbonate type, and water in the Shell Creek aquifer is a sodium bicarbonate sulfate type. Mean dissolved-solids concentrations were 3,220 milligrams per liter in water from the East Fork Shell Creek aquifer and 1,470 milligrams per liter in water from the Shell Creek aquifer.

The White Shield aquifer is composed of very fine to coarse sand and fine to coarse gravel. Water in the aquifer varies from a sodium bicarbonate sulfate type to a mixed calcium magnesium sodium bicarbonate sulfate type. Mean dissolved-solids concentrations were 1,080 milligrams per liter in water from the eastern part of the aquifer and 1,430 milligrams per liter in water from the western part of the aquifer. Water levels in the western part of the aquifer rose during 1970-92.

The New Town aquifer is composed of lenticular deposits of sand and gravel. Water in the aquifer is a calcium sodium bicarbonate sulfate type and had a mean dissolved-solids concentration of 1,390 milligrams per liter. Data indicate a close correspondence between ground-water levels and lake stage of Lake Sakakawea, implying a hydraulic connection between the aquifer and the lake. 
The Sanish aquifer is composed of sand, clayey sand, and thin gravels that are poorly cemented and highly permeable. Water in the aquifer is a mixed calcium magnesium bicarbonate sulfate type and had a mean dissolved-solids concentration of 1,350 milligrams per liter.

Major streams on the Reservation are Bear Den Creek, Shell Creek, East Fork Shell Creek, Deepwater Creek, Moccasin Creek, and Squaw Creek. Mean streamflow for Bear Den Creek for June 1966 through September 1992 was 6.72 cubic feet per second. Mean streamflow for Shell Creek for September 1965 through September 1981 was 12.9 cubic feet per second. Streamflow measurements for East Fork Shell Creek for April 1990 through June 1991 ranged from zero to 3.65 cubic feet per second, measurements for Deepwater Creek for April 1990 through May 1991 ranged from zero to 4.28 cubic feet per second, measurements for Moccasin Creek for April 1990 through September 1992 ranged from zero to 7.07 cubic feet per second, and measurements for Squaw Creek for April 1990 through September 1992 ranged from zero to 4.22 cubic feet per second.

Lake Sakakawea has a maximum surface area of 390,000 acres. The surface area is variable in relation to lake stage, which was unusually low during this study. The mean lake elevation for Lake Sakakawea for 1970-92 was 1,837.08 feet, and the mean lake elevation for 1990-92 was $1,821.14$ feet.

\section{INTRODUCTION}

An understanding of the quantity and quality of ground-water and surface-water resources is important for natural-resource management and for the development of policies related to water allocation, environmental protection, industrial development, and waste management. Information on the distribution, quantity, and quality of water on the Fort Berthold Indian Reservation was needed to develop a water-management plan for agricultural, municipal, domestic, and industrial uses; mineral development; and protection of instream flows and wetlands for fish and wildlife. Therefore, in 1990, the U.S. Geological Survey, in cooperation with the Three Affiliated Tribes, began a study to characterize the quantity, quality, and use of ground-water and surface-water resources of the Reservation.

Specific objectives of the study were to (1) describe the stratigraphy and distribution of aquifers underlying the Reservation; (2) investigate and describe the ground-water system, including the direction of movement, the recharge and discharge relations, the volume of ground water in storage, the hydraulic properties of the aquifers, and the quality of ground water; (3) improve the understanding of the surfacewater system by documenting the average streamflow, the year-to-year and seasonal variations in streamflow, and the quality of water in streams on the Reservation; (4) complete an inventory of current water use; and (5) develop geographic information system coverages. This report describes results associated with objectives 1 through 4 of the study.

Data were collected between January 1990 and December 1992 and were supplemented by historical data and information from previous investigations. Various geologic, ground-water, and surface-water techniques were used during the study. Test-hole drilling, geophysical logging of test holes, and a largescale, high-accuracy gravity survey were used to refine the geologic knowledge of the area; water-level measurements and water-quality samples from observation wells were used to describe ground-water resources; and streamflow measurements made monthly or more frequently at selected locations on the major drainages were used to describe surface-water resources. 


\section{Physical Setting}

The Fort Berthold Indian Reservation encompasses about 1,583 square miles in Dunn, Mercer, McKenzie, McLean, Mountrail, and Ward Counties in west-central North Dakota (fig. 1). Land-surface altitudes range from about 1,835 feet above sea level along Lake Sakakawea (variable with lake-stage changes) to more than 2,600 feet above sea level in Dunn County southwest of Mandaree.

Lake Sakakawea [formed in 1953 by impoundment of the Missouri River downstream (east) of the Reservation] is the largest surface-water body and most prominent feature on the Reservation. The lake is bounded on the north and east by areas of complex glacial moraines and on the south and west by outcrops of bedrock with scattered patches of glacial-remnant material. Rugged, deeply eroded badlands, formed when rivers eroded the glacial deposits and bedrock, occur in the area south and west of the lake.

Streams on the Reservation generally are ephemeral and have extended periods without flow. Major streams on the Reservation are Bear Den Creek, Shell Creek, East Fork Shell Creek, Deepwater Creek, Moccasin Creek, and Squaw Creek (fig. 1), but many unnamed, short, ephemeral streams also flow into Lake Sakakawea from deeply eroded, small drainage basins adjacent to the lake.

From 1971 to 1992, annual precipitation at Garrison, located about 20 miles east of the Reservation, varied widely from year to year and ranged from 9.45 inches in 1988 to 23.09 inches in 1975 (U.S. Department of Commerce, National Oceanic and Atmospheric Administration, Environmental Data Service, 1972-93). Average annual precipitation for the Reservation is about 16 inches. About 70 percent of the precipitation occurs during the growing season (May to September), but the amount of rainfall is extremely variable monthly and spatially across the Reservation.

\section{Geologic Setting}

Near-surface sedimentary units on the Reservation include all rocks above the Cretaceous-age Pierre Shale, a marine shale as much as 2,300 feet thick. In western North Dakota, the top of the Pierre Shale may be considered the base of freshwater-bearing units. Rocks overlying the Pierre Shale include, in ascending order, the Cretaceous-age Fox Hills Sandstone and Hell Creek Formation, the Tertiary-age Fort Union Formation and Golden Valley Formation, and the Quaternary-age deposits of glacial drift and alluvium. The maximum thicknesses and predominant lithologies of the stratigraphic units above the base of the Pierre Shale are shown in table 1. The bedrock geology of the Reservation is shown in figure 2.

The Fox Hills Sandstone and the Hell Creek Formation were deposited in a deltaic environment. The Fort Union Formation includes the Ludlow, Tongue River, and Sentinel Butte Members, which are continental units that were deposited in a generally westward-transgressing sea on an alluvial plain, and the Cannonball Member, which is a marine equivalent and interfingers with the Ludlow Member. The Golden Valley Formation was deposited as fluvial point-bar sediments and flood-plain deposits.

The Williston Basin, a structural feature centered west of the Reservation, affects the thickness of the bedrock units of Cretaceous age and older. The Tertiary-age units on the Reservation are relatively horizontal or have westward dips of less than 10 feet per mile, although some small structures have dips that exceed 150 feet per mile (Dingman and Gordon, 1954). Major structural features on the Reservation include the Nesson Anticline and the Antelope Anticline (fig. 3). Lineaments that may indicate fractures in the underlying rocks are evident in aerial photographs. Correlation of the linear features with subsurface data indicates that several faults (fig. 3) occur on the Reservation (Bluemle, 1978). 


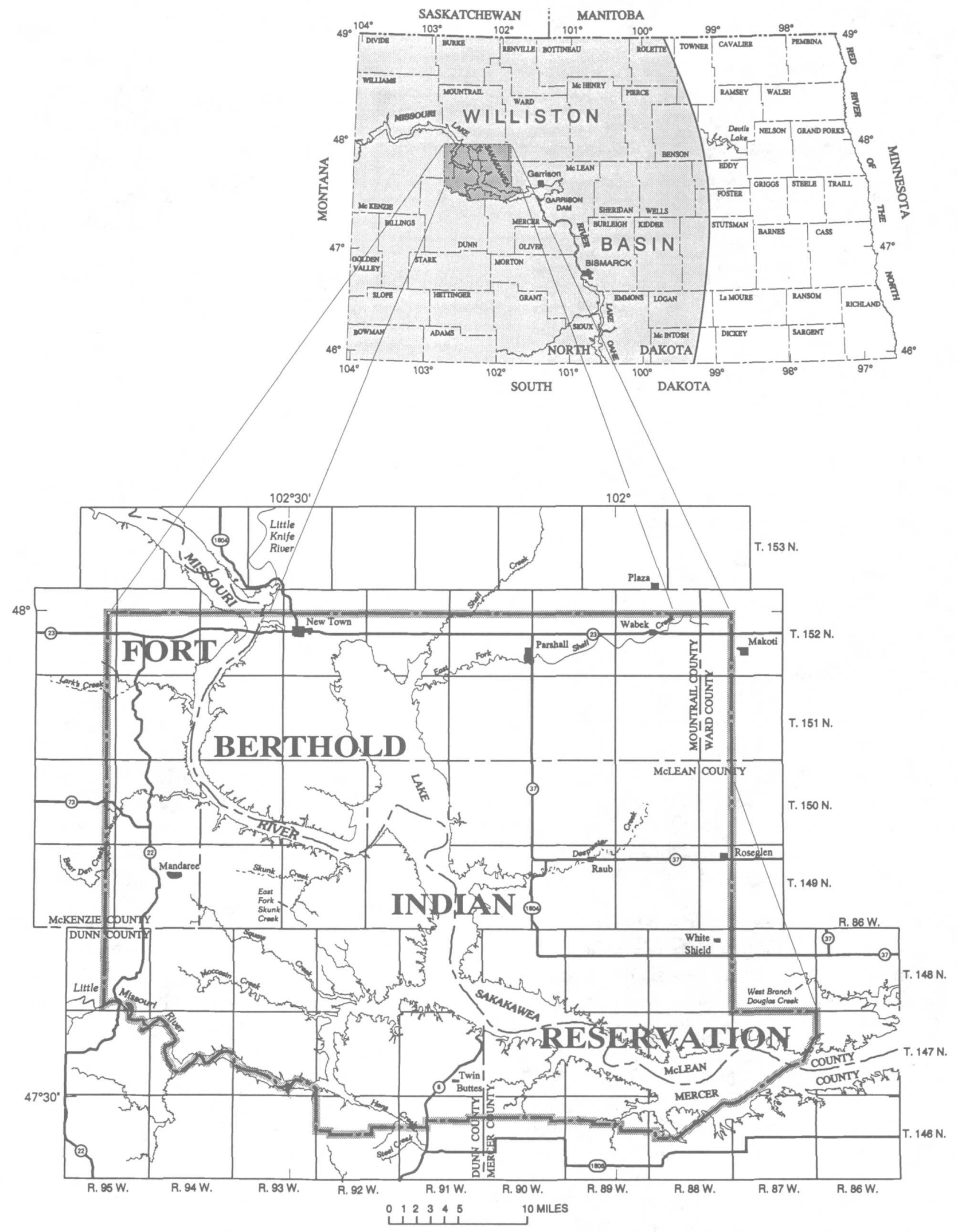

Figure 1. Location of the Fort Berthold Indian Reservation, west-central North Dakota. 


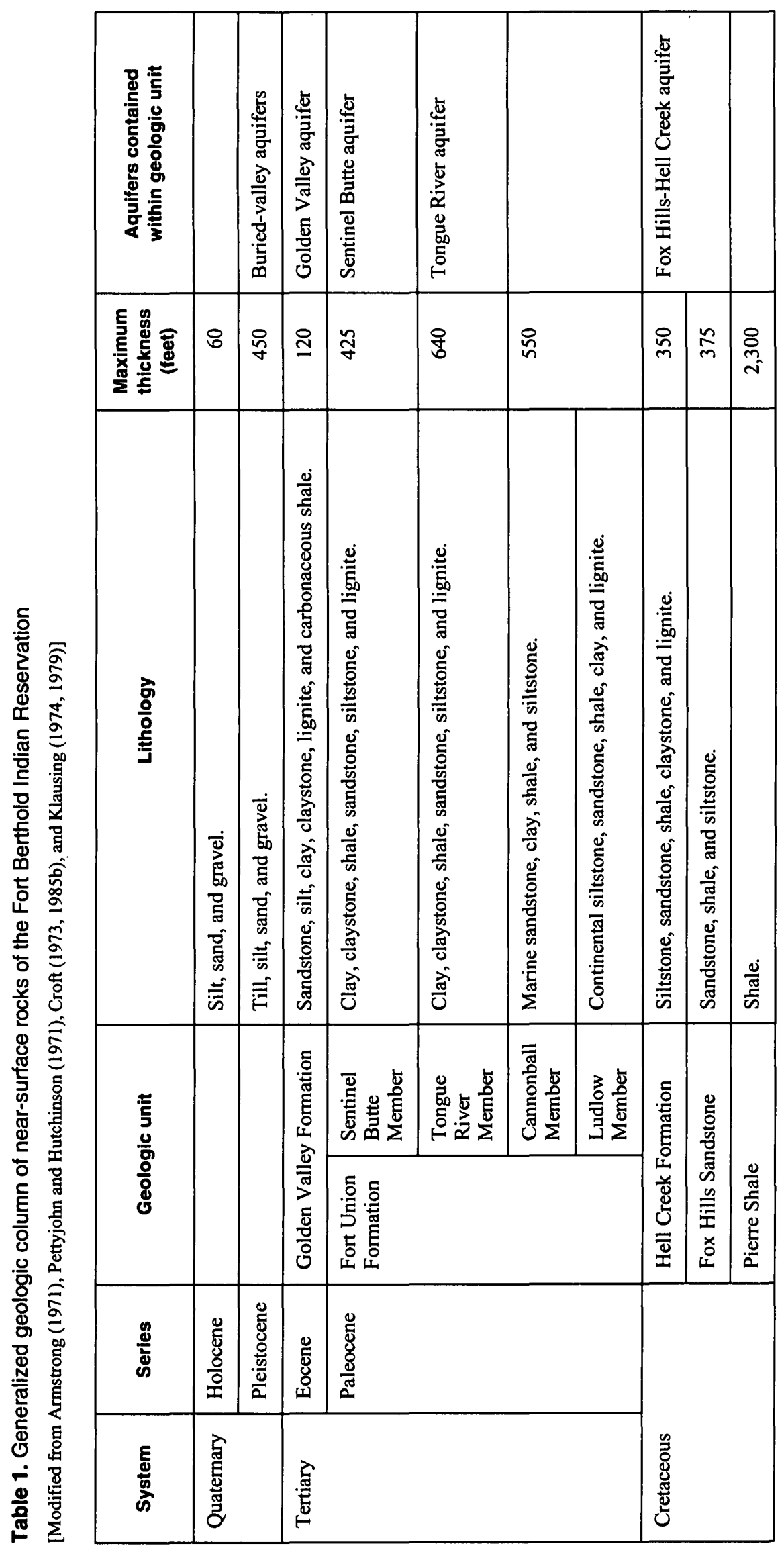




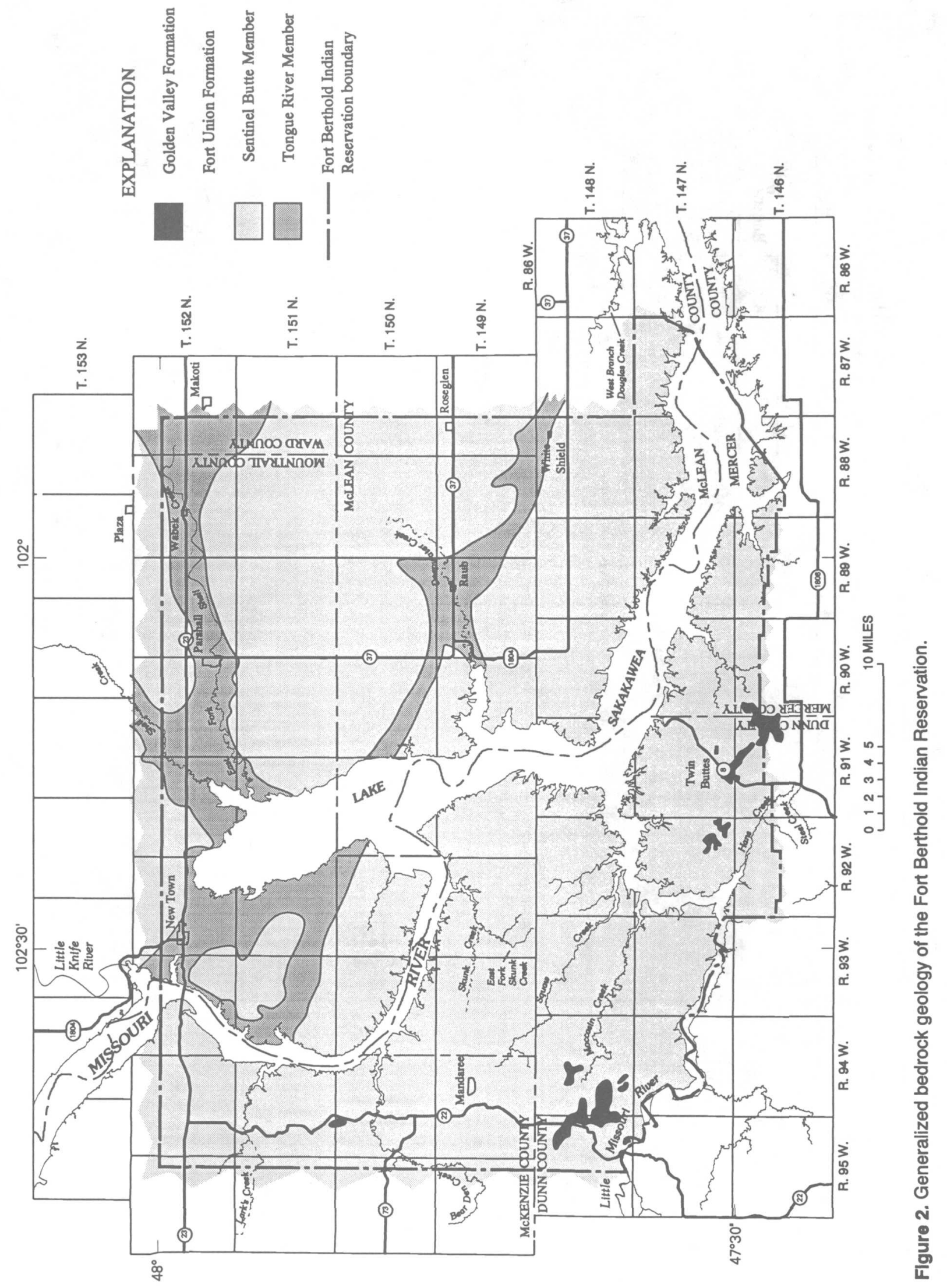




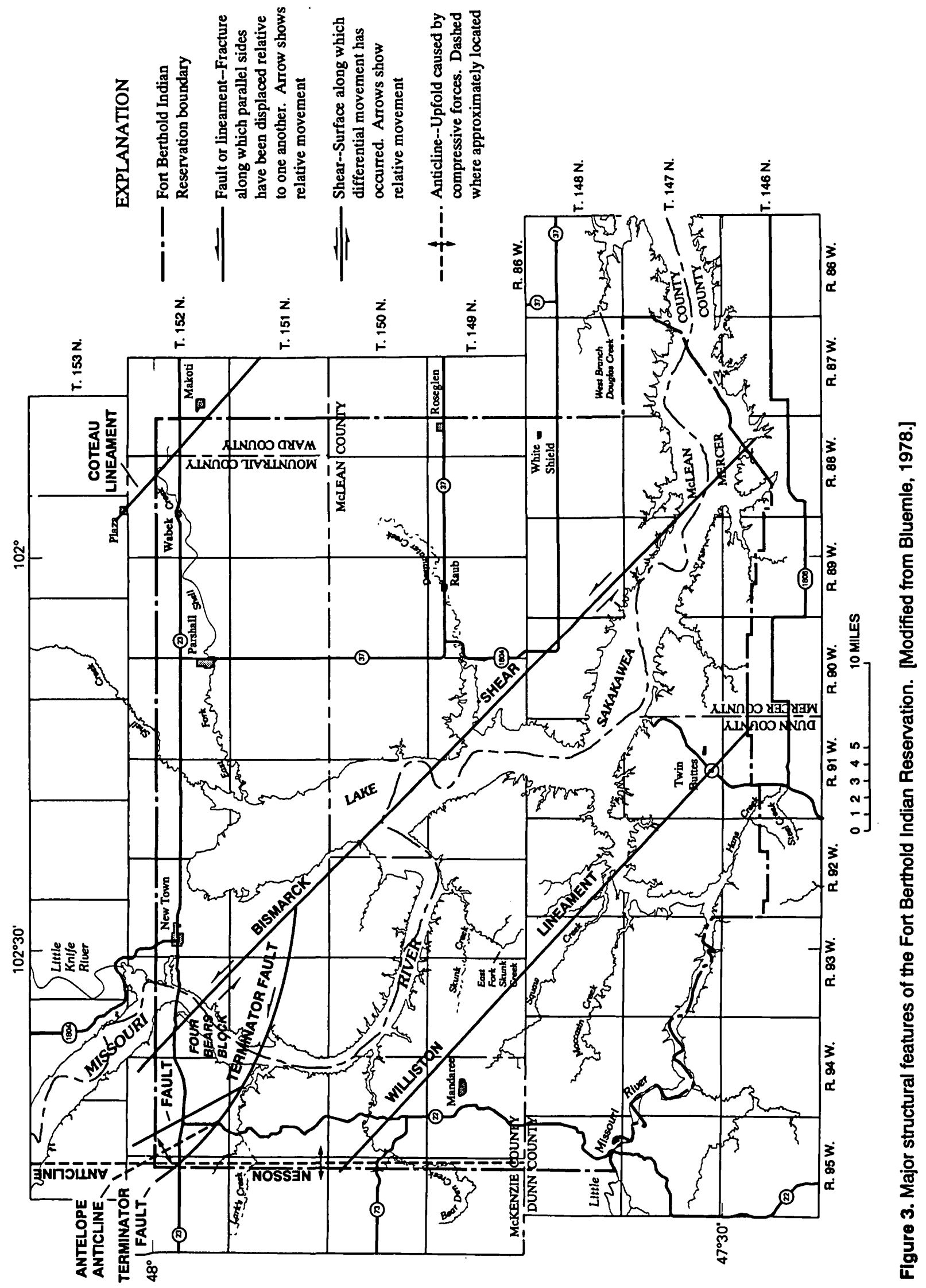


During the Pleistocene, glaciers advanced across central Canada and extended southward over most of the Reservation. Rivers that flowed from the Rocky Mountains northeastward to Hudson Bay were diverted by the glaciers and forced to flow southward into the Mississippi River Basin. Glacially-derived material covers about 50 percent of the Reservation, mostly north and east of Lake Sakakawea. Although glacial remnants are evident south and west of the lake, the remnants are scattered, isolated, and thin. Pleistocene-age sands and gravels on the Reservation generally were deposited by large rivers fed by melting glaciers. The East Fork Shell Creek, Shell Creek, White Shield, New Town, and Sanish buried valleys (fig. 4) occur beneath a veneer of glacial till. The buried valleys are filled by Pleistocene-age glacial sediments and Holocene-age fluvial sediments that were deposited on the underlying, eroded Tongue River and Sentinel Butte Member sediments. Most of the sand and gravel deposits within the buried valleys are horizontally layered lenses that generally have limited lateral extent.

The buried-valley depositional model of Shaver and Pusc (1992) was used to interpret sediment distribution on the Reservation. The sediment distribution indicated the possible presence of tributary paleochannels and also alluvial-fan features at the mouths of the channels. Therefore, a high-accuracy gravity survey was conducted as part of this study to delineate buried valleys underlying the Reservation. Small-scale, local anomalies were expected at the locations of the paleochannels because of density contrasts between the glacial and bedrock materials. Using global positioning system technology, nearly 1,800 gravity stations were positioned in an 800-square-mile area of the Reservation north of Lake Sakakawea (Wald and Cates, 1995) where glacial material covers the bedrock. Test holes were drilled at locations where anomalies in the high-accuracy gravity data indicated the possible presence of paleochannels. Buried-channel deposits were located at seven of nine test holes, verifying the use of a high-accuracy gravity survey to delineate buried valleys.

\section{Previous Investigations}

The geology and hydrogeology of the Fort Berthold Indian Reservation were investigated by Dingman and Gordon (1954). Their investigation was conducted when the area of the Reservation was about 500 square miles less than its current area and before the Missouri River was impounded to form Lake Sakakawea.

Reconnaissance ground-water studies for each of the counties on the Reservation were conducted by the U.S. Geological Survey in cooperation with the North Dakota State Water Commission and the North Dakota Geological Survey. Results for each of the studies were published in a three-part series of reports. The first part describes the geology of the Reservation (Bluemle, 1971, 1989; Clayton, 1972; Carlson, 1973, 1985); the second part presents data about the water resources of the Reservation (Pettyjohn, 1968; Armstrong, 1969; Croft, 1970, 1985a; Klausing, 1971, 1976); and the third part describes the characteristics of the various aquifers (Armstrong, 1971; Pettyjohn and Hutchinson, 1971; Croft, 1973, 1985b; Klausing, 1974, 1979). A detailed hydrologic investigation of the Parshall area was conducted by Schmid and Ziegler (1962).

\section{GROUND WATER}

\section{Bedrock Aquifers}

\section{Fox Hills-Hell Creek}

The Fox Hills Sandstone consists mainly of brown shale and massive, fossiliferous, white marine sandstone. The Hell Creek Formation consists mainly of light-gray sands and clays of both fluvial- and 


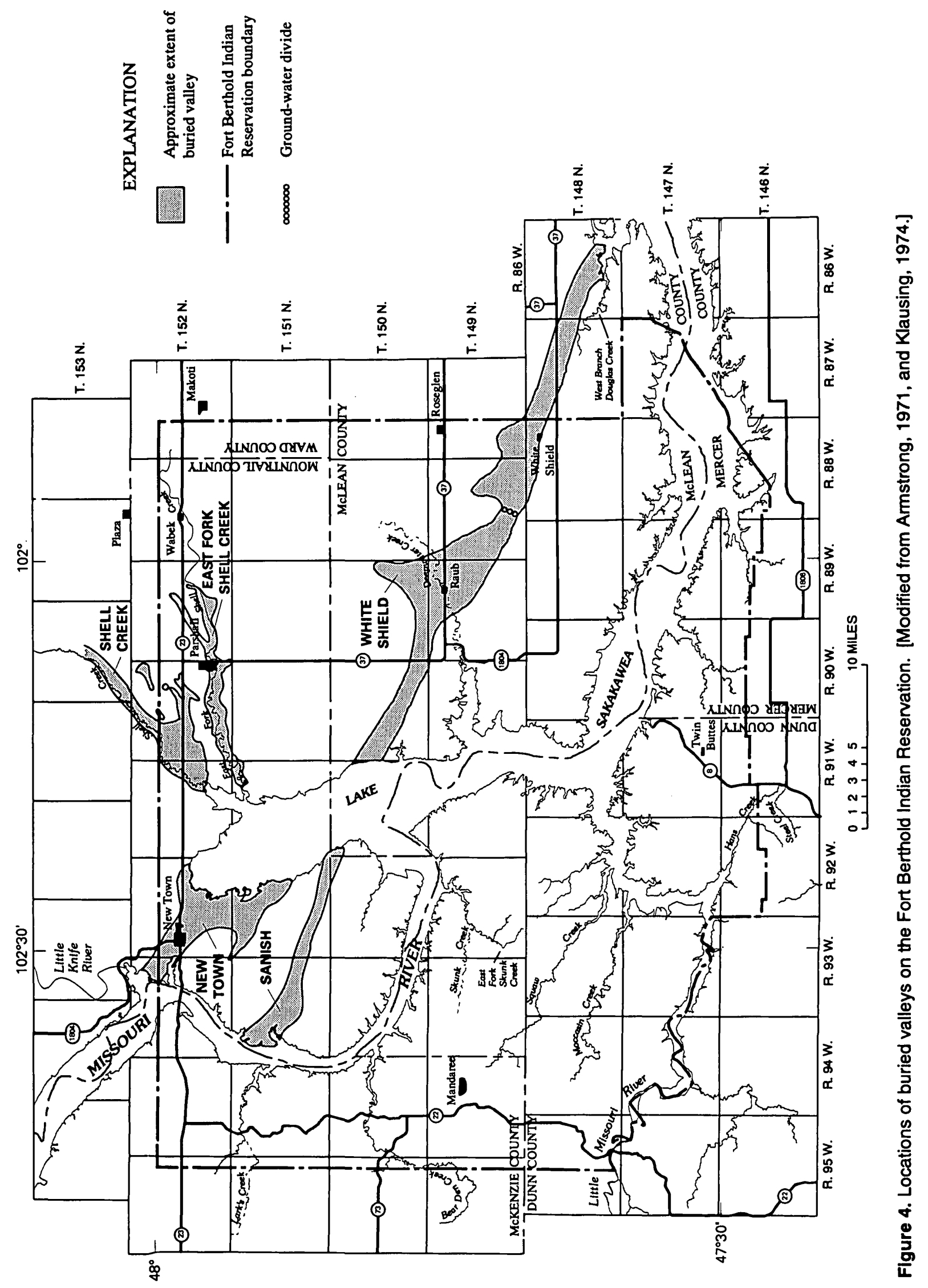


marine-sediment origin. Sandstone beds in the upper Fox Hills Sandstone and the lower Hell Creek Formation apparently are connected hydrologically (Armstrong, 1971). Therefore, the water-producing interval within the two formations is considered to be a single aquifer. This aquifer, the Fox Hills-Hell Creek aquifer, is composed mainly of very fine to medium-grained sandstone interbedded with siltstone and shale. The aquifer underlies the entire Reservation and ranges from 100 to 350 feet in thickness in the area of the Reservation.

The altitude of the base of the aquifer (fig. 5) ranges from about 295 to 877 feet above sea level. Structure contours of the base of the aquifer indicate a steep slope in the northwestern corner of the Reservation.

Transmissivity of the aquifer ranges from about 180 to 260 feet squared per day. Transmissivity was determined using values related to formation factors calculated from resistivity curves of induction logs (Croft, 1985b). Some of the wells developed in the Fox Hills-Hell Creek aquifer (especially those in the Dunn County part of the Reservation) flow at land surface under artesian pressure at a rate of about 100 gallons per minute (Croft, 1973, 1985b; Klausing, 1979). Previous studies indicate large variability in well yields. Wells that tap the Fox Hills-Hell Creek aquifer could yield 3 gallons per minute in the Mountrail County part of the Reservation (Armstrong, 1971) and between 200 and 400 gallons per minute in the Dunn County part of the Reservation (Klausing, 1979). Based on an areal extent of 1,583 square miles, an average cumulative thickness of 200 feet, and an assumed porosity of 25 percent, the volume of water stored in the Fox Hills-Hell Creek aquifer is about 51 million acre-feet.

A potentiometric-surface map based on water levels in the Fox Hills-Hell Creek aquifer during 197083 (fig. 6) indicates that ground water in the aquifer generally flows from northwest to southeast across the Reservation. Ground water in much of the northwestern and southwestern parts of the Reservation flows into a trough-shaped feature in the potentiometric surface toward the southeast. The axis of the trough coincides approximately with the Bismarck Shear (fig. 3) and, therefore, ground-water flow in the aquifer may be controlled, in part, by the Bismarck Shear. The hydraulic gradient ranges from 1 foot per mile in the northern part of the Reservation to about 40 feet per mile in the south-central part of the Reservation. The increase in gradient may be caused by the discharge of water from numerous flowing wells in or adjacent to the Missouri River Valley (Klausing, 1979) and by structural features that affect ground-water flow.

Hydrographs of four wells completed in the Fox Hills-Hell Creek aquifer (fig. 7) near the Reservation indicate that, during the nearly 3-year period when monthly water-level measurements were made, water levels in the aquifer generally declined. The hydrograph for well 146-090-20CCC [refers to township, range, section, and quarter-quarter-quarter section as explained in Wald and Cates (1995)] includes waterlevel data for 25 years and indicates an average decline of almost 1 foot per year from 1976 through 1992 (fig. 8).

Direct recharge to the Fox Hills-Hell Creek aquifer occurs outside of the Reservation where the aquifer crops out in the extreme southwestern corner of North Dakota and in eastern Montana. Within the Reservation, recharge results from downward movement of ground water from overlying aquifers. The potentiometric surface of the aquifer is higher than the land surface at several locations, especially in the Little Missouri River Valley and near Lake Sakakawea. Discharge from the aquifer is by lateral movement of water to adjacent areas, upward leakage of water to overlying aquifers, flowing wells, and well pumpage.

State water-quality standards apply only to ground water used for a community water supply, defined as a public system that serves at least 25 residents year-round (North Dakota Department of Health, 1994). 


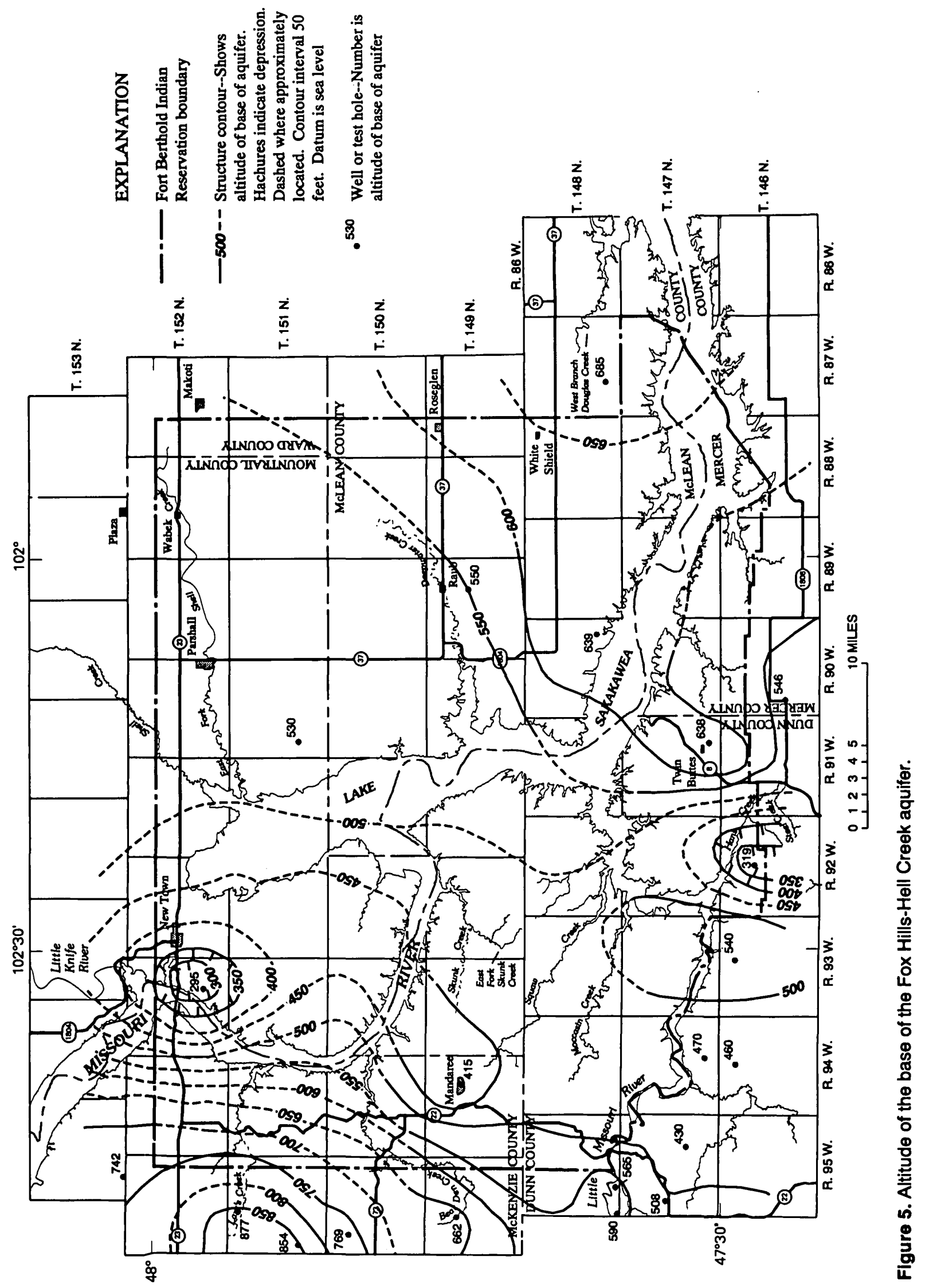




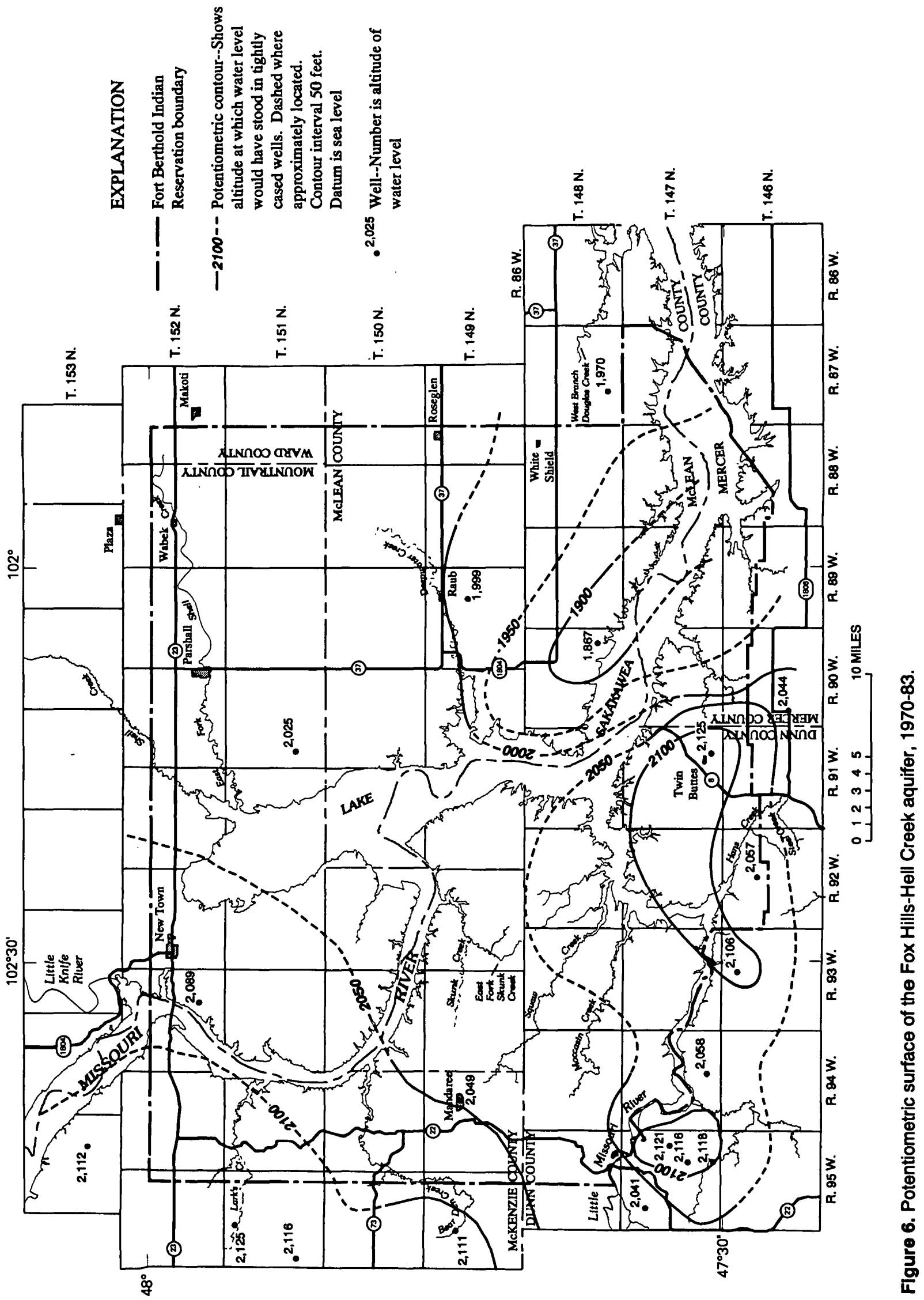




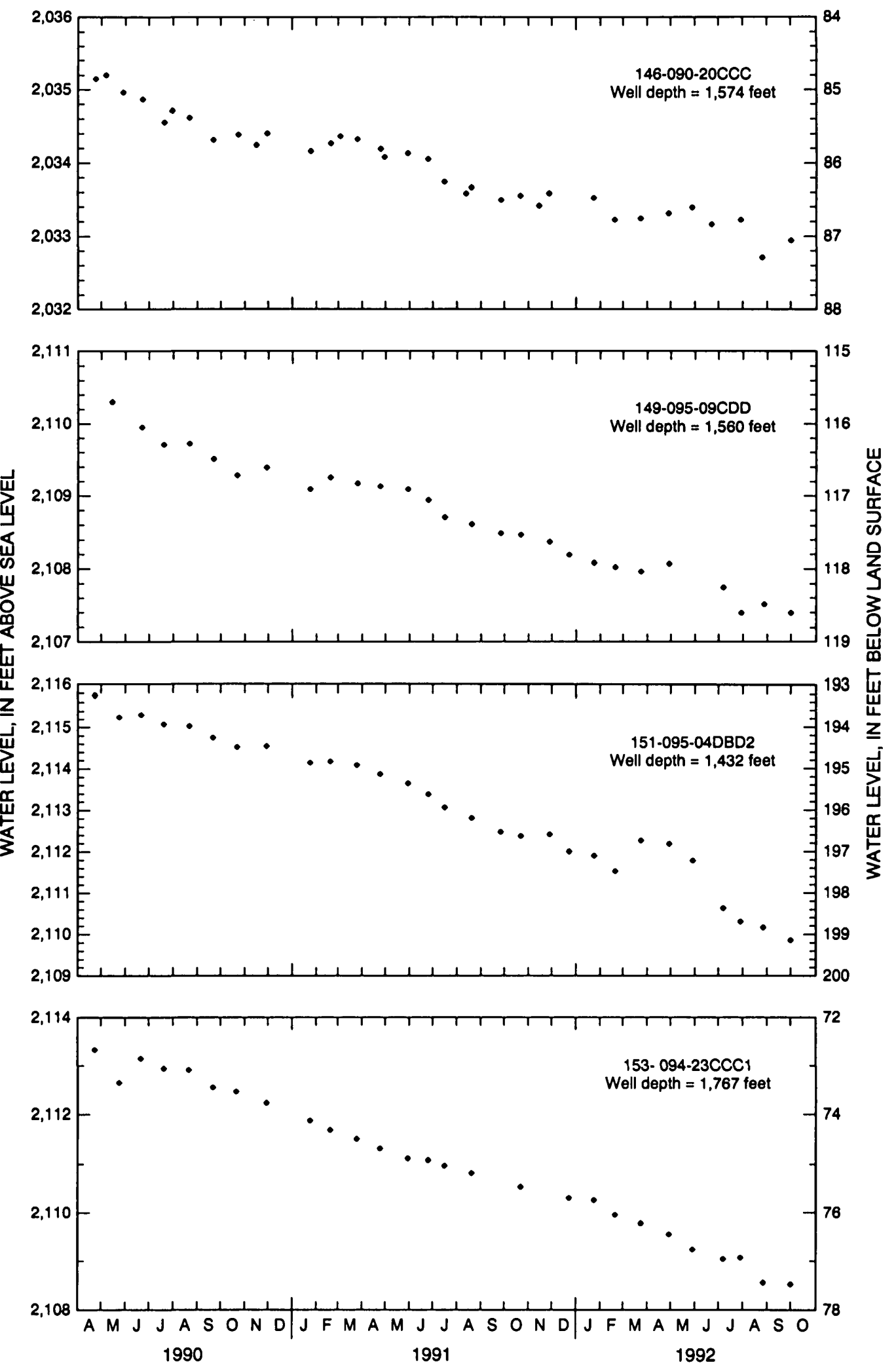

Figure 7. Water levels in wells completed in the Fox Hills-Hell Creek aquifer, April 1990 through October 1992. 


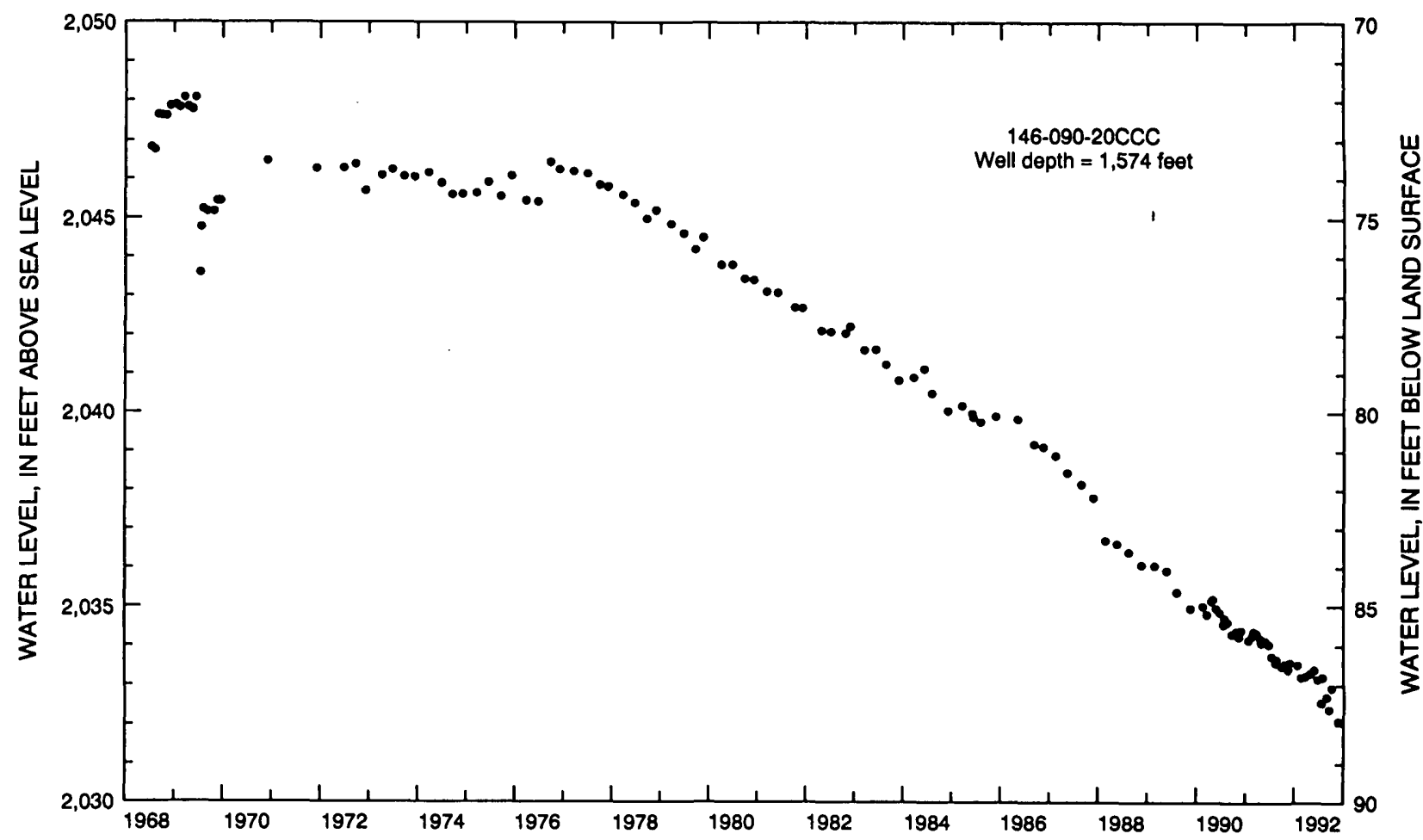

Figure 8. Water level in a well completed in the Fox Hills-Hell Creek aquifer, 1968-92.

Individual private wells do not have to comply with State standards. However, the quality of water from private wells can be compared with State drinking-water standards to determine if the water may pose a threat to human health. State drinking-water standards (North Dakota Department of Health, 1994) and secondary maximum contaminant levels (U.S. Environmental Protection Agency, 1996) for constituents detected in water samples collected from the Reservation are given in table 2 . The secondary maximum contaminant levels are for those constituents that affect the taste or odor of the water.

Table 2. Selected standards for inorganic constituents in drinking water in North Dakota

[Concentrations from North Dakota Department of Health (1994) and U.S. Environmental Protection Agency (1996); mg/L, milligrams per liter; $\mu \mathrm{g} / \mathrm{L}$, micrograms per liter]

\begin{tabular}{|c|c|c|}
\hline Constituent & Concentration & \\
\hline \multicolumn{2}{|c|}{ North Dakota drinking-water standards } & \\
\hline Fluoride $(\mathrm{mg} / \mathrm{L})$ & 4 & \\
\hline Nitrate $(\mathrm{mg} / \mathrm{L}$ as $\mathrm{N})$ & 10 & \\
\hline \multicolumn{2}{|c|}{ U.S. Environmental Protection Agency secondary maximum contaminant levels } & \\
\hline $\mathrm{pH}$ (standard units) & 6.5 to 8.5 & \\
\hline Sulfate $(\mathrm{mg} / \mathrm{L})$ & 250 & \\
\hline Chloride $(\mathrm{mg} / \mathrm{L})$ & 250 & \\
\hline Dissolved solids (mg/L) & 500 & \\
\hline Iron $(\mu \mathrm{g} / \mathrm{L})$ & 300 & \\
\hline Manganese $(\mu \mathrm{g} / \mathrm{L})$ & 50 & \\
\hline
\end{tabular}


A statistical summary of selected water-quality data for the Fox Hills-Hell Creek aquifer is given in table 3. The data pertain to samples collected from 19 wells completed in the aquifer during 1967-86. If more than one sample was collected from a well, only the most recent sample was used in the summary. Generally, water in the aquifer is a sodium bicarbonate type (fig. 9). Dissolved-solids concentrations ranged from 1,230 to 2,190 milligrams per liter and had a median of 1,470 milligrams per liter. Dissolvedsolids concentrations in all samples collected from the aquifer exceeded the secondary maximum contaminant level of 500 milligrams per liter (table 2). Maximum sulfate, chloride, iron, and manganese concentrations also exceeded the secondary maximum contaminant levels.

Table 3. Statistical summary of selected water-quality data for the Fox Hills-Hell Creek aquifer, 1967-86 $\left[\mu \mathrm{S} / \mathrm{cm}\right.$, microsiemens per centimeter; ${ }^{\circ} \mathrm{C}$, degrees Celsius; --, not available; $\mathrm{mg} / \mathrm{L}$, milligrams per liter; <, less than; $\mu \mathrm{g} / \mathrm{L}$, micrograms per liter]

\begin{tabular}{|c|c|c|c|c|c|}
\hline $\begin{array}{l}\text { Physical property or } \\
\text { chemical constituent }\end{array}$ & $\begin{array}{l}\text { Number of } \\
\text { samples }\end{array}$ & Maximum & Minimum & Mean & Median \\
\hline Specific conductance, field $\left(\mu \mathrm{S} / \mathrm{cm}\right.$ at $\left.25^{\circ} \mathrm{C}\right)$ & 18 & 3,080 & 2,020 & 2,480 & 2,420 \\
\hline $\mathrm{pH}$, field (standard units) & 17 & 8.7 & 8.1 & -- & 8.2 \\
\hline Hardness $\left(\mathrm{mg} / \mathrm{L}\right.$ as $\left.\mathrm{CaCO}_{3}\right)$ & 19 & 24 & 6 & 12 & 9 \\
\hline Calcium, dissolved (mg/L) & 19 & 6.2 & 1.8 & 3.0 & 2.6 \\
\hline Magnesium, dissolved (mg/L) & 19 & 3.2 & 0.2 & 1.0 & 0.7 \\
\hline Sodium, dissolved (mg/L) & 19 & 820 & 500 & 625 & 600 \\
\hline Sodium adsorption ratio & 19 & 100 & 62 & 83 & 82 \\
\hline Potassium, dissolved (mg/L) & 19 & 4.1 & 1.5 & 2.4 & 1.9 \\
\hline Bicarbonate, field (mg/L as $\left.\mathrm{CaCO}_{3}\right)$ & 17 & 1,690 & 1,100 & 1,290 & 1,190 \\
\hline Alkalinity, lab, total $\left(\mathrm{mg} / \mathrm{L}\right.$ as $\left.\mathrm{CaCO}_{3}\right)$ & 14 & 1,390 & 935 & 1,090 & 994 \\
\hline Sulfate, dissolved (mg/L) & 19 & 550 & $<0.1$ & 50 & 8.4 \\
\hline Chloride, dissolved $(\mathrm{mg} / \mathrm{L})$ & 19 & 290 & 82 & 189 & 180 \\
\hline Fluoride, dissolved (mg/L) & 19 & 6.5 & 1.6 & 4.4 & 4.9 \\
\hline Silica, dissolved $(\mathrm{mg} / \mathrm{L})$ & 19 & 18 & 1.0 & 13 & 14 \\
\hline Dissolved solids, sum of constituents (mg/L) & 19 & 2,190 & 1,230 & 1,530 & 1,470 \\
\hline Nitrate, dissolved ( $\mathrm{mg} / \mathrm{L}$ as $\mathrm{N}$ ) & 13 & 0.23 & 0.14 & 0.22 & 0.23 \\
\hline Boron, dissolved $(\mu \mathrm{g} / \mathrm{L})$ & 19 & 3,200 & 320 & 1,760 & 1,600 \\
\hline Iron, dissolved $(\mu \mathrm{g} / \mathrm{L})$ & 19 & 530 & $<10$ & 140 & 80 \\
\hline Manganese, dissolved $(\mu \mathrm{g} / \mathrm{L})$ & 17 & 60 & $<10$ & 20 & 10 \\
\hline Strontium, dissolved $(\mu \mathrm{g} / \mathrm{L})$ & 1 & 600 & -- & -- & -. \\
\hline
\end{tabular}

The suitability of water for irrigation is related to the salinity and sodium hazards. Salinity, which is the dissolved-solids concentration, is proportional to specific conductance and is important because some crops do not grow well in saline soils. Sodium is important because the amount of exchangeable sodium, which is proportional to the sodium adsorption ratio, causes soil-structure damage. Because crops react differently to salinity and sodium, general guidelines have been developed for irrigation (fig. 10). Water that has a low to medium salinity hazard is suitable for irrigation, but water that has a high salinity hazard is unsuitable for irrigation. Water that has a low sodium hazard is suitable for irrigation on almost all soils, but water that has a medium sodium hazard is unsuitable for irrigation on fine-textured soils. 


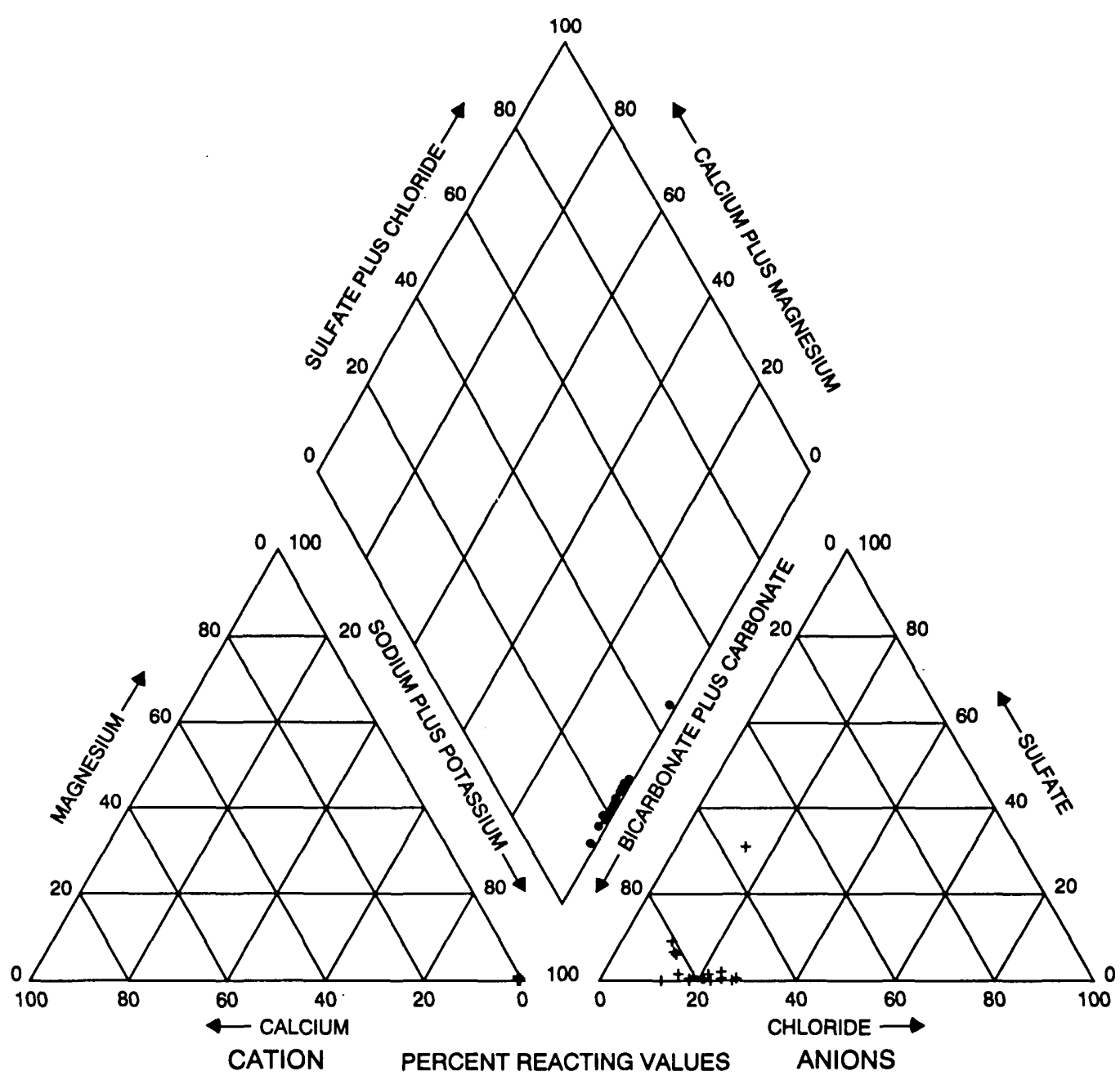

Figure 9. Major-ion composition of water in the Fox Hills-Hell Creek aquifer.

The sodium hazard for water from the Fox Hills-Hell Creek aquifer, as indicated by the sodium adsorption ratio (table 3 ), is very high (exceeding the scale shown in figure 10). The salinity hazard, as indicated by the specific-conductance value, also is very high. The combination of these two hazards indicates that water from the Fox Hills-Hell Creek aquifer is unsuitable for irrigation.

\section{Tongue River}

The Tongue River aquifer underlies the entire Reservation and crops out southwest of New Town. The aquifer is composed mainly of claystones and siltstones and has widely distributed pockets of sandstone or lignite layers. Although claystone and siltstone are the dominant sediments in the Tongue River Member, lignite beds are common and may be as thick as 15 feet. These lignite beds are a major source of ground water on the Reservation.

Hydraulic conductivity in the Tongue River aquifer underlying Dunn County ranges from 0.01 to 0.95 foot per day (Klausing, 1979). The hydraulic conductivity was determined from laboratory analyses of sidewall cores and from single-well slug tests. Groenewold and others (1979) determined ranges of 

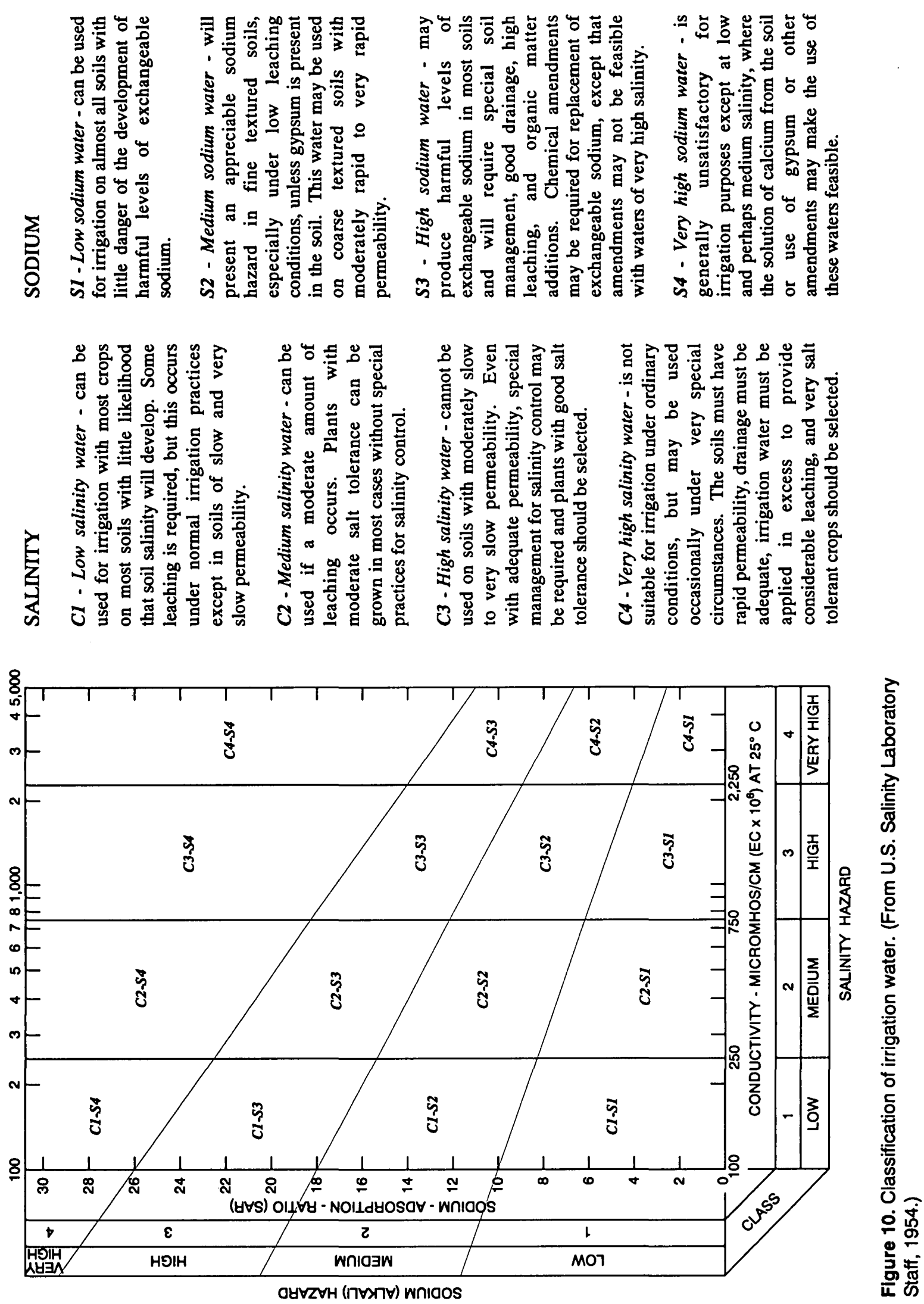
hydraulic conductivity in terms of sediment types in the Fort Union Formation in western North Dakota. These values range from $1.42 \times 10^{-4}$ to $1.42 \times 10^{-3}$ foot per day for silt and clay, $5.66 \times 10^{-2}$ to 5.66 feet per day for sand, and $2.8 \times 10^{-3}$ to 8.49 feet per day for lignite.

Yields from the Tongue River aquifer depend on local hydraulic properties. Lignites in the upper part of the Tongue River Member are variable in lateral extent, thickness, and degree of fracture. Therefore, yields from the lignite zones are variable but generally are larger than yields from sandstone zones of similar thickness (Armstrong, 1971). Well yields for the Tongue River aquifer range from 10 to as much as 200 gallons per minute (Klausing, 1979; Croft, 1985b). Based on an areal extent of 1,583 square miles, an average cumulative thickness of 80 feet, and an assumed porosity of 30 percent, the volume of water stored in the Tongue River aquifer is about 24 million acre-feet.

A potentiometric-surface map based on water levels in the Tongue River aquifer during 1979-92 (fig. 11) indicates that ground water in the aquifer generally flows toward the Missouri River and Lake Sakakawea. The hydraulic gradient in the aquifer generally corresponds with the topography of the Reservation.

Hydrographs of four wells completed in the Tongue River aquifer (fig. 12) on or near the Reservation indicate that, during the nearly 3-year period when monthly water-level measurements were made, water levels in the aquifer varied by less than 2 feet. The hydrograph for well 148-093-04CAB 1 indicates a slightly increasing water level, and the hydrograph for well 153-094-23CCC3 indicates a decreasing water level. Data from the four wells indicate no spatially systematic trend in the variability of hydraulic head in the aquifer.

In the upland part of the Reservation, the hydraulic head in the Tongue River aquifer is lower than the hydraulic head in the overlying Sentinel Butte aquifer, possibly indicating that leakage from the Sentinel Butte aquifer contributes recharge to the Tongue River aquifer. The hydraulic head in the Tongue River aquifer also is lower than the hydraulic head in the underlying Fox Hills-Hell Creek aquifer over most of the Reservation, indicating an upward hydraulic gradient that also may contribute recharge to the Tongue River aquifer. Discharge from the Tongue River aquifer is by lateral movement of water to adjacent areas, base flow into streams, and well discharge.

A statistical summary of selected water-quality data for the Tongue River aquifer is given in table 4 . The data pertain to samples collected from 52 wells completed in the aquifer during 1952-92. If more than one sample was collected from a well, only the most recent sample was used in the summary. Water in the aquifer varies from a sodium bicarbonate type to a mixed calcium magnesium sodium sulfate type (fig. 13). Dissolved-solids concentrations ranged from 817 to 4,660 milligrams per liter and had a median of 1,930 milligrams per liter. Dissolved-solids concentrations in at least half of the samples collected from the aquifer exceeded the secondary maximum contaminant level of 500 milligrams per liter (table 2). The median sulfate concentration and the maximum iron and manganese concentrations also exceeded the secondary maximum contaminant levels.

The sodium hazard for water from the Tongue River aquifer, as indicated by the sodium adsorption ratio (table 4), generally is very high (fig. 10). The salinity hazard, as indicated by the specific-

conductance value, also is very high. The combination of these two hazards indicates that water from the Tongue River aquifer generally is unsuitable for irrigation.

\section{Sentinel Butte}

The Sentinel Butte aquifer underlies all of the Reservation except where the aquifer is absent because of erosion (area shown as Tongue River Member in figure 2). The aquifer is composed mainly of 


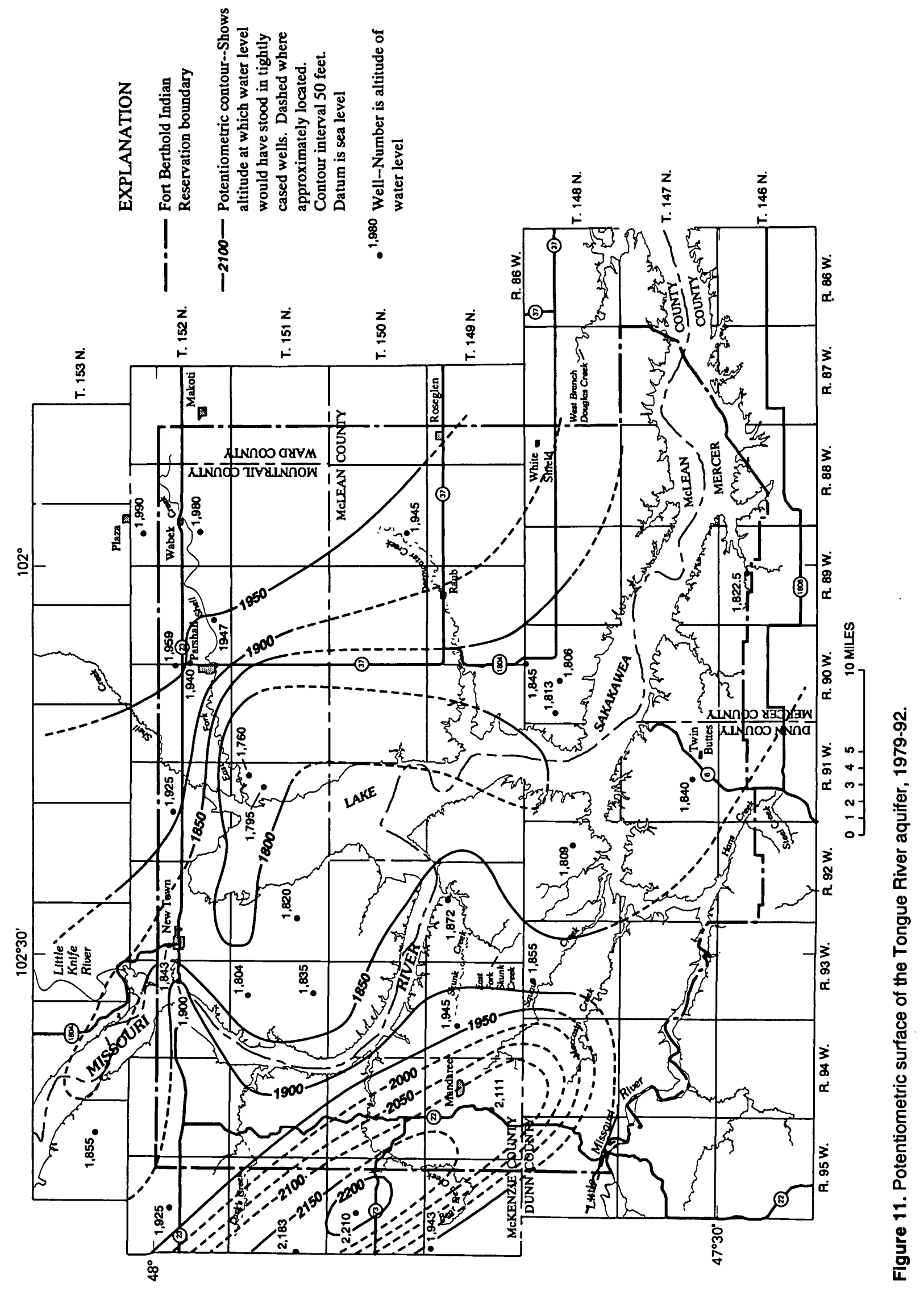



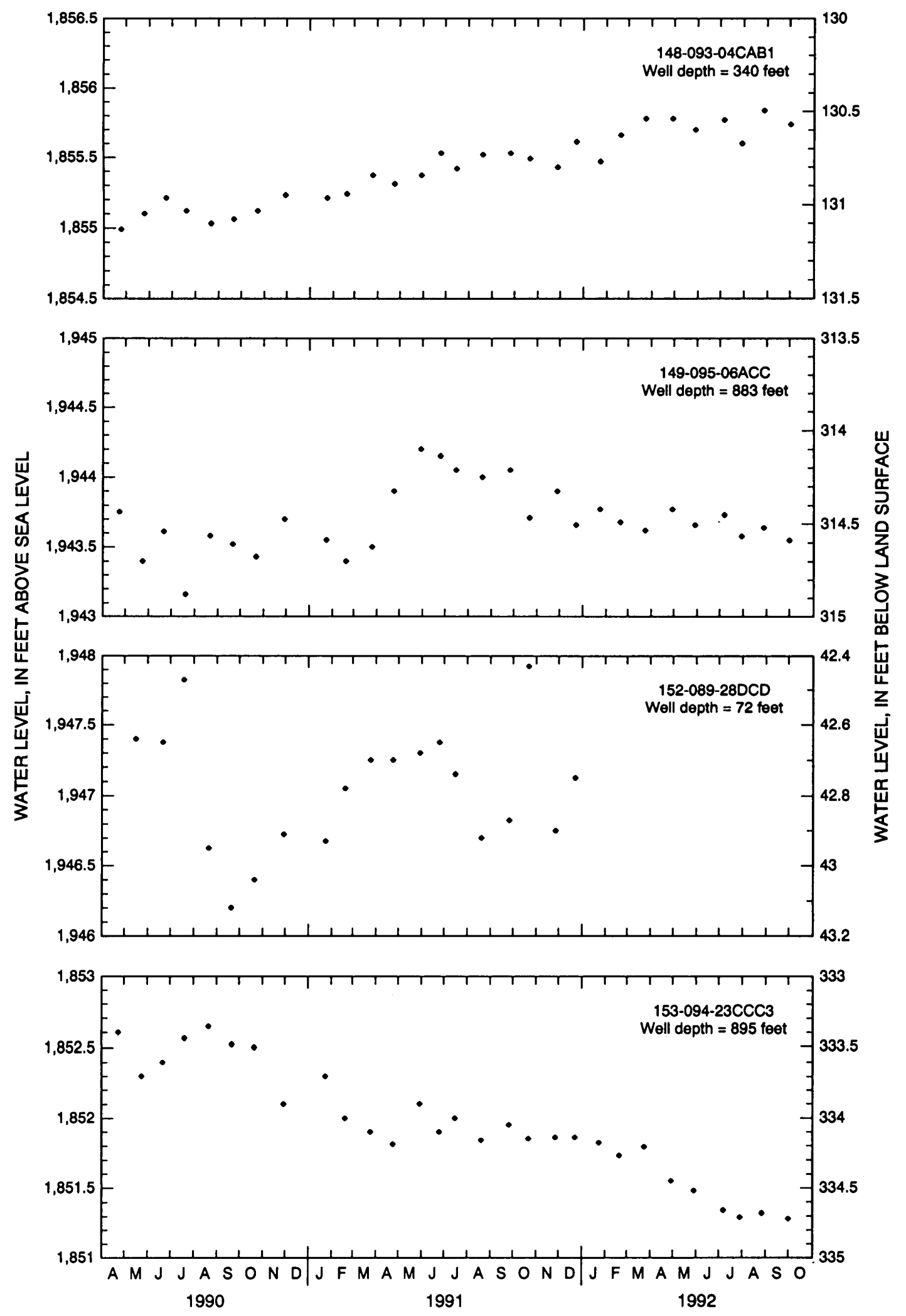

Figure 12. Water levels in wells completed in the Tongue River aquifer, April 1990 through October 1992. 
interbedded claystones, siltstones, shale, fractured lignite, and poorly consolidated sandstone. Numerous factors, including the clay content of sandstone, the degree of lignite fracture, and the lateral extent and thickness of the sandstone or lignite beds, cause large spatial variability in well yield and water quality. The sandstone beds are composed mainly of fine sand interbedded in a matrix of clay and silt and range in thickness from a few feet to about 120 feet. The sandstone beds occur at depths ranging from 10 to 400 feet below land surface. The lignite beds, which generally are limited in lateral extent and occur randomly throughout the entire aquifer, range from less than 1 foot to as much as 20 feet in thickness. The lignite beds are more abundant in the upper part of the aquifer than in the lower part. The upper part of the aquifer has been eroded extensively, however, and remains mostly in the Dunn County and Mercer County parts of the Reservation.

Table 4. Statistical summary of selected water-quality data for the Tongue River aquifer, 1952-92 $\left[\mu \mathrm{S} / \mathrm{cm}\right.$, microsiemens per centimeter; ${ }^{\circ} \mathrm{C}$, degrees Celsius; --, not available; $\mathrm{mg} / \mathrm{L}$, milligrams per liter; <, less than; $\mu \mathrm{g} / \mathrm{L}$, micrograms per liter]

\begin{tabular}{|c|c|c|c|c|c|}
\hline $\begin{array}{l}\text { Physical property or } \\
\text { chemical constituent }\end{array}$ & $\begin{array}{l}\text { Number of } \\
\text { samples }\end{array}$ & Maximum & Minimum & Mean & Median \\
\hline Specific conductance, field $\left(\mu \mathrm{S} / \mathrm{cm}\right.$ at $\left.25^{\circ} \mathrm{C}\right)$ & 51 & 6,270 & 1,280 & 3,070 & 2,950 \\
\hline $\mathrm{pH}$, field (standard units) & 52 & 9.1 & 6.7 & -- & 8.2 \\
\hline Hardness $\left(\mathrm{mg} / \mathrm{L}\right.$ as $\left.\mathrm{CaCO}_{3}\right)$ & 52 & 1,700 & 4 & 140 & 24 \\
\hline Calcium, dissolved (mg/L) & 51 & 460 & 1.0 & 34 & 4.6 \\
\hline Magnesium, dissolved (mg/L) & 51 & 140 & 0.2 & 14 & 2.6 \\
\hline Sodium, dissolved (mg/L) & 51 & 1,600 & 140 & 744 & 750 \\
\hline Sodium adsorption ratio & 51 & 110 & 2.0 & 65 & 71 \\
\hline Potassium, dissolved $(\mathrm{mg} / \mathrm{L})$ & 51 & 11 & 1.0 & 4.3 & 3.5 \\
\hline Bicarbonate, field, total $\left(\mathrm{mg} / \mathrm{L}\right.$ as $\left.\mathrm{CaCO}_{3}\right)$ & 21 & 2,400 & 650 & 1,360 & 1,150 \\
\hline Alkalinity, lab, total $\left(\mathrm{mg} / \mathrm{L}\right.$ as $\left.\mathrm{CaCO}_{3}\right)$ & 30 & 2,080 & 423 & 1,120 & 978 \\
\hline Sulfate, dissolved (mg/L) & 51 & 2,300 & $<0.1$ & 580 & 410 \\
\hline Chloride, dissolved (mg/L) & 52 & 210 & 1.6 & 44 & 21 \\
\hline Fluoride, dissolved (mg/L) & 51 & 8.4 & 0.2 & 1.7 & 1.4 \\
\hline Silica, dissolved $(\mathrm{mg} / \mathrm{L})$ & 51 & 30 & 3.7 & 13 & 12 \\
\hline Dissolved solids, sum of constituents $(\mathrm{mg} / \mathrm{L})$ & 47 & 4,660 & 817 & 2,110 & 1,930 \\
\hline Nitrate, dissolved (mg/L as N) & 13 & 5.9 & 0.11 & 0.70 & 0.23 \\
\hline Boron, dissolved $(\mu \mathrm{g} / \mathrm{L})$ & 36 & 3,700 & $<10$ & 470 & 360 \\
\hline Iron, dissolved $(\mu \mathrm{g} / \mathrm{L})$ & 47 & 7,800 & $<10$ & 880 & 150 \\
\hline Manganese, dissolved $(\mu \mathrm{g} / \mathrm{L})$ & 41 & 8,400 & $<3$ & 270 & 20 \\
\hline Strontium, dissolved $(\mu \mathrm{g} / \mathrm{L})$ & 14 & 4,200 & 55 & 660 & 180 \\
\hline
\end{tabular}

Hydraulic properties of the Sentinel Butte aquifer were determined in previous studies. Armstrong (1971) indicated that specific capacity in well 151-090-36DDA, completed in the Sentinel Butte aquifer, is less than 0.5 gallon per minute per foot of drawdown, and transmissivity of the producing interval is less than 134 feet squared per day. Transmissivity at a well completed in sandstone in the Sentinel Butte aquifer near Plaza is about 400 feet squared per day (Armstrong, 1971). According to Klausing (1979), transmissivity at various locations in Dunn County is about 3 feet squared per day, and hydraulic conductivity is less than or equal to 0.5 foot per day. Hydraulic conductivity at well 148-093-04CBD, which is completed in sandstone in the Sentinel Butte aquifer, is 0.06 foot per day, and transmissivity is 
1 foot squared per day (Klausing, 1979). An aquifer test conducted to evaluate properties of a sandstone bed in an area of observation wells at 152-088-04BBBD indicated specific capacity in the Sentinel Butte aquifer is 2.7 gallons per minute per foot of drawdown, transmissivity is 751 feet squared per day, and the storage coefficient is $2 \times 10^{-4}$ (Comeskey, 1989). Yields from wells developed in sandstones in the Sentinel Butte aquifer may range from about 1 to 100 gallons per minute, depending on the extent, thickness, and hydraulic conductivity of the individual producing intervals.

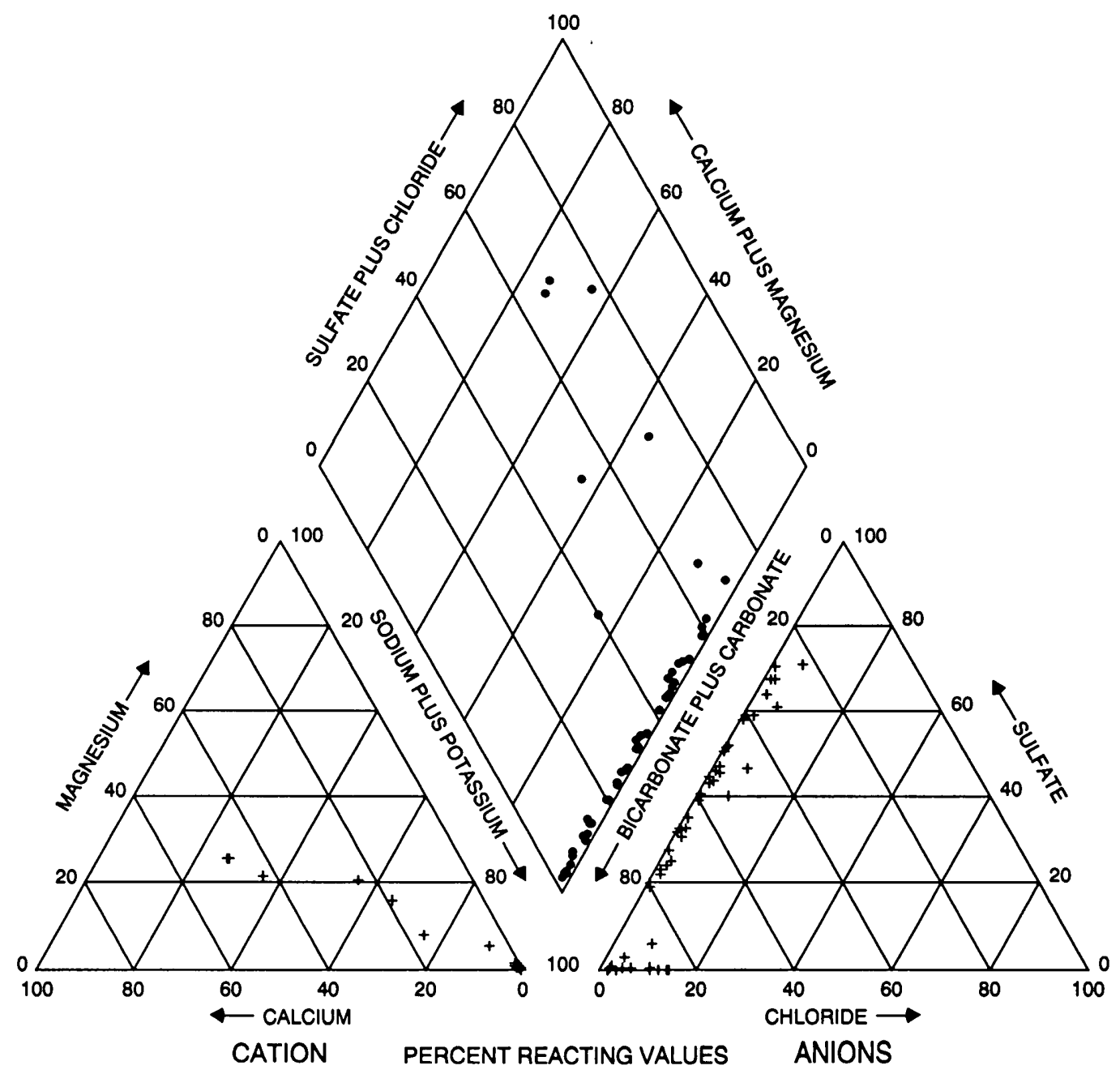

FIgure 13. Major-ion composition of water in the Tongue River aquifer.

Hydraulic properties of two lignite beds in the Sentinel Butte aquifer were determined from well 145094-26AAAl (Klausing, 1979). The upper lignite bed has a transmissivity of 19,500 feet squared per day, a storage coefficient of 0.007 , a specific capacity of 68 gallons per minute per foot of drawdown, and a yield of 100 gallons per minute. The lower lignite bed has a transmissivity of 750 feet squared per day, a storage coefficient of 0.0002 , a specific capacity of 0.9 gallon per minute per foot of drawdown, and a yield of 1 gallon per minute. The hydraulic conductivity of lignite beds is related to the frequency and size of fracturing and bedding partings. When material overlying lignite beds is removed through erosion, the decrease in overburden pressure causes an expansion and subsequent fracturing of the lignite. Shallow 
lignite beds generally have larger hydraulic conductivities than deep lignite beds because of the inverse relation between depth and bedding partings.

Lignite beds in the Sentinel Butte aquifer yield water only locally. Yields from lignite beds are highly variable and depend on the size and extent of fractures, the depth of burial, the transmissivity of adjacent rock, and the proximity of lignite beds to their outcrops. Test drilling was conducted at several locations where lignite beds crop out on valley walls. The lignite beds did not yield water to the test holes, and drilling generally was difficult because of the loss of drilling fluid into the dry lignite beds. Based on an areal extent of 914 square miles, an average cumulative thickness of $100 \mathrm{feet}$, and an assumed porosity of 30 percent, the volume of water stored in the Sentinel Butte aquifer is about 18 million acre-feet.

Hydrographs of two wells completed in the Sentinel Butte aquifer (fig 14) on or near the Reservation indicate that, during the nearly 3 -year period when monthly water-level measurements were made, water levels in the aquifer were variable. The hydrograph for well 152-088-04BBBD1 indicates the water level rose and fell several times and probably is affected by water withdrawals from municipal wells for Plaza. During the same period, the water level in well 148-093-04CAB2 declined by about 1 foot.

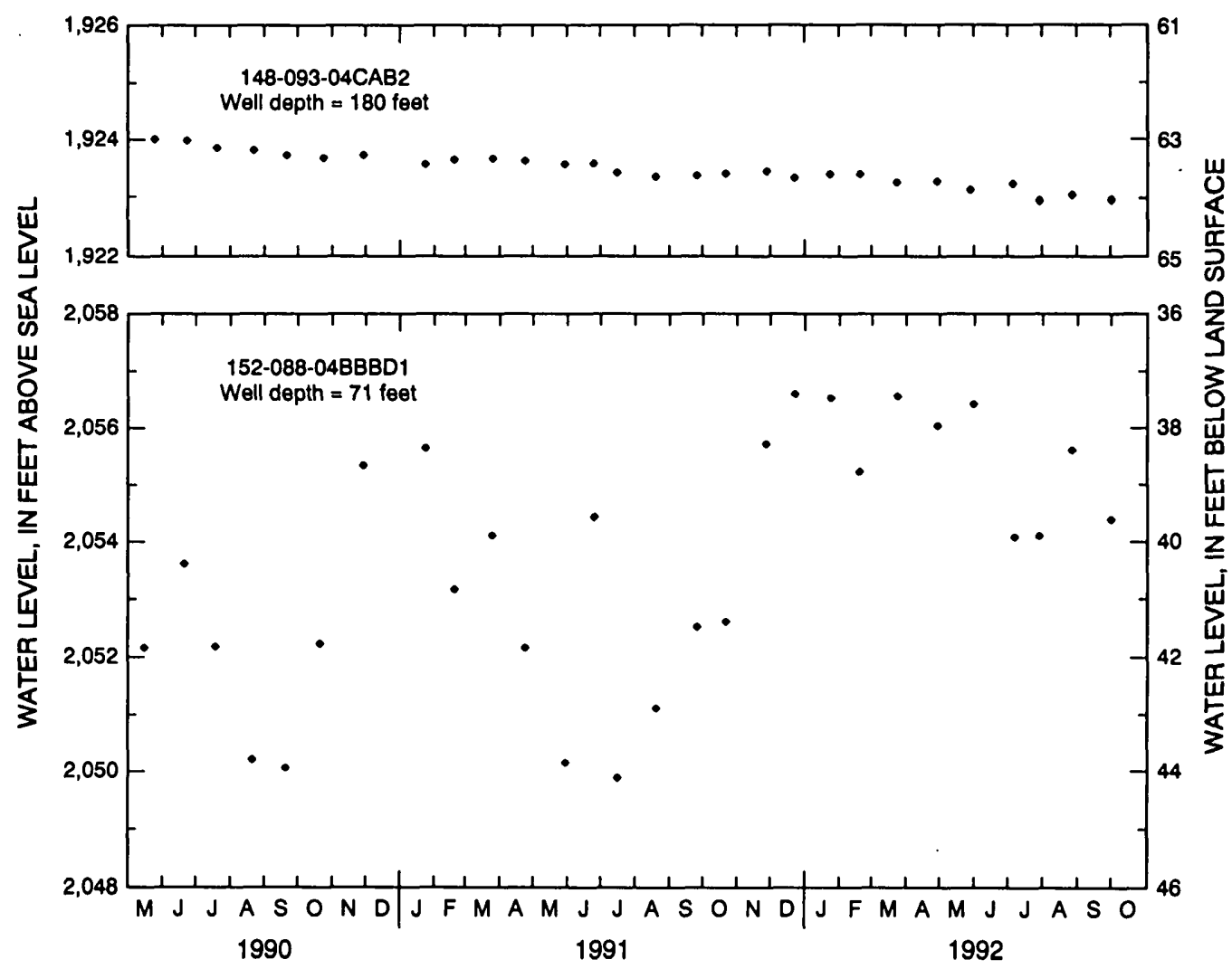

Figure 14. Water levels in wells completed in the Sentinel Butte aquifer, May 1990 through October 1992.

Recharge to the Sentinel Butte aquifer is by infiltration of precipitation. Discharge is by lateral movement of water to adjacent areas, downward seepage into the Tongue River aquifer, seepage into streams and springs, and well pumpage. 
A statistical summary of selected water-quality data for the Sentinel Butte aquifer is given in table 5 . The data pertain to samples collected from 83 wells completed in the aquifer during 1950-92. If more than one sample was collected from a well, only the most recent sample was used in the summary. Water in the aquifer varies from a sodium bicarbonate type to a mixed calcium magnesium sodium sulfate type (fig. 15). Dissolved-solids concentrations ranged from 133 to 4,230 milligrams per liter and had a median of 964 milligrams per liter. Dissolved-solids concentrations in more than half of the samples collected from the aquifer exceeded the secondary maximum contaminant level of 500 milligrams per liter (table 2). The median sulfate and manganese concentrations and the maximum chloride and iron concentrations also exceeded the secondary maximum contaminant levels.

Table 5. Statistical summary of selected water-quality data for the Sentinel Butte aquifer, 1950-92

$\left[\mu \mathrm{S} / \mathrm{cm}\right.$, microsiemens per centimeter; ${ }^{\circ} \mathrm{C}$, degrees Celsius; --, not available; $\mathrm{mg} / \mathrm{L}$, milligrams per liter; $<$, less than; $\mu \mathrm{g} / \mathrm{L}$, micrograms per liter]

\begin{tabular}{|c|c|c|c|c|c|}
\hline $\begin{array}{l}\text { Physical property or } \\
\text { chemical constituent }\end{array}$ & $\begin{array}{l}\text { Number of } \\
\text { samples }\end{array}$ & Maximum & Minimum & Mean & Median \\
\hline Specific conductance, field $\left(\mu \mathrm{S} / \mathrm{cm}\right.$ at $\left.25^{\circ} \mathrm{C}\right)$ & 81 & 5,270 & 174 & 1,850 & 1,460 \\
\hline $\mathrm{pH}$, field (standard units) & 83 & 8.9 & 6.7 & - & 7.7 \\
\hline Hardness $\left(\mathrm{mg} / \mathrm{L}\right.$ as $\left.\mathrm{CaCO}_{3}\right)$ & 83 & 2,500 & 7 & 424 & 310 \\
\hline Calcium, dissolved (mg/L) & 83 & 510 & 1.3 & 89 & 58 \\
\hline Magnesium, dissolved (mg/L) & 83 & 300 & 0.6 & 49 & 37 \\
\hline Sodium, dissolved $(\mathrm{mg} / \mathrm{L})$ & 83 & 1,300 & 3.7 & 317 & 180 \\
\hline Sodium adsorption ratio & 83 & 91 & 0.1 & 14 & 4.0 \\
\hline Potassium, dissolved (mg/L) & 83 & 15 & 1.4 & 5.4 & 5.2 \\
\hline Bicarbonate, field, total $\left(\mathrm{mg} / \mathrm{L}\right.$ as $\left.\mathrm{CaCO}_{3}\right)$ & 60 & 1,510 & 53 & 573 & 490 \\
\hline Alkalinity, field, total $\left(\mathrm{mg} / \mathrm{L}\right.$ as $\left.\mathrm{CaCO}_{3}\right)$ & 45 & 1,380 & 43 & 452 & 369 \\
\hline Sulfate, dissolved (mg/L) & 79 & 2,400 & 11 & 526 & 300 \\
\hline Chloride, dissolved (mg/L) & 79 & 700 & $<1.0$ & 22 & 5.8 \\
\hline Fluoride, dissolved (mg/L) & 78 & 2.8 & 0.1 & 0.5 & 0.3 \\
\hline Silica, dissolved (mg/L) & 83 & 27 & 4.7 & 16 & 16 \\
\hline Dissolved solids, sum of constituents (mg/L) & 79 & 4,230 & 133 & 1,300 & 964 \\
\hline Boron, dissolved $(\mu \mathrm{g} / \mathrm{L})$ & 71 & 1,200 & $<10$ & 330 & 300 \\
\hline Iron, dissolved $(\mu \mathrm{g} / \mathrm{L})$ & 81 & 14,000 & $<10$ & 1,100 & 280 \\
\hline Manganese, dissolved $(\mu \mathrm{g} / \mathrm{L})$ & 64 & 2,800 & $<10$ & 320 & 140 \\
\hline Strontium, dissolved $(\mu \mathrm{g} / \mathrm{L})$ & 15 & 1,800 & 120 & 800 & 550 \\
\hline
\end{tabular}

The sodium hazard for water from the Sentinel Butte aquifer, as indicated by the sodium adsorption ratio (table 5), generally is low (fig. 10). The salinity hazard, as indicated by the specific-conductance value, generally is high. The combination of these two hazards indicates that water from the Sentinel Butte aquifer is suitable for irrigation on soils that have high permeability. 


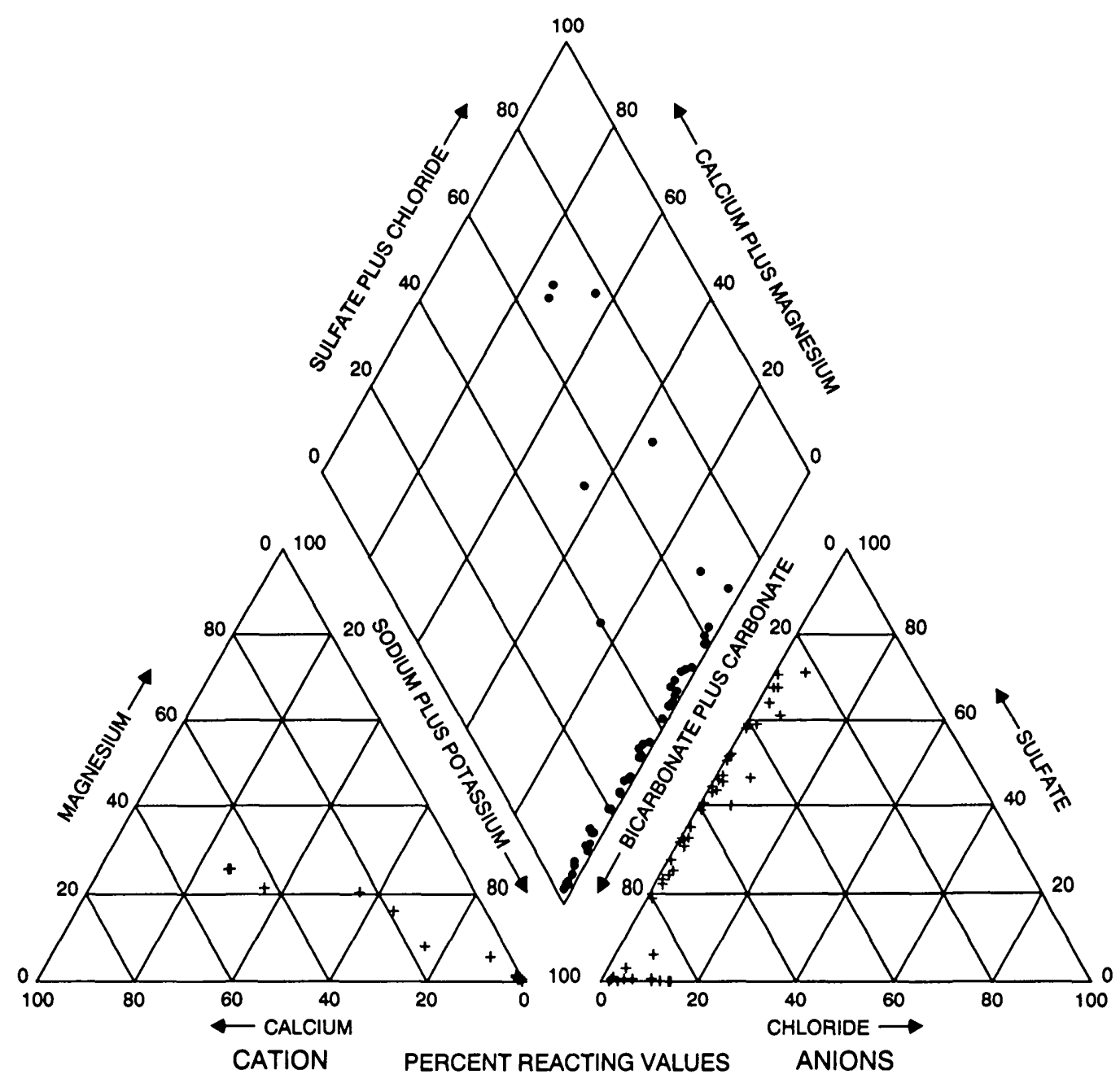

Figure 15. Major-ion composition of water in the Sentinel Butte aquifer.

\section{Buried-Valley Aquifers}

\section{East Fork Shell Creek}

The East Fork Shell Creek aquifer (also referred to as the Parshall aquifer) and the Shell Creek aquifer (fig. 16) consist of glaciofluvial sediments deposited in buried valleys that underlie the major drainages of the area near Parshall. The two aquifers are in close proximity and are separated by a pronounced bedrock high near well 152-090-11DDD1 (fig. 17).

The East Fork Shell Creek aquifer underlies East Fork Shell Creek and Parshall and has an areal extent of about 12 square miles and a width of about 1 mile. The aquifer is composed of sand and gravel lenses that vary in thickness, have unknown lateral extent, and are surrounded by less-permeable till. The sand and gravel lenses occur at various depths down to 100 feet. The aquifer is underlain directly by the Tongue River Member, which was eroded into a rugged topography before or during glaciation.

According to Armstrong (1971), the specific capacity of well 152-090-25DBC2 in the East Fork Shell Creek aquifer is 11 gallons per minute per foot of drawdown, indicating a transmissivity of about 


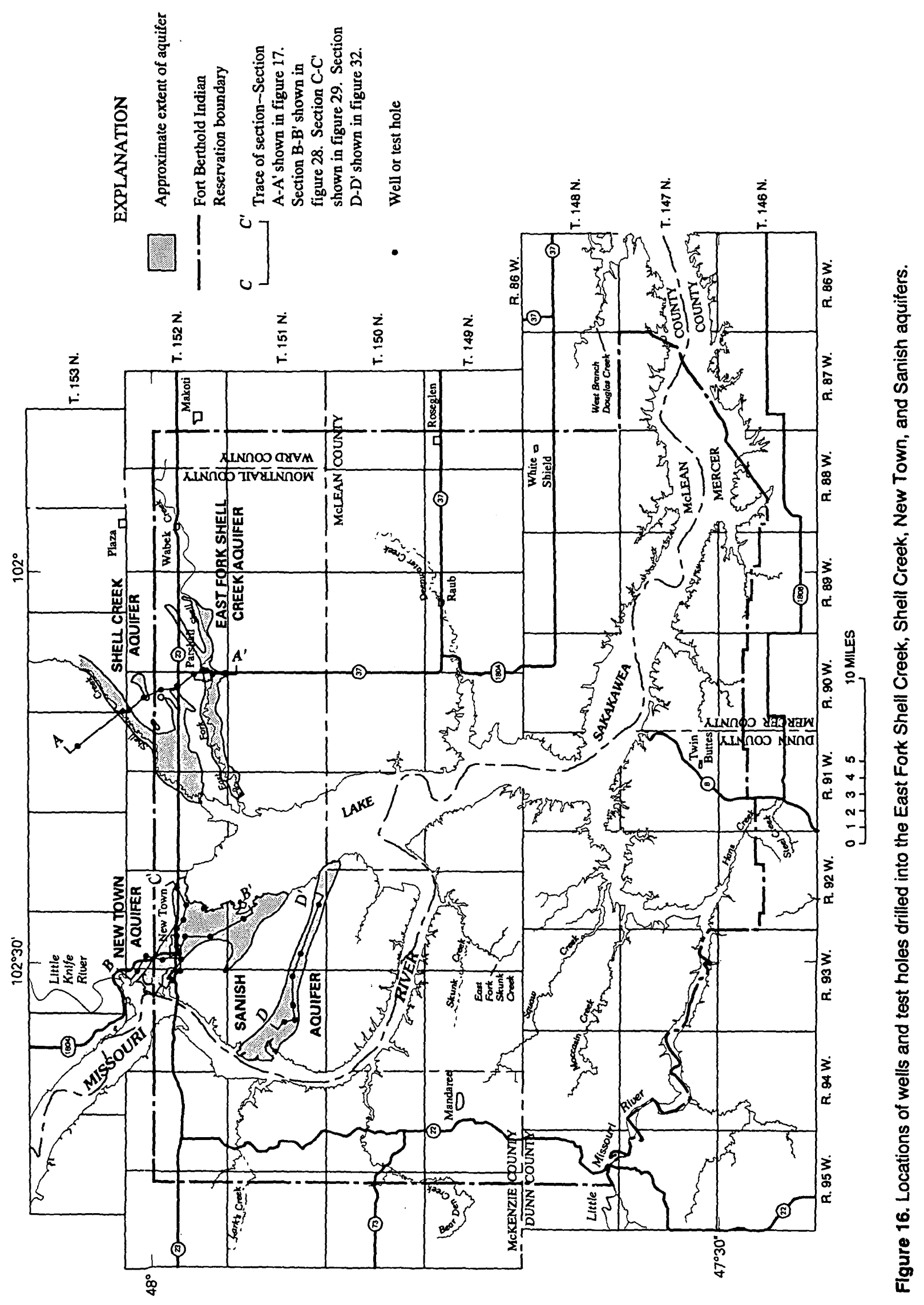




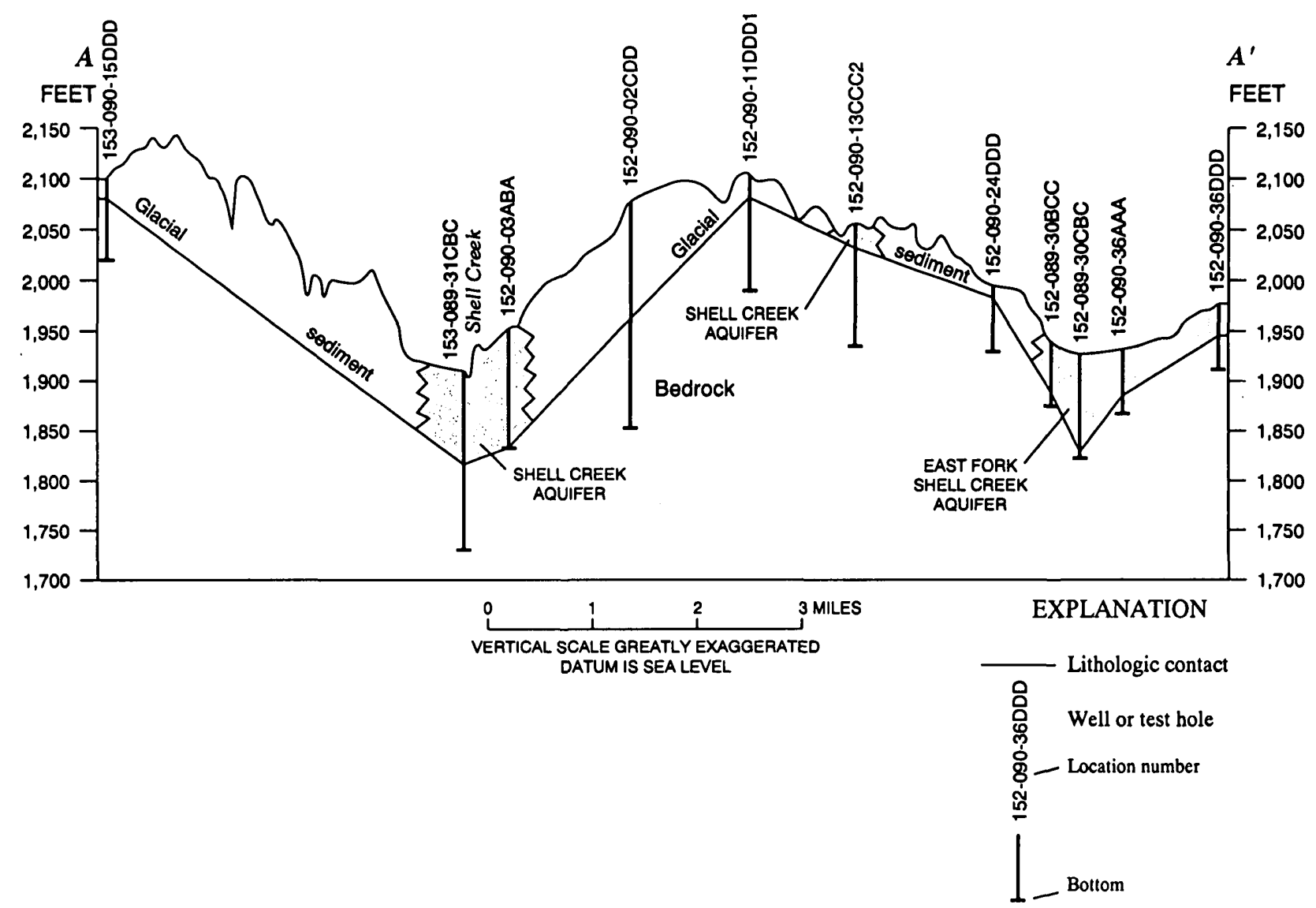

Figure 17. Geologic section A-A' through the East Fork Shell Creek and Shell Creek aquifers and altitude of the underlying bedrock (trace of section shown in figure 16).

2,950 feet squared per day. Schmid and Ziegler (1962) determined a similar transmissivity of 3,350 feet squared per day and a storage coefficient of 0.0043 at well 152-090-25DBC1. According to Schmid and Ziegler (1962), the East Fork Shell Creek aquifer is confined near Parshall, and some of the lenses that comprise the aquifer are hydraulically connected. Based on an areal extent of 12 square miles, an average cumulative thickness of 20 feet, and an assumed porosity of 30 percent, the volume of water stored in the East Fork Shell Creek aquifer is about 46,000 acre-feet.

A hydrograph of well 152-089-23CCC completed in the East Fork Shell Creek aquifer (fig. 18) indicates that, during the nearly 3 -year period when monthly water-level measurements were made, water levels in the aquifer were cyclic. A hydrograph of well 152-089-28DCD (fig. 12), a nearby well completed in the Tongue River aquifer, indicates the same type of cyclical variation but with a smaller amplitude.

A statistical summary of selected water-quality data for the East Fork Shell Creek aquifer is given in table 6. The data pertain to samples collected from five wells completed in the aquifer during 1962-90. If more than one sample was collected from a well, only the most recent sample was used in the summary. Generally, water in the aquifer is a sodium sulfate bicarbonate type (fig. 19). Dissolved-solids concentrations ranged from 2,470 to 4,440 milligrams per liter and had a median of 2,980 milligrams per liter. Dissolved-solids concentrations in all samples collected from the aquifer exceeded the secondary maximum contaminant level of 500 milligrams per liter (table 2). The minimum sulfate and manganese concentrations and the median iron concentration also exceeded the secondary maximum contaminant levels. 


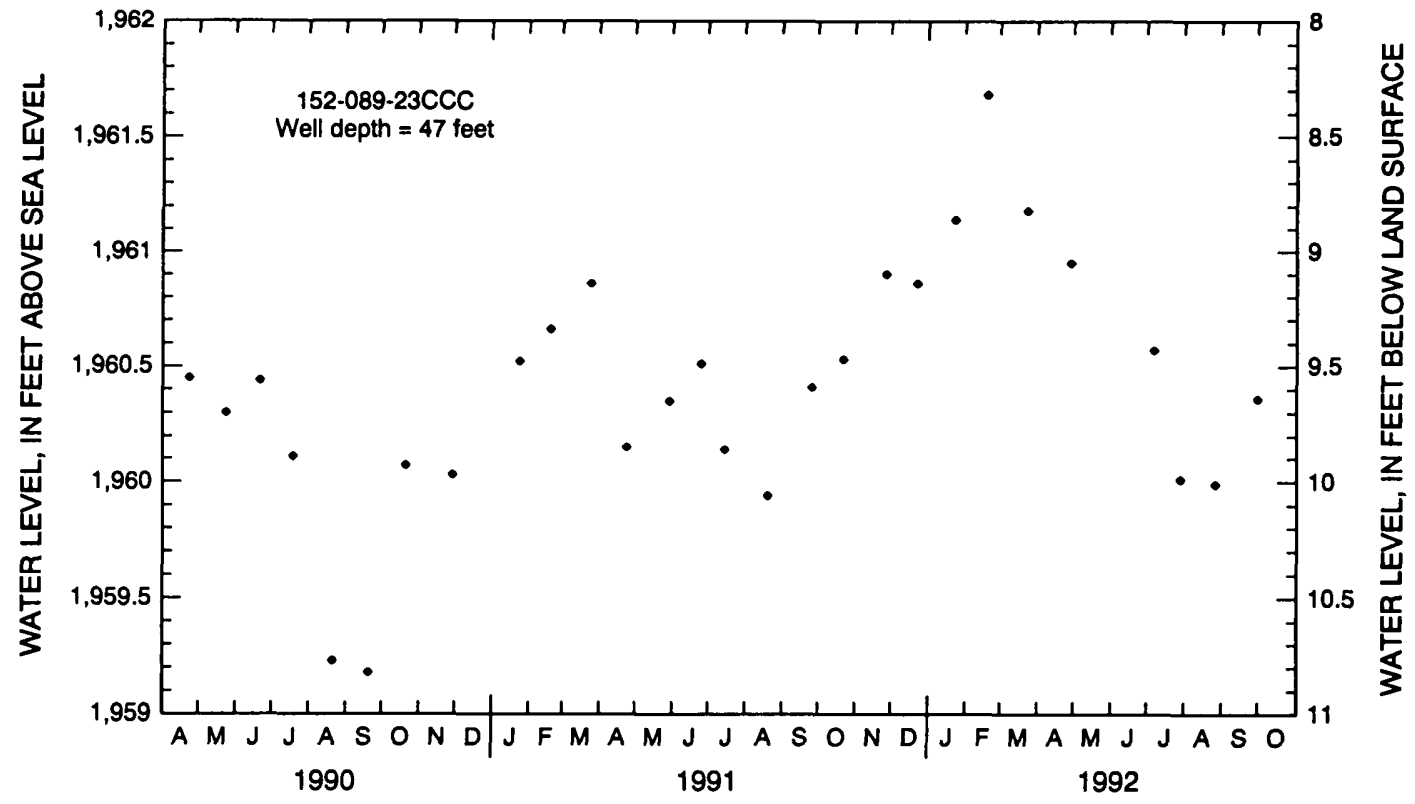

Figure 18. Water level in a well completed in the East Fork Shell Creek aquifer, April 1990 through October 1992.

Table 6. Statistical summary of selected water-quality data for the East Fork Shell Creek aquifer, 1962-90

$\left[\mu \mathrm{S} / \mathrm{cm}\right.$, microsiemens per centimeter; ${ }^{\circ} \mathrm{C}$, degrees Celsius; --, not available; $\mathrm{mg} / \mathrm{L}$, milligrams per liter; $\mu \mathrm{g} / \mathrm{L}$, micrograms per liter; <, less than]

\begin{tabular}{|c|c|c|c|c|c|}
\hline $\begin{array}{l}\text { Physical property or } \\
\text { chemical constituent }\end{array}$ & $\begin{array}{l}\text { Number of } \\
\text { samples }\end{array}$ & Maximum & Minimum & Mean & Median \\
\hline Specific conductance, field $\left(\mu \mathrm{S} / \mathrm{cm}\right.$ at $\left.25^{\circ} \mathrm{C}\right)$ & 4 & 5,190 & 2,320 & 3,870 & 3,980 \\
\hline $\mathrm{pH}$, field (standard units) & 4 & 8.7 & 7.5 & -. & 8.0 \\
\hline Hardness $\left(\mathrm{mg} / \mathrm{L}\right.$ as $\left.\mathrm{CaCO}_{3}\right)$ & 5 & 3,300 & 140 & 248 & 260 \\
\hline Calcium, dissolved $(\mathrm{mg} / \mathrm{L})$ & 4 & 780 & 34 & 231 & 55 \\
\hline Magnesium, dissolved (mg/L) & 4 & 340 & 13 & 102 & 28 \\
\hline Sodium, dissolved $(\mathrm{mg} / \mathrm{L})$ & 4 & 1,000 & 280 & 735 & 830 \\
\hline Sodium adsorption ratio & 4 & 31 & 2.0 & 21 & 26 \\
\hline Potassium, dissolved (mg/L) & 4 & 17 & 5.5 & 9.8 & 8.3 \\
\hline Bicarbonate, field $\left(\mathrm{mg} / \mathrm{L}\right.$ as $\left.\mathrm{CaCO}_{3}\right)$ & 4 & 1,170 & 650 & 948 & 985 \\
\hline Alkalinity, field, total $\left(\mathrm{mg} / \mathrm{L}\right.$ as $\left.\mathrm{CaCO}_{3}\right)$ & 3 & 959 & 752 & -- & 902 \\
\hline Sulfate, dissolved (mg/L) & 5 & 2,500 & 960 & 1,450 & 1,100 \\
\hline Chloride, dissolved (mg/L) & 4 & 200 & 7.5 & 67 & 30 \\
\hline Fluoride, dissolved (mg/L) & 4 & 1.3 & 0.2 & 0.6 & 0.6 \\
\hline Silica, dissolved $(\mathrm{mg} / \mathrm{L})$ & 4 & 29 & 21 & 25 & 24 \\
\hline Dissolved solids, sum of constituents (mg/L) & 4 & 4,440 & 2,470 & 3,220 & 2,980 \\
\hline Nitrate, dissolved ( $\mathrm{mg} / \mathrm{L}$ as $\mathrm{N}$ ) & 2 & 0.38 & 0.23 & -- & -. \\
\hline Boron, dissolved $(\mu \mathrm{g} / \mathrm{L})$ & 4 & 760 & 190 & 430 & 390 \\
\hline Iron, dissolved $(\mu \mathrm{g} / \mathrm{L})$ & 4 & 1,700 & $<10$ & 880 & 910 \\
\hline Manganese, dissolved $(\mu \mathrm{g} / \mathrm{L})$ & 3 & 80 & 51 & -- & 80 \\
\hline Strontium, dissolved $(\mu \mathrm{g} / \mathrm{L})$ & 1 & 790 & -- & -- & -- \\
\hline
\end{tabular}




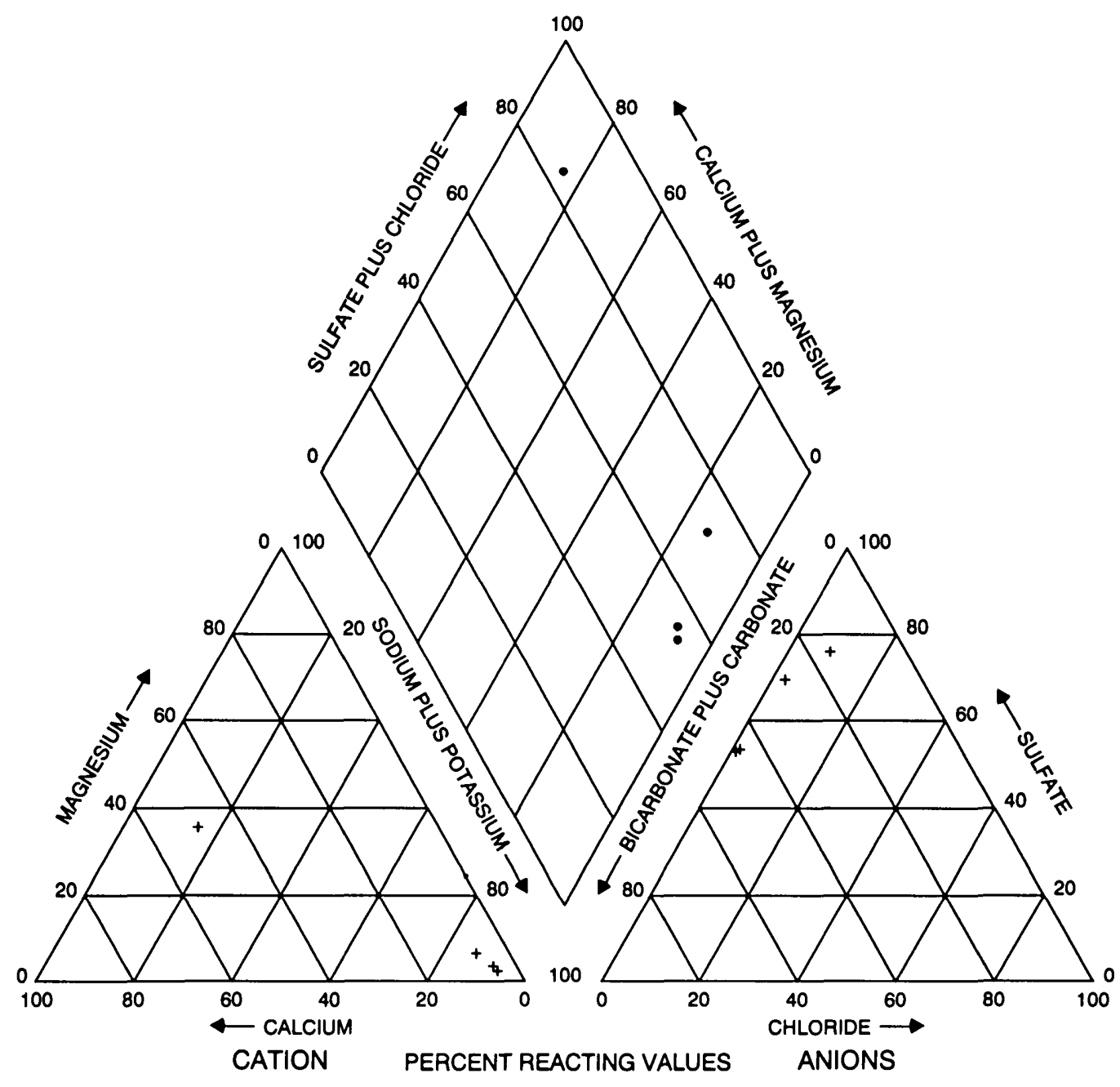

Flgure 19. Major-ion composition of water in the East Fork Shell Creek aquifer.

The sodium hazard for water from the East Fork Shell Creek aquifer, as indicated by the sodium adsorption ratio (table 6), generally is high (fig. 10). The salinity hazard, as indicated by the specific-conductance value, generally is very high. The combination of these two hazards indicates that water from the East Fork Shell Creek aquifer is unsuitable for irrigation.

\section{Shell Creek}

The Shell Creek aquifer lies within a broad, deep buried valley northwest of Parshall (fig. 16). The aquifer has an areal extent of about 10 square miles within the Reservation and ranges from 0.75 to 2 miles in width. Apparent similarities in the geometry, geology, and origin of the East Fork Shell Creek and Shell Creek aquifers indicate that descriptions of the East Fork Shell Creek aquifer (Schmid and Ziegler, 1962) generally are applicable to the Shell Creek aquifer.

The Shell Creek aquifer is composed of sand and gravel lenses that vary in thickness, have unknown lateral extent, and are surrounded by till. Limited data indicate aquifer thickness is as much as 100 feet in the Shell Creek buried valley. Within the Reservation, wells completed in the Shell Creek aquifer are 
between 12 and 80 feet deep. Based on an areal extent of 10 square miles, an average cumulative thickness of 20 feet, and an assumed porosity of 30 percent, the volume of water stored in the Shell Creek aquifer on the Reservation is about 38,000 acre-feet.

A statistical summary of selected water-quality data for the Shell Creek aquifer is given in table 7. The data pertain to samples collected from four wells completed in the aquifer during 1977-90. If more than one sample was collected from a well, only the most recent sample was used in the summary.

Generally, water in the aquifer is a sodium bicarbonate sulfate type (fig. 20). Dissolved-solids concentrations ranged from 757 to 2,030 milligrams per liter and had a median of 1,560 milligrams per liter. Dissolved-solids concentrations in all samples collected from the aquifer exceeded the secondary maximum contaminant level of 500 milligrams per liter (table 2). The median sulfate concentration and the minimum iron and manganese concentrations also exceeded the secondary maximum contaminant levels.

Table 7. Statistical summary of selected water-quality data for the Shell Creek aquifer, 1977-90

$\left[\mu \mathrm{S} / \mathrm{cm}\right.$, microsiemens per centimeter; ${ }^{\circ} \mathrm{C}$, degrees Celsius; --, not available; $\mathrm{mg} / \mathrm{L}$, milligrams per liter; <, less than; $\mu \mathrm{g} / \mathrm{L}$, micrograms per liter]

\begin{tabular}{|c|c|c|c|c|c|}
\hline $\begin{array}{l}\text { Physical property or } \\
\text { chemical constituent }\end{array}$ & $\begin{array}{l}\text { Number of } \\
\text { samples }\end{array}$ & Maximum & Minimum & Mean & Median \\
\hline Specific conductance, field $\left(\mu \mathrm{S} / \mathrm{cm}\right.$ at $\left.25^{\circ} \mathrm{C}\right)$ & 4 & 2,400 & 1,150 & 2,020 & 2,260 \\
\hline pH, field (standard units) & 4 & 8.4 & 7.3 & -- & 8.2 \\
\hline Hardness $\left(\mathrm{mg} / \mathrm{L}\right.$ as $\left.\mathrm{CaCO}_{3}\right)$ & 4 & 300 & 180 & 250 & 260 \\
\hline Calcium, dissolved $(\mathrm{mg} / \mathrm{L})$ & 4 & 62 & 46 & 54 & 55 \\
\hline Magnesium, dissolved (mg/L) & 4 & 35 & 17 & 27 & 28 \\
\hline Sodium, dissolved $(\mathrm{mg} / \mathrm{L})$ & 4 & 660 & 180 & 440 & 470 \\
\hline Sodium adsorption ratio & 4 & 21 & 5.0 & 13 & 12 \\
\hline Potassium, dissolved (mg/L) & 4 & 8.0 & 3.5 & 5.1 & 4.5 \\
\hline Bicarbonate, field $\left(\mathrm{mg} / \mathrm{L}\right.$ as $\left.\mathrm{CaCO}_{3}\right)$ & 3 & 890 & 635 & -- & 790 \\
\hline Alkalinity, field (mg/L as $\left.\mathrm{CaCO}_{3}\right)$ & 3 & 745 & 520 & -- & 668 \\
\hline Sulfate, dissolved (mg/L) & 4 & 780 & 140 & 490 & 520 \\
\hline Chloride, dissolved (mg/L) & 4 & 12 & 4.8 & 9.7 & 11 \\
\hline Fluoride, dissolved (mg/L) & 4 & 0.6 & $<0.1$ & 0.3 & 0.2 \\
\hline Silica, dissolved $(\mathrm{mg} / \mathrm{L})$ & 4 & 30 & 27 & 28 & 28 \\
\hline Dissolved solids, sum of constituents (mg/L) & 4 & 2,030 & 757 & 1,470 & 1,560 \\
\hline Nitrate, dissolved ( $\mathrm{mg} / \mathrm{L}$ as $\mathrm{N})$ & 3 & 0.23 & 0.23 & -- & 0.23 \\
\hline Boron, dissolved $(\mu \mathrm{g} / \mathrm{L})$ & 4 & 430 & 140 & 290 & 290 \\
\hline Iron, dissolved $(\mu \mathrm{g} / \mathrm{L})$ & 4 & 1,300 & 400 & 700 & 540 \\
\hline Manganese, dissolved $(\mu \mathrm{g} / \mathrm{L})$ & 4 & 380 & 140 & 220 & 190 \\
\hline Strontium, dissolved $(\mu \mathrm{g} / \mathrm{L})$ & 1 & 410 & -- & -- & -- \\
\hline
\end{tabular}

The sodium hazard for water from the Shell Creek aquifer, as indicated by the sodium adsorption ratio (table 7), generally is medium (fig. 10). The salinity hazard, as indicated by the specific-conductance value, generally is very high. The combination of these two hazards indicates that water from the Shell Creek aquifer is unsuitable for irrigation except for special soil-drainage conditions and crop types. 


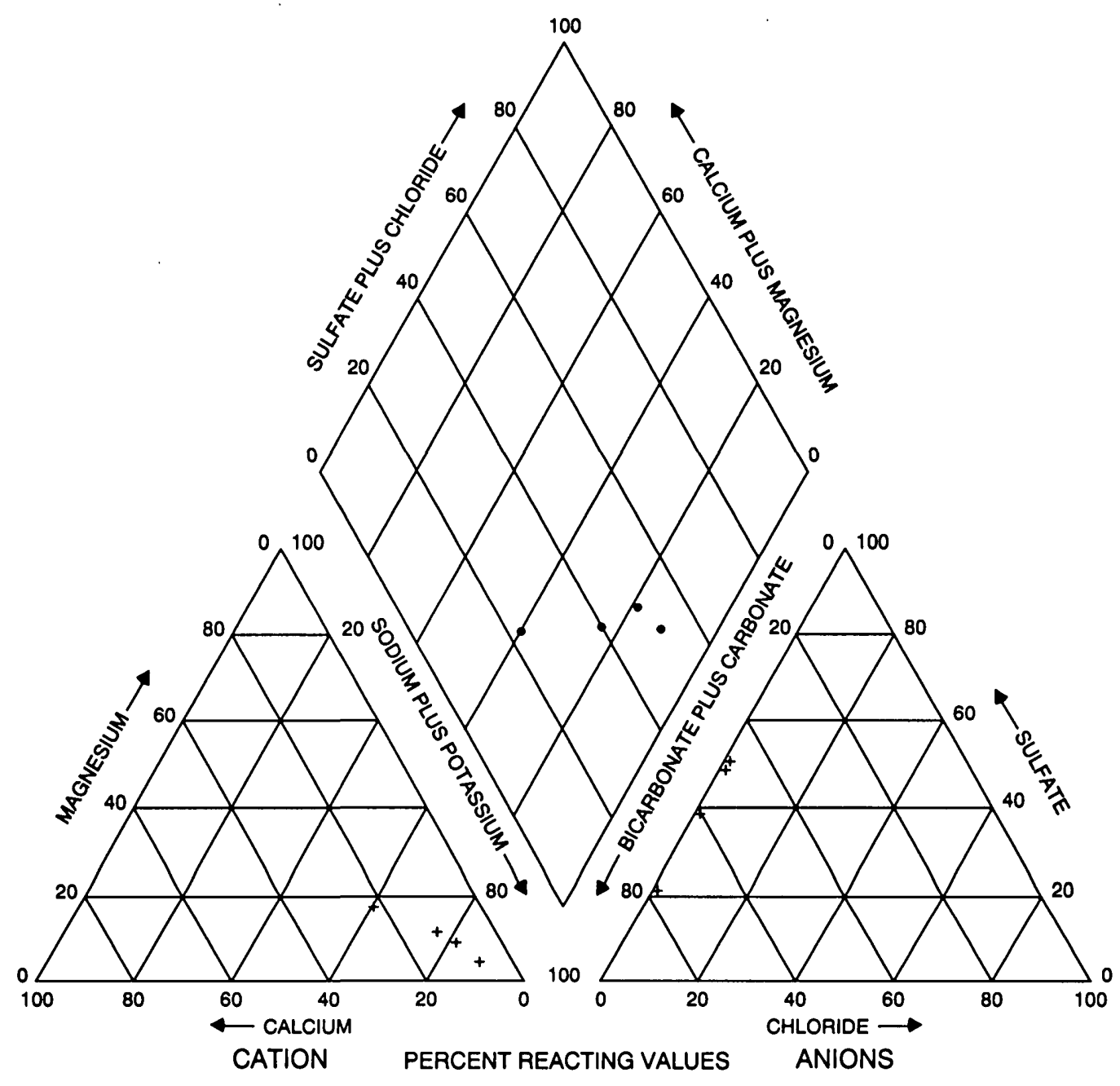

Figure 20. Major-ion composition of water in the Shell Creek aquifer.

\section{White Shield}

The White Shield aquifer lies within a buried valley (fig. 4) and has an areal extent of about 48 square miles within the Reservation. The aquifer is composed of interbedded, very fine to coarse sand and fine to coarse gravel and is overlain and confined by till. Thickness of the aquifer ranges from 18 to 226 feet and averages about 100 feet (Klausing, 1974). Coarse gravels occur in 200 -foot-thick sequences in two areas of the aquifer and in a 120-foot-thick sequence at the northwestern end of the aquifer (fig. 21).

Hydraulic-head data indicate that the White Shield aquifer is separated into two parts, designated hereinafter as the eastern and western parts, and is not hydraulically connected along its entire length. Numerous glacial advances and retreats caused complex glacial and interglacial crosscutting, which, in turn, caused buried valleys to be divided by younger glacial-lake spillways and resulted in lowtransmissivity barriers between different parts of adjacent buried-valley segments (Shaver and Pusc, 1992). Comprised of till, the transverse hydraulic barriers are narrow, continuous barriers generally aligned roughly perpendicular to the long axes of buried valleys. The boundary between the two parts of the White Shield aquifer is considered to be the ground-water divide, possibly in the form of a transverse hydraulic barrier, shown in figure 4. 


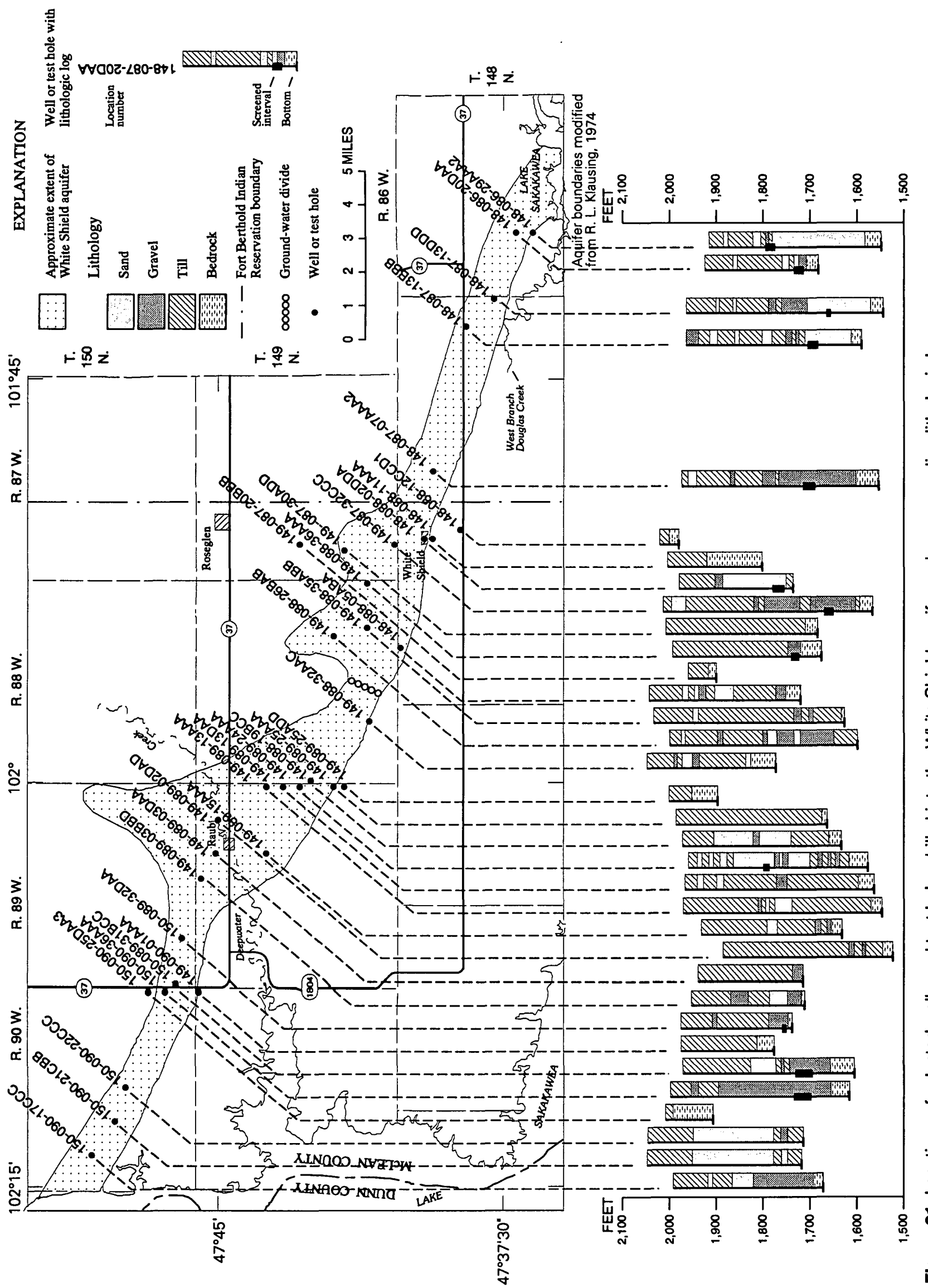

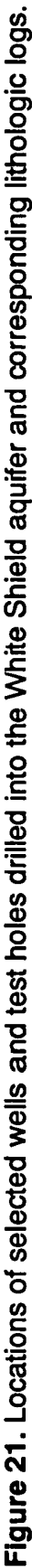


High-accuracy gravity data (Wald and Cates, 1995) were used to help refine the delineation of the White Shield buried valley. The gravity data identified previously undetected paleochannels entering the primary northwest-to-southeast valley from the north. A gravity low (feature A in figure 22) and a subdued low (feature B in figure 22) identified one paleodrainage, and another gravity low (feature $\mathrm{E}$ in figure 22) identified a second paleodrainage that was undefined before the gravity survey and subsequent test drilling.

A structure-contour map showing the altitude of the top of the Fort Union Formation (Tongue River and Sentinel Butte Members) near the White Shield aquifer (fig. 23) was constructed using data obtained during and since completion of the county ground-water studies and information obtained from test drilling based on gravity data. A test hole (149-088-26BAB) drilled at the mouth of the paleodrainage indicated a gravel interval between 220 and 342 feet, demonstrating the effectiveness of using a high-accuracy gravity survey to locate paleodrainages adjacent to buried valleys.

Results of three aquifer tests conducted during 1965-80 indicate variation in aquifer hydraulic properties for the eastern part of the White Shield aquifer. A 140 -foot-thick interval of medium sand and coarse gravel in well 148-087-14BAA, about 6 miles north of Lake Sakakawea and east of the Reservation, had a transmissivity of about 200,000 feet squared per day and a storage coefficient of $6 \times 10^{-4}$ (North Dakota State Water Commission, written commun., 1994). A 43-foot-thick interval of sand and gravel in well 148-088-02DDA had a specific capacity of 16 gallons per minute per foot of drawdown and a transmissivity of about 5,300 feet squared per day (Klausing, 1974). A 214-foot-thick interval of sand and gravel in well 149-087-32CCC had an estimated transmissivity of about 21,000 feet squared per day (Klausing, 1974). Several irrigation wells have been developed in the eastern part of the aquifer, but none occur in the western part of the aquifer. Based on an areal extent of 48 square miles, an average cumulative thickness of 100 feet, and an assumed porosity of 30 percent, the volume of water stored in the White Shield aquifer on the Reservation is about 920,000 acre-feet.

Hydrographs of wells completed about 7.6 miles apart in the eastern part of the aquifer (fig. 24) indicate similar water-level trends (and general resemblance to lake-level trends) from 1970 to 1992. Hydrographs of wells completed in the western part of the aquifer (fig. 25) indicate a net rise in water level during 1970-92 and no relation to lake stage. Water-level data obtained from 10 wells completed in the White Shield aquifer indicate ground water flows to the west in the western part of the aquifer and to the east in the eastern part of the aquifer. Data are insufficient to define the recharge and discharge conditions in the White Shield aquifer.

A statistical summary of selected water-quality data for the eastern and western parts of the White Shield aquifer is given in table 8. The data pertain to samples collected from 9 wells in the eastern part of the aquifer and 11 wells in the western part of the aquifer during 1966-92. If more than one sample was collected from a well, only the most recent sample was used in the summary. Water in both parts of the aquifer varies from a sodium bicarbonate sulfate type to a mixed calcium magnesium sodium bicarbonate sulfate type (figs. 26 and 27). Dissolved-solids concentrations in the eastern part of the aquifer ranged from 853 to 1,480 milligrams per liter and had a median of 898 milligrams per liter, and concentrations in the western part of the aquifer ranged from 513 to 2,340 milligrams per liter and had a median of 1,420 milligrams per liter. Dissolved-solids concentrations in all samples collected from the aquifer exceeded the secondary maximum contaminant level of 500 milligrams per liter (table 2). The median sulfate and iron concentrations in both parts of the aquifer and the maximum manganese concentration in the eastern part of the aquifer and the median manganese concentration in the western part of the aquifer also exceeded the secondary maximum contaminant levels. 


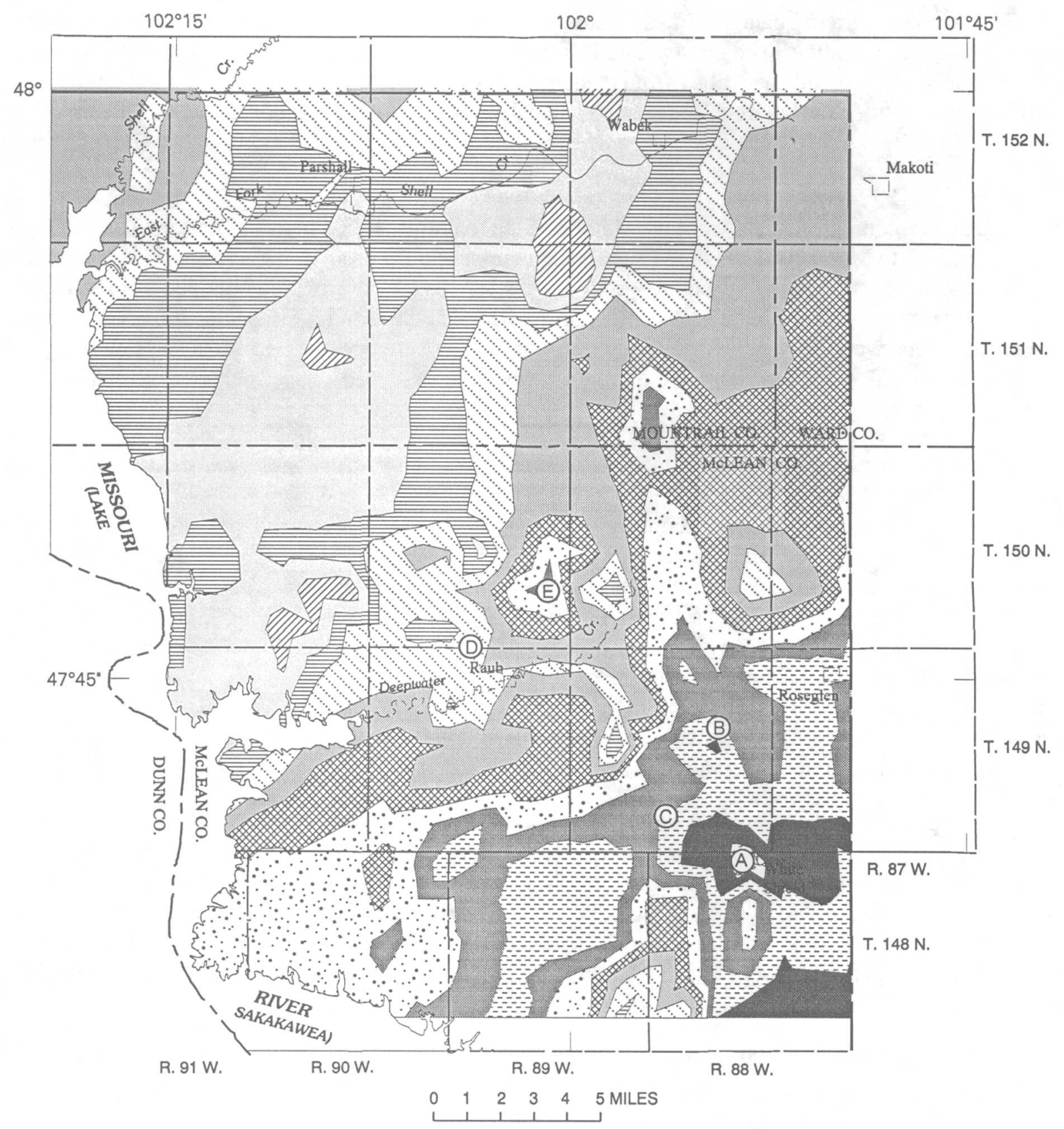

EXPLANATION

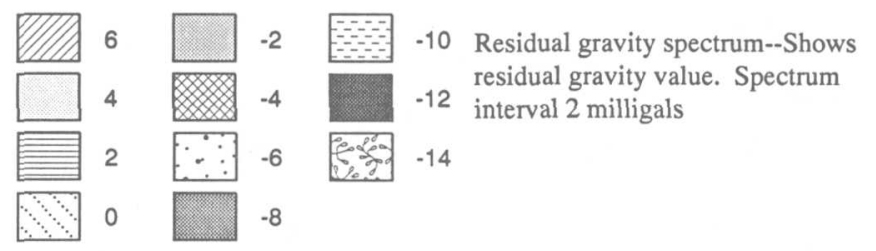

Fort Berthod Indian Reservation boundary
(A) Gravity low coincident with buried valley

(B) North-south trending paleodrainage

(C) Ground-water divide

(D) Gravity high

(E) Gravity low north of main buried valley

Figure 22. Residual gravity in the eastern part of the Fort Berthold Indian Reservation. 

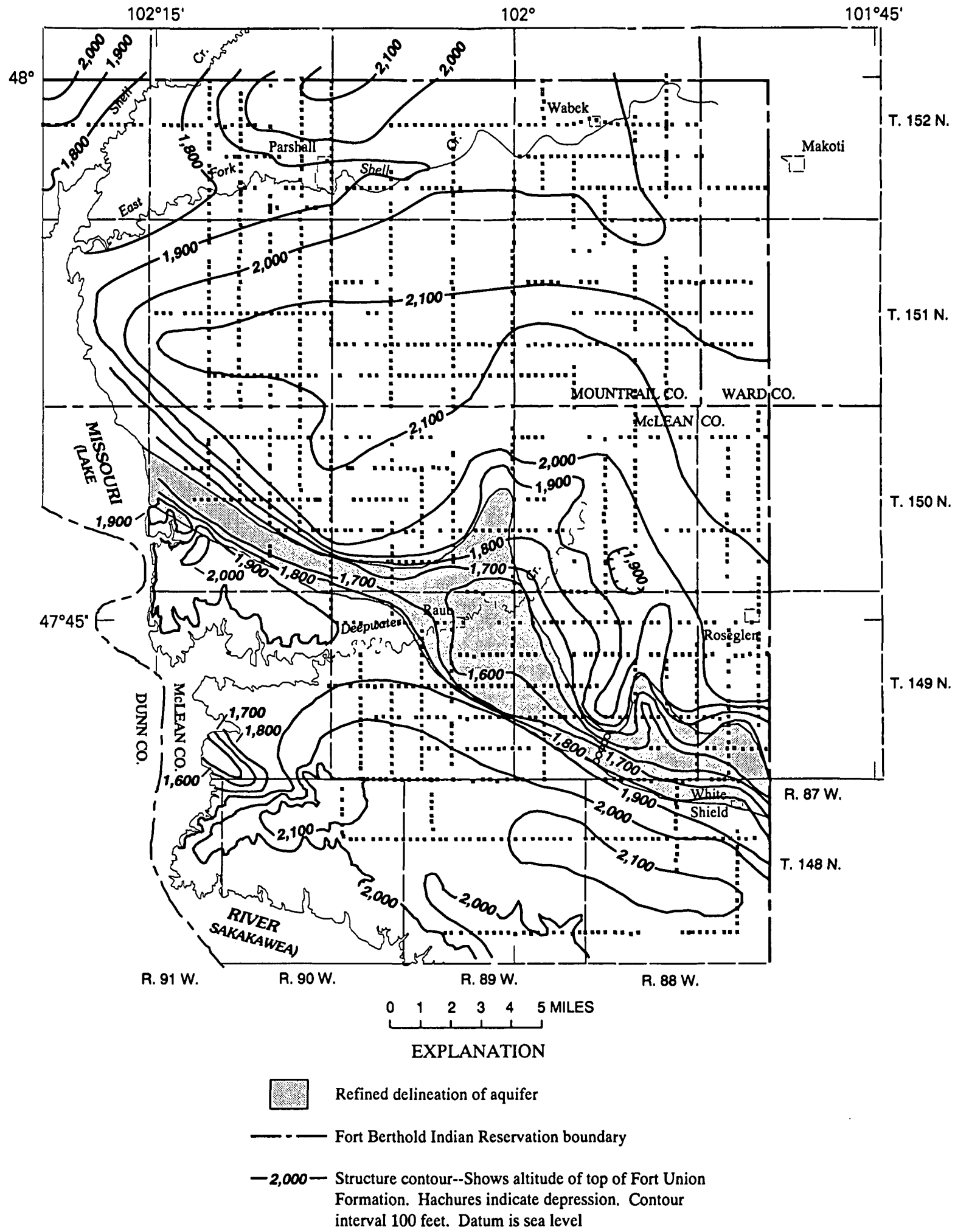

$\infty 000000$ Ground-water divide

- Gravity reading

Figure 23. Altitude of the top of the Fort Union Formation near the White Shield aquifer. 


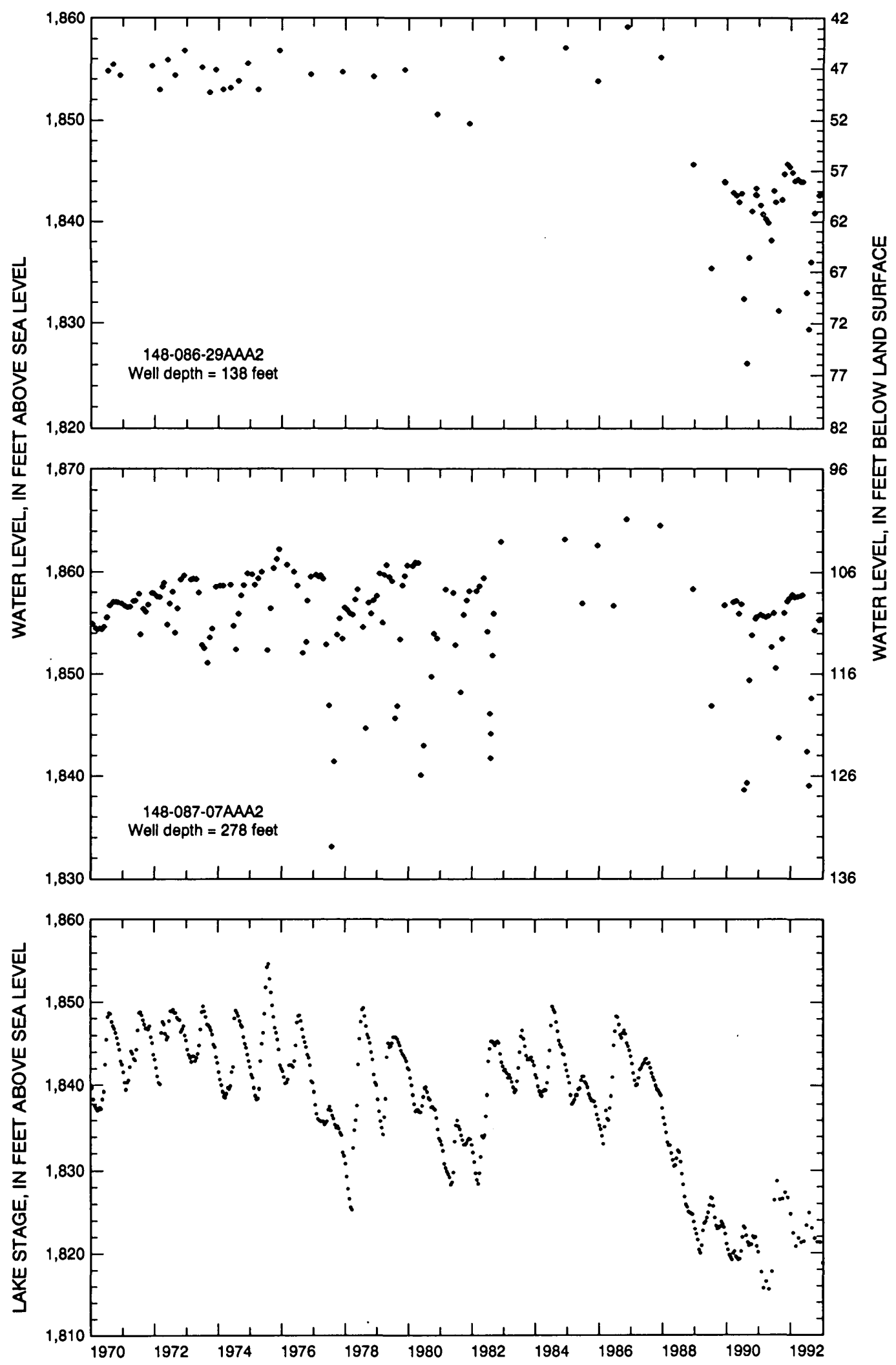

Figure 24. Water levels in wells completed in the eastern part of the White Shield aquifer and lake stage of Lake Sakakawea, 1970-92. 


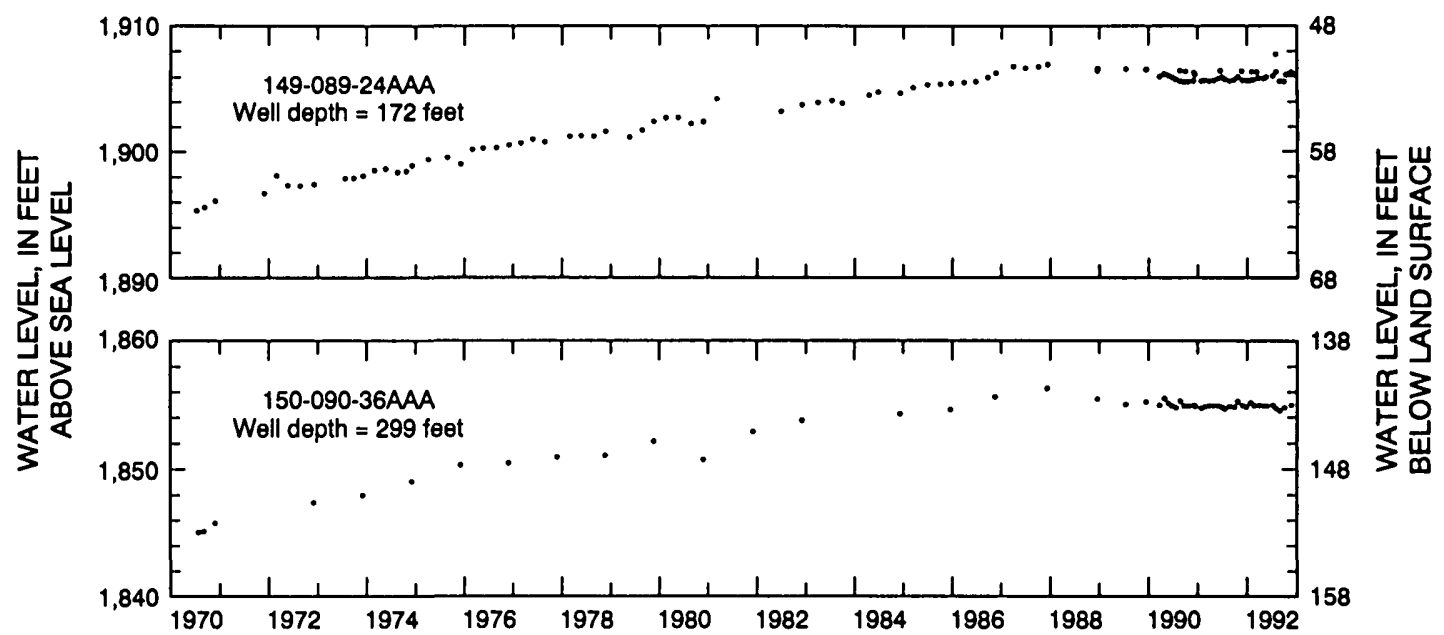

Figure 25. Water levels in wells completed in the western part of the White Shield aquifer, 1970-92.

The sodium hazard for water from both parts of the White Shield aquifer, as indicated by the sodium adsorption ratio (table 8), generally is low (fig. 10). The salinity hazard for water from both parts of the aquifer, as indicated by the specific-conductance value, generally is high. The combination of these two hazards indicates that water from the White Shield aquifer is suitable for irrigation on soils that have high permeability.

\section{New Town}

The New Town aquifer lies within a buried valley that is as much as 307 feet deep and between 1.75 and 4.7 miles wide. The aquifer, which underlies New Town (fig. 16), is confined and has an areal extent of about 18 square miles within the Reservation. The aquifer is the major source of water for New Town.

Lenticular deposits of sand and gravel that comprise the aquifer generally occur at the base of the buried valley and are overlain by a confining layer of between 50 and 250 feet of till and clay (figs. 28 and 29). Thickness of the New Town aquifer ranges from less than 10 to 95 feet and averages about 50 feet.

An aquifer test conducted at a city-owned well at New Town (Armstrong, 1971) indicated transmissivity ranged from about 18,800 to 34,800 feet squared per day. This variability was attributed to local variations in the thickness of sands and gravels in the aquifer. The storage coefficient ranged from 0.0001 to 0.0007 . Based on an areal extent of 18 square miles, an average cumulative thickness of 50 feet, and an assumed porosity of 30 percent, the volume of water stored in the New Town aquifer is about 170,000 acre-feet.

Data obtained during 1967-92 for well 152-092-19AAB indicate a close correspondence between ground-water levels in the well and lake stage of Lake Sakakawea (fig. 30). Armstrong (1971) suggested that the similarity between the water level and the lake stage indicates a direct hydraulic connection between the New Town aquifer and the lake.

Data are insufficient to define the recharge and discharge conditions in the New Town aquifer. However, water-quality similarities and the correspondence between ground-water levels and lake stage indicate interchange between the aquifer and Lake Sakakawea. 
Table 8. Statistical summary of selected water-quality data for the White Shield aquifer, 1966-92

$\left[\mu \mathrm{S} / \mathrm{cm}\right.$, microsiemens per centimeter; ${ }^{\circ} \mathrm{C}$, degrees Celsius; --, not available; $\mathrm{mg} / \mathrm{L}$, milligrams per liter; <, less than; $\mu \mathrm{g} / \mathrm{L}$, micrograms per liter]

\begin{tabular}{|c|c|c|c|c|c|}
\hline $\begin{array}{l}\text { Physical property or } \\
\text { chemical constituent }\end{array}$ & $\begin{array}{l}\text { Number of } \\
\text { samples }\end{array}$ & Maximum & Minimum & Mean & Median \\
\hline \multicolumn{6}{|c|}{ Eastern part of aquifer } \\
\hline Specific conductance, field $\left(\mu \mathrm{S} / \mathrm{cm}\right.$ at $\left.25^{\circ} \mathrm{C}\right)$ & 9 & 2,070 & 1,360 & 1,630 & 1,470 \\
\hline $\mathrm{pH}$, field (standard units) & 9 & 9.4 & 7.1 & -- & 8.0 \\
\hline Hardness $\left(\mathrm{mg} / \mathrm{L}\right.$ as $\left.\mathrm{CaCO}_{3}\right)$ & 9 & 670 & 190 & 360 & 320 \\
\hline Calcium, dissolved (mg/L) & 9 & 180 & 20 & 78 & 76 \\
\hline Magnesium, dissolved (mg/L) & 9 & 54 & 28 & 41 & 38 \\
\hline Sodium, dissolved $(\mathrm{mg} / \mathrm{L})$ & 9 & 410 & 87 & 250 & 230 \\
\hline Sodium adsorption ratio & 9 & 12 & 1.0 & 6.0 & 6.0 \\
\hline Potassium, dissolved (mg/L) & 9 & 14 & 5.6 & 8.1 & 7.2 \\
\hline Bicarbonate, field $\left(\mathrm{mg} / \mathrm{L}\right.$ as $\left.\mathrm{CaCO}_{3}\right)$ & 6 & 840 & 570 & 670 & 620 \\
\hline Alkalinity, total $\left(\mathrm{mg} / \mathrm{L}\right.$ as $\left.\mathrm{CaCO}_{3}\right)$ & 3 & 711 & 477 & -- & 692 \\
\hline Sulfate, dissolved (mg/L) & 9 & 630 & 130 & 350 & 330 \\
\hline Chloride, dissolved (mg/L) & 8 & 11 & 3.0 & 5.9 & 5.7 \\
\hline Fluoride, dissolved $(\mathrm{mg} / \mathrm{L})$ & 9 & 0.7 & $<0.1$ & 0.4 & 0.4 \\
\hline Silica, dissolved $(\mathrm{mg} / \mathrm{L})$ & 9 & 31 & 23 & 26 & 26 \\
\hline Dissolved solids, sum of constituents (mg/L) & 9 & 1,480 & 853 & 1,080 & 898 \\
\hline Boron, dissolved $(\mu \mathrm{g} / \mathrm{L})$ & 5 & 630 & 350 & 490 & 490 \\
\hline Iron, dissolved $(\mu \mathrm{g} / \mathrm{L})$ & 6 & 10,000 & $<10$ & 3,030 & 1,380 \\
\hline Manganese, dissolved $(\mu \mathrm{g} / \mathrm{L})$ & 7 & 180 & 10 & 54 & 30 \\
\hline \multicolumn{6}{|c|}{ Western part of aquifer } \\
\hline Specific conductance, field $\left(\mu \mathrm{S} / \mathrm{cm}\right.$ at $\left.25^{\circ} \mathrm{C}\right)$ & 11 & 3,240 & 843 & 2,020 & 2,100 \\
\hline $\mathrm{pH}$, field (standard units) & 11 & 8.4 & 7.0 & -- & 7.9 \\
\hline Hardness $\left(\mathrm{mg} / \mathrm{L}\right.$ as $\left.\mathrm{CaCO}_{3}\right)$ & 11 & 640 & 120 & 410 & 420 \\
\hline Calcium, dissolved (mg/L) & 11 & 160 & 26 & 90 & 98 \\
\hline Magnesium, dissolved (mg/L) & 11 & 75 & 12 & 45 & 42 \\
\hline Sodium, dissolved (mg/L) & 11 & 690 & 29 & 330 & 300 \\
\hline Sodium adsorption ratio & 11 & 24 & 0.6 & 8.6 & 5.0 \\
\hline Potassium, dissolved $(\mathrm{mg} / \mathrm{L})$ & 11 & 10 & 3.9 & 7.3 & 7.2 \\
\hline Bicarbonate, field $\left(\mathrm{mg} / \mathrm{L}\right.$ as $\left.\mathrm{CaCO}_{3}\right)$ & 8 & 930 & 410 & 747 & 781 \\
\hline Alkalinity, lab, total $\left(\mathrm{mg} / \mathrm{L}\right.$ as $\left.\mathrm{CaCO}_{3}\right)$ & 8 & 787 & 376 & 566 & 575 \\
\hline Sulfate, dissolved (mg/L) & 11 & 1,000 & 77 & 550 & 580 \\
\hline Chloride, dissolved (mg/L) & 11 & 35 & 4.0 & 11 & 6.4 \\
\hline Fluoride, dissolved (mg/L) & 11 & 1.6 & $<0.1$ & 0.6 & 0.4 \\
\hline Silica, dissolved (mg/L) & 11 & 32 & 23 & 28 & 27 \\
\hline Dissolved solids, sum of constituents (mg/L) & 11 & 2,340 & 513 & 1,430 & 1,420 \\
\hline Boron, dissolved $(\mu \mathrm{g} / \mathrm{L})$ & 7 & 640 & 100 & 490 & 560 \\
\hline Iron, dissolved $(\mu \mathrm{g} / \mathrm{L})$ & 7 & 3,800 & 40 & 1,250 & 810 \\
\hline Manganese, dissolved $(\mu \mathrm{g} / \mathrm{L})$ & 5 & 580 & 18 & 160 & 77 \\
\hline Strontium, dissolved $(\mu \mathrm{g} / \mathrm{L})$ & 5 & 2,000 & 600 & 1,200 & 1,100 \\
\hline
\end{tabular}

A statistical summary of selected water-quality data for the New Town aquifer is given in table 9 . The data pertain to samples collected from 10 wells in the aquifer during 1966-87. If more than one sample was collected from a well, only the most recent sample was used in the summary. Generally, water in the 
aquifer is a calcium sodium bicarbonate sulfate type (fig. 31). Dissolved-solids concentrations ranged from 1,000 to 2,580 milligrams per liter and had a median of 1,180 milligrams per liter. Dissolved-solids concentrations in all samples collected from the aquifer exceeded the secondary maximum contaminant level of 500 milligrams per liter (table 2). The minimum sulfate concentration, the median iron concentration, and the only determined manganese concentration also exceeded the secondary maximum contaminant levels.

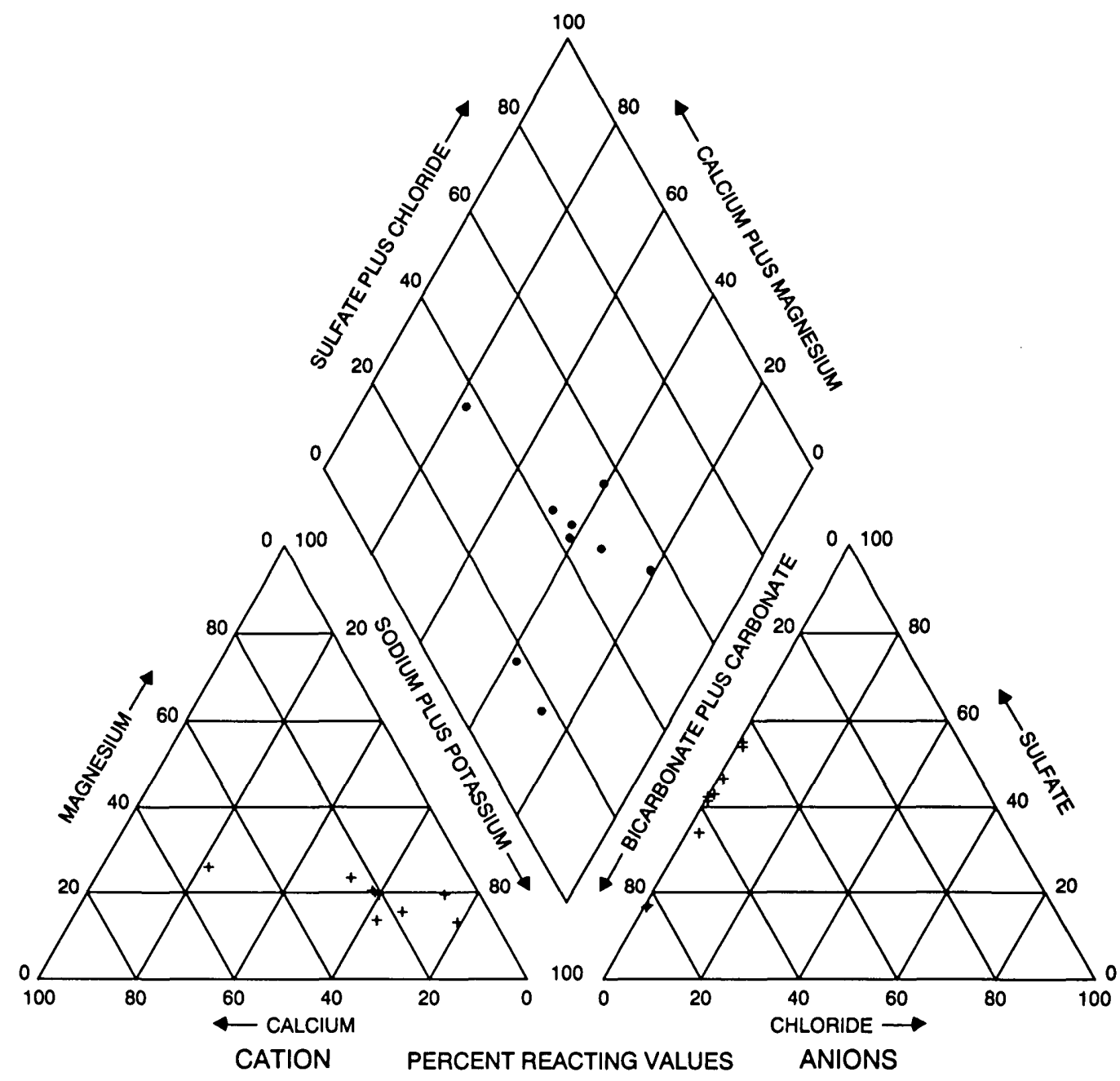

Figure 26. Major-ion composition of water in the eastern part of the White Shield aquifer.

The sodium hazard for water from the New Town aquifer, as indicated by the sodium adsorption ratio (table 9), generally is low (fig. 10). The salinity hazard, as indicated by the specific-conductance value, generally is high. The combination of these two hazards indicates that water from the New Town aquifer is suitable for irrigation on soils that have high permeability.

\section{Sanish}

The Sanish aquifer lies within a buried valley about 6 miles south of New Town (fig. 16) and has an areal extent of about 8.5 square miles. The confined aquifer is composed of sand, clayey sand, and thin 


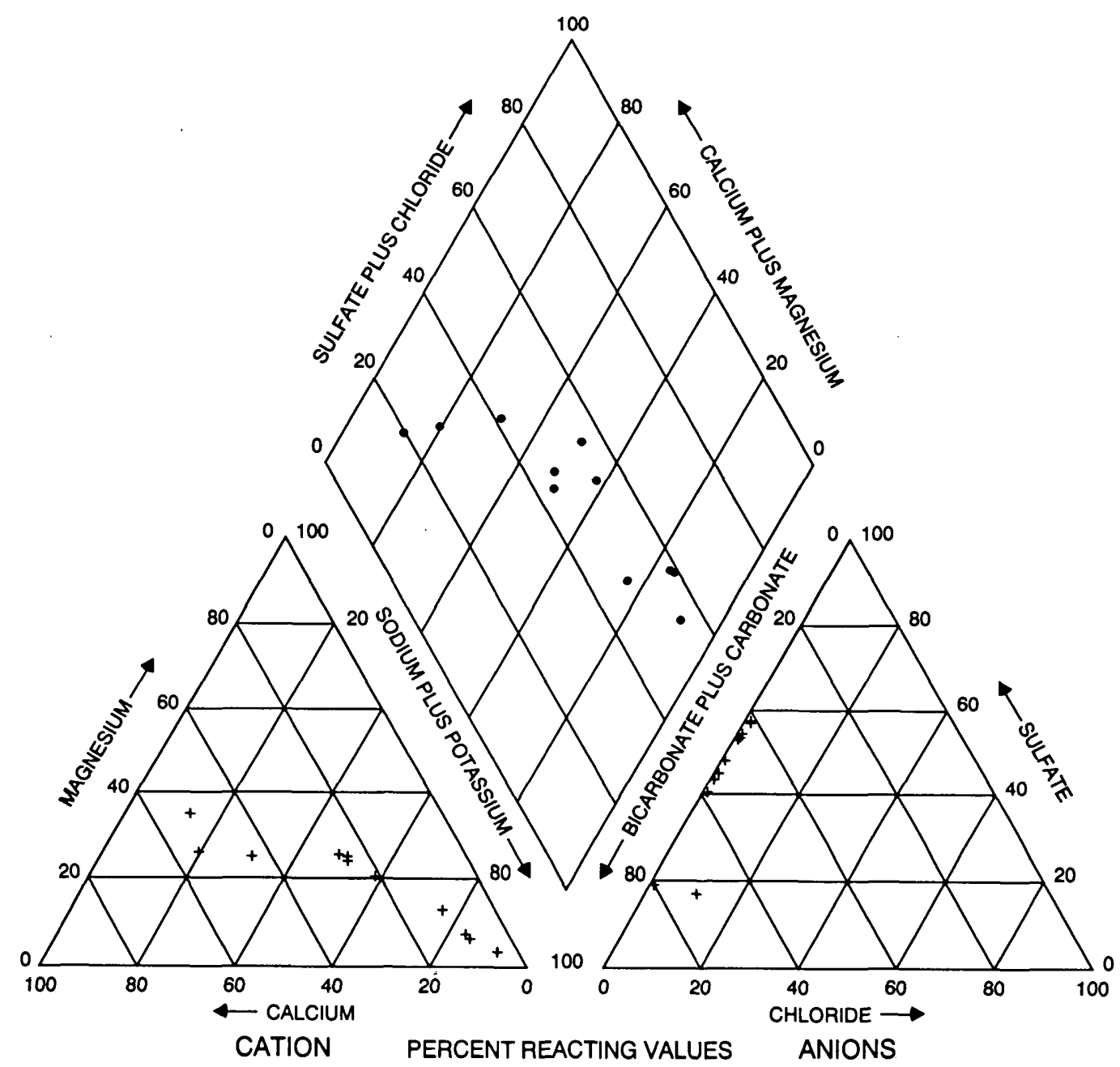

Figure 27. Major-ion composition of water in the Western part of the White Shield aquifer.

gravels at the base of the buried valley (fig. 32). Sand layers within the aquifer range from 25 to 270 feet in thickness, and gravel layers range from 3 to 30 feet in thickness. The aquifer matrix is poorly cemented, generally noncohesive, and highly permeable.

To define the geometry of the Sanish aquifer, high-accuracy gravity data (Wald and Cates, 1995) were used to select four test-drilling locations. All four of the test holes penetrated the Sanish aquifer in places where the location of the aquifer was undefined before drilling.

Long-term water-level data for the Sanish aquifer are unavailable. The permeable nature of the Sanish aquifer and the large gravel outcrop that occurs near T. 151 N., R. 93 W., where the northwestern end of the buried valley intersects Lake Sakakawea, allows the assumption that, similar to the New Town aquifer, the Sanish aquifer and Lake Sakakawea may be in hydraulic connection. Based on an areal extent of 8.5 square miles, an average cumulative thickness of $125 \mathrm{feet}$, and an assumed porosity of 35 percent, the volume of water stored in the Sanish aquifer is about 240,000 acre-feet.

Water levels in wells completed in the Sanish aquifer indicate ground water generally flows to the west, and the hydraulic gradient in the aquifer is about 1 foot per mile. Data are insufficient, however, to define the recharge-discharge relations between the Sanish aquifer, the Tongue River and Sentinel Butte aquifers, and Lake Sakakawea. 


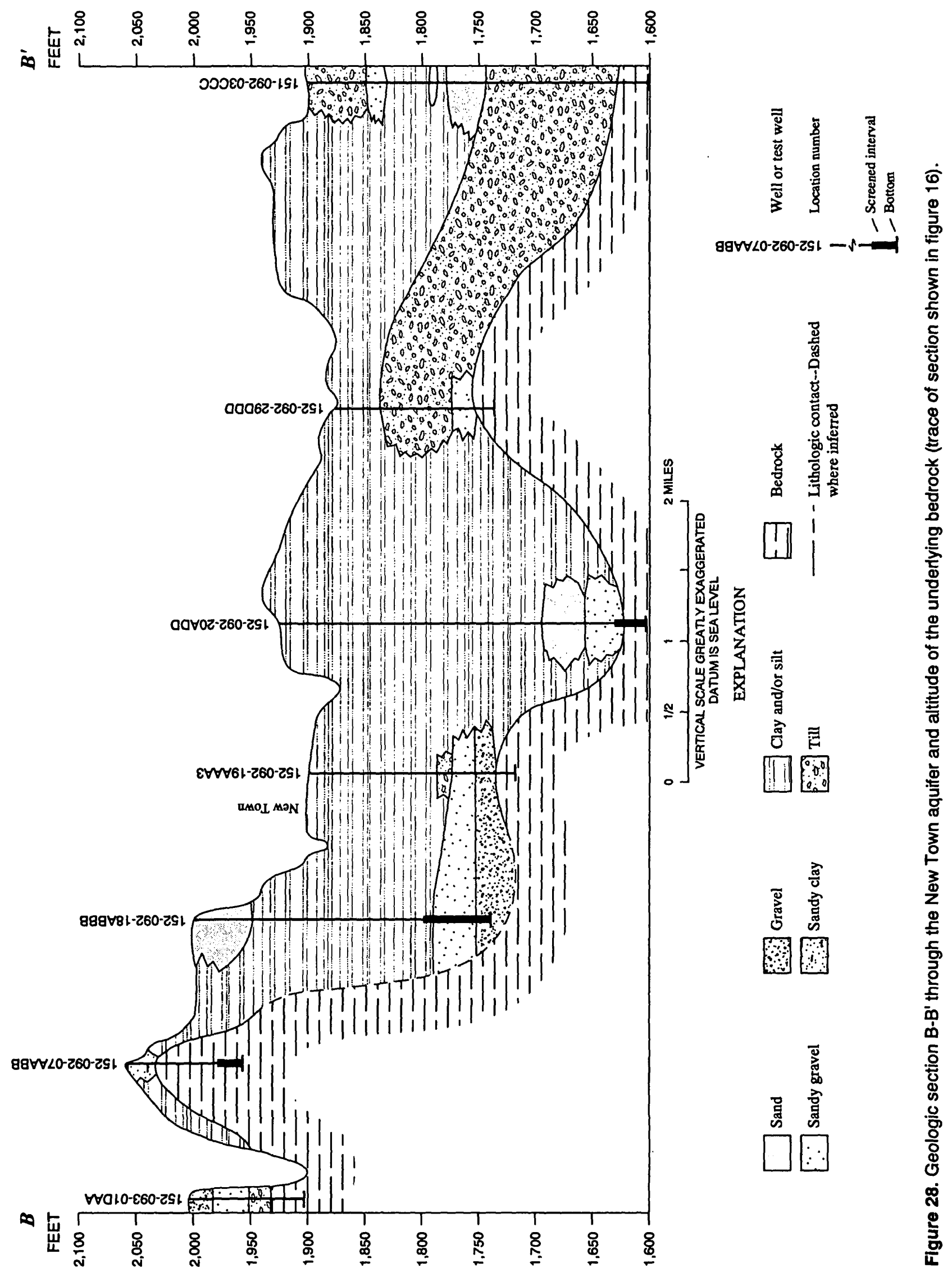




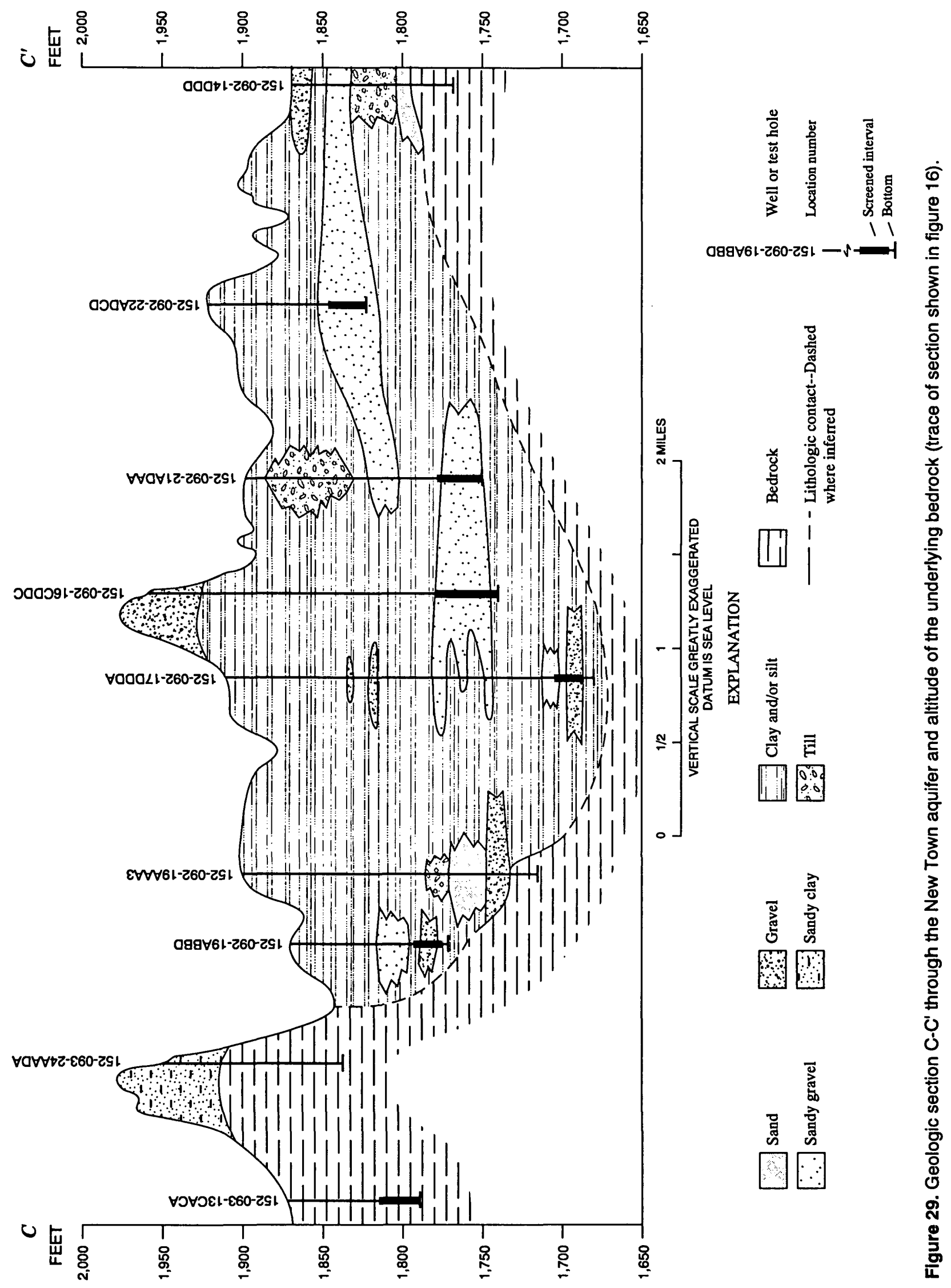




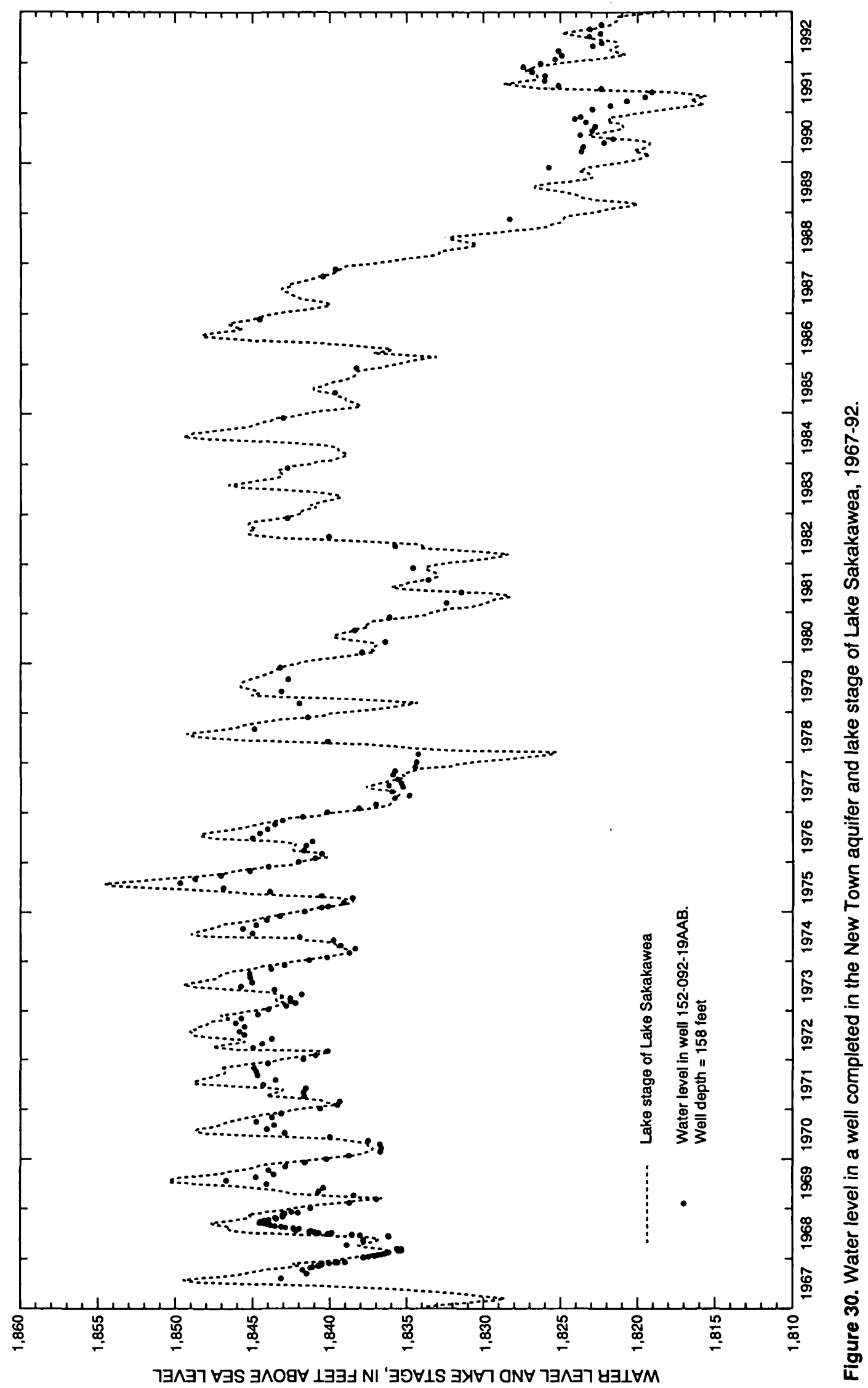


Table 9. Statistical summary of selected water-quality data for the New Town aquifer, 1966-87

$\left[\mu \mathrm{S} / \mathrm{cm}\right.$, microsiemens per centimeter; ${ }^{\circ} \mathrm{C}$, degrees Celsius; --, not available; $\mathrm{mg} / \mathrm{L}$, milligrams per liter; $\mu \mathrm{g} / \mathrm{L}$, micrograms per liter]

\begin{tabular}{|c|c|c|c|c|c|}
\hline $\begin{array}{l}\text { Physical property or } \\
\text { chemical constituent }\end{array}$ & $\begin{array}{l}\text { Number of } \\
\text { samples }\end{array}$ & Maximum & Minimum & Mean & Median \\
\hline Specific conductance, field $\left(\mu \mathrm{S} / \mathrm{cm}\right.$ at $\left.25^{\circ} \mathrm{C}\right)$ & 10 & 3,700 & 1,410 & 1,940 & 1,680 \\
\hline $\mathrm{pH}$, field (standard units) & 10 & 8.1 & 7.1 & -- & 7.8 \\
\hline Hardness $\left(\mathrm{mg} / \mathrm{L}\right.$ as $\left.\mathrm{CaCO}_{3}\right)$ & 10 & 1,000 & 100 & 509 & 465 \\
\hline Calcium, dissolved $(\mathrm{mg} / \mathrm{L})$ & 10 & 270 & 28 & 129 & 125 \\
\hline Magnesium, dissolved (mg/L) & 10 & 85 & 8.3 & 46 & 40 \\
\hline Sodium, dissolved $(\mathrm{mg} / \mathrm{L})$ & 10 & 930 & 52 & 283 & 210 \\
\hline Sodium adsorption ratio & 10 & 40 & 0.7 & 8.0 & 4.0 \\
\hline Potassium, dissolved (mg/L) & 10 & 15 & 3.8 & 7.2 & 6.2 \\
\hline Bicarbonate, field, total $\left(\mathrm{mg} / \mathrm{L}\right.$ as $\left.\mathrm{CaCO}_{3}\right)$ & 9 & 1,580 & 400 & 693 & 550 \\
\hline Sulfate, dissolved $(\mathrm{mg} / \mathrm{L})$ & 10 & 1,000 & 340 & 560 & 465 \\
\hline Chloride, dissolved (mg/L) & 10 & 17 & 0.6 & 5.1 & 3.4 \\
\hline Fluoride, dissolved $(\mathrm{mg} / \mathrm{L})$ & 7 & 0.2 & 0.1 & 0.1 & 0.1 \\
\hline Silica, dissolved $(\mathrm{mg} / \mathrm{L})$ & 10 & 34 & 22 & 29 & 29 \\
\hline Dissolved solids, sum of constituents (mg/L) & 10 & 2,580 & 1,000 & 1,390 & 1,180 \\
\hline Boron, dissolved $(\mu \mathrm{g} / \mathrm{L})$ & 7 & 620 & 160 & 280 & 260 \\
\hline Iron, dissolved $(\mu \mathrm{g} / \mathrm{L})$ & 7 & 4,900 & 80 & 2,340 & 2,200 \\
\hline Manganese, dissolved $(\mu \mathrm{g} / \mathrm{L})$ & 1 & 320 & -. & - & - \\
\hline Strontium, dissolved $(\mu \mathrm{g} / \mathrm{L})$ & 1 & 1,300 & -- & -- & -- \\
\hline
\end{tabular}

A statistical summary of selected water-quality data for the Sanish aquifer is given in table 10. The data pertain to samples collected from six wells in the aquifer during 1966-92. If more than one sample was collected from a well, only the most recent sample was used in the summary. Generally, water in the aquifer is a mixed calcium magnesium bicarbonate sulfate type (fig. 33). Dissolved-solids concentrations ranged from 459 to 2,690 milligrams per liter and had a median of 1,140 milligrams per liter. Dissolvedsolids concentrations in at least half of the samples collected from the aquifer exceeded the secondary maximum contaminant level of 500 milligrams per liter (table 2). The median sulfate and iron concentrations and the minimum manganese concentration also exceeded the secondary maximum contaminant levels.

The sodium hazard for water from the Sanish aquifer, as indicated by the sodium adsorption ratio (table 10), generally is low (fig. 10). The salinity hazard, as indicated by the specific-conductance value, generally is high. The combination of these two hazards indicates that water from the Sanish aquifer is suitable for irrigation on soils that have high permeability.

\section{SPRINGS}

Most of the springs on the Reservation are located south of Lake Sakakawea in the Dunn County, McKenzie County, and Mercer County parts of the Reservation and flow from the Sentinel Butte aquifer. The springs generally discharge from lignite beds but, in some places, discharge from sandstone beds that are underlain by impermeable clay or silt. The springs generally are located on the lower parts of the various drainages on the Reservation or at the base of the valley walls. 


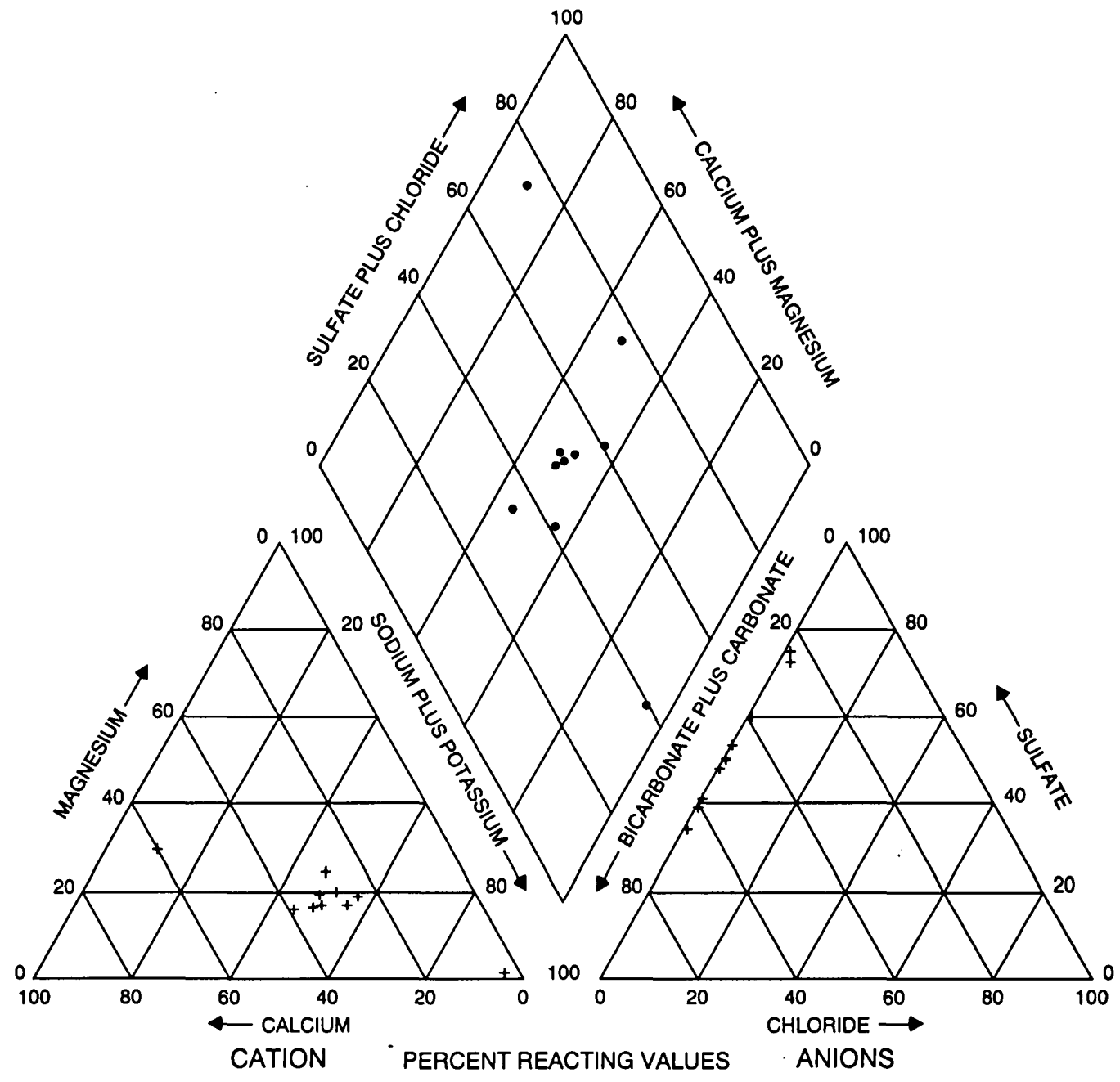

Figure 31. Major-ion composition of water in the New Town aquifer.

Most of the springs are seasonal seeps and have flows of less than 1 gallon per minute. Some springs, however, have continuous flows that generally range from 3 to 10 gallons per minute. The largest spring on the Reservation flows at about 180 gallons per minute and occurs as an extensive seep area of several hundred square feet in sec. 6, T. 151 N., R. 94 W.

A statistical summary of selected water-quality data for springs on the Reservation is given in table 11. The data pertain to samples collected from 31 springs during 1950-92. If more than one sample was collected from a spring, only the most recent sample was used in the summary. Water in the springs varies from a sodium bicarbonate sulfate type to a mixed calcium magnesium sodium bicarbonate sulfate type (fig. 34). Dissolved-solids concentrations ranged from 275 to 6,410 milligrams per liter and had a median of 768 milligrams per liter. Dissolved-solids concentrations in at least half of the samples collected from springs exceeded the secondary maximum contaminant level of 500 milligrams per liter (table 2). The median sulfate and manganese concentrations equaled or exceeded the secondary maximum contaminant levels, and the maximum iron concentration exceeded the secondary maximum contaminant levels. 


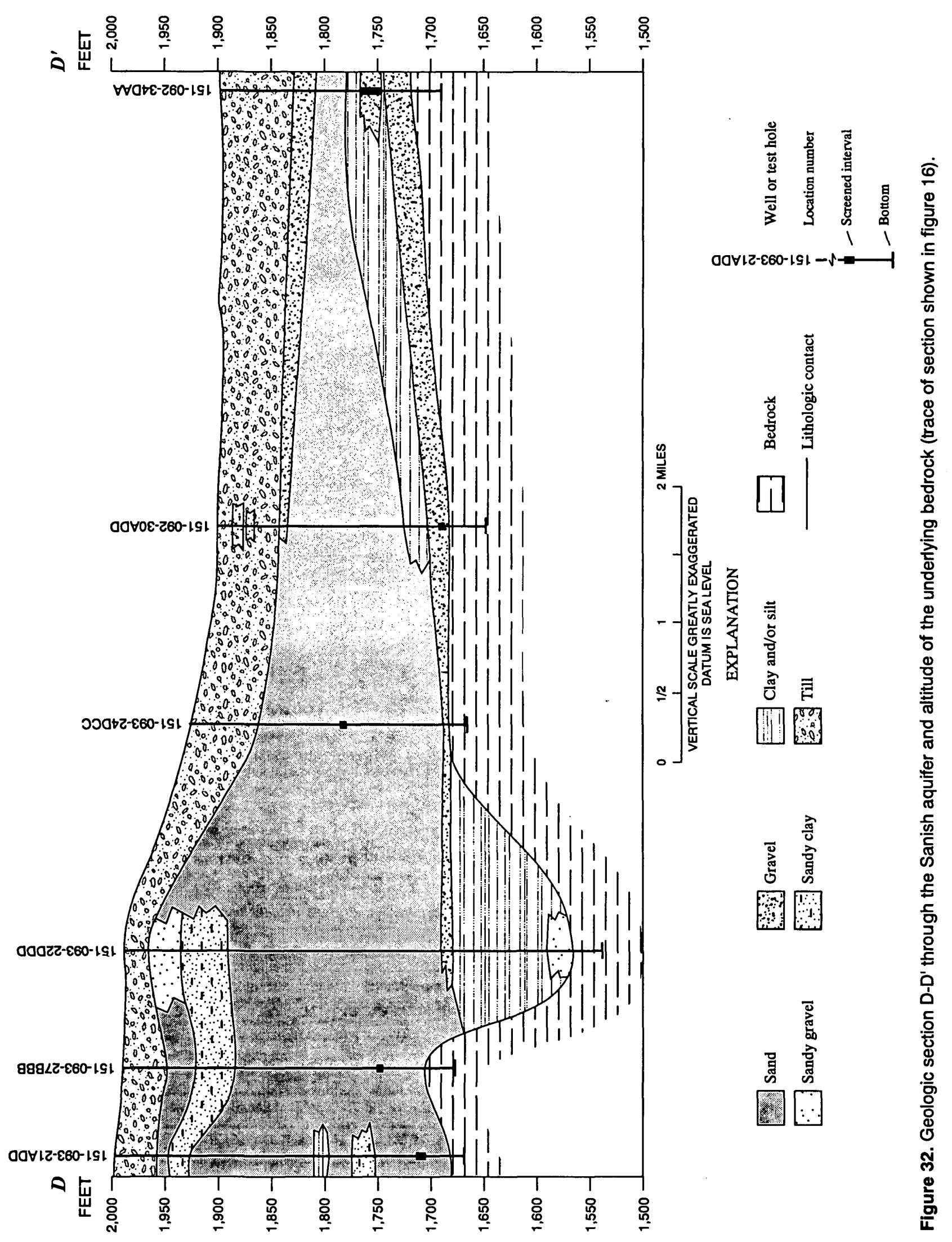


Table 10. Statistical summary of selected water-quality data for the Sanish aquifer, 1966-92

$\left[\mu \mathrm{S} / \mathrm{cm}\right.$, microsiemens per centimeter; ${ }^{\circ} \mathrm{C}$, degrees Celsius;,-- not available; $\mathrm{mg} / \mathrm{L}$, milligrams per liter; $\mu \mathrm{g} / \mathrm{L}$, micrograms per liter]

\begin{tabular}{|c|c|c|c|c|c|}
\hline $\begin{array}{l}\text { Physical property or } \\
\text { chemical constituent }\end{array}$ & $\begin{array}{l}\text { Number of } \\
\text { samples }\end{array}$ & Maximum & Minimum & Mean & Median \\
\hline Specific conductance, field $\left(\mu \mathrm{S} / \mathrm{cm}\right.$ at $\left.25^{\circ} \mathrm{C}\right)$ & 6 & 3,640 & 727 & 1,840 & 1,640 \\
\hline $\mathrm{pH}$, field (standard units) & 6 & 8.1 & 7.2 & -- & 7.4 \\
\hline Hardness $\left(\mathrm{mg} / \mathrm{L}\right.$ as $\left.\mathrm{CaCO}_{3}\right)$ & 6 & 900 & 280 & 500 & 460 \\
\hline Calcium, dissolved $(\mathrm{mg} / \mathrm{L})$ & 6 & 210 & 88 & 120 & 110 \\
\hline Magnesium, dissolved (mg/L) & 6 & 90 & 15 & 49 & 48 \\
\hline Sodium, dissolved (mg/L) & 6 & 720 & 55 & 280 & 240 \\
\hline Sodium adsorption ratio & 6 & 13 & 1.0 & 5.0 & 4.0 \\
\hline Potassium, dissolved (mg/L) & 6 & 12 & -7.3 & 9.5 & 9.0 \\
\hline Bicarbonate, field, total $\left(\mathrm{mg} / \mathrm{L}\right.$ as $\left.\mathrm{CaCO}_{3}\right)$ & 6 & 1,080 & 450 & 750 & 760 \\
\hline Alkalinity, lab, total $\left(\mathrm{mg} / \mathrm{L}\right.$ as $\left.\mathrm{CaCO}_{3}\right)$ & 6 & 900 & 375 & 626 & 634 \\
\hline Sulfate, dissolved $(\mathrm{mg} / \mathrm{L})$ & 6 & 1,200 & 37 & 470 & 355 \\
\hline Chloride, dissolved (mg/L) & 6 & 13 & 0.7 & 5.3 & 4.2 \\
\hline Fluoride, dissolved $(\mathrm{mg} / \mathrm{L})$ & 6 & 1.2 & 0.2 & 0.6 & 0.5 \\
\hline Silica, dissolved $(\mathrm{mg} / \mathrm{L})$ & 6 & 40 & 22 & 33 & 36 \\
\hline Dissolved solids, sum of constituents $(\mathrm{mg} / \mathrm{L}$ ) & 6 & 2,690 & 459 & 1,350 & 1,140 \\
\hline Boron, dissolved $(\mu \mathrm{g} / \mathrm{L})$ & 2 & 780 & 120 & -- & -- \\
\hline Iron, dissolved $(\mu \mathrm{g} / \mathrm{L})$ & 6 & 8,600 & 9 & 2,800 & 960 \\
\hline Manganese, dissolved $(\mu \mathrm{g} / \mathrm{L})$ & 4 & 880 & 91 & -. & -- \\
\hline
\end{tabular}

\section{SURFACE WATER}

Surface-water resources of the Fort Berthold Indian Reservation consist of many ephemeral streams and Lake Sakakawea. Major streams on the Reservation are Bear Den Creek, Shell Creek, East Fork Shell Creek, Deepwater Creek, Moccasin Creek, and Squaw Creek, all of which are tributaries to Lake Sakakawea (fig. 35). Parts of the drainage basins of Bear Den Creek, Shell Creek, East Fork Shell Creek, and Deepwater Creek are located outside of the Reservation. The drainage basins of Moccasin Creek and Squaw Creek are located entirely within the Reservation. All of the basins except that of Moccasin Creek have noncontributing drainage areas.

Shell Creek, East Fork Shell Creek, and Deepwater Creek flow through the northern and eastern parts of the Reservation and are incised into the glacial sediments. These streams have larger drainage basins, smaller stream slopes, and lower mean basin elevations than Bear Den Creek, Moccasin Creek, and Squaw Creek (table 12). Bear Den Creek, Moccasin Creek, and Squaw Creek flow through the western and southwestern parts of the Reservation and are incised into bedrock units.

Historic streamflow data were obtained for one active continuous-record gaging station (Bear Den Creek near Mandaree, N. Dak., 06332515) and for one discontinued continuous-record gaging station (Shell Creek near Parshall, N. Dak., 06332520) (fig. 35). Monthly streamflow data were collected at five miscellaneous discharge-measurement sites (Bear Den Creek above mouth near Mandaree, N. Dak., 06332517; East Fork Shell Creek near mouth below Parshall, N. Dak., 06332524; Deepwater Creek at mouth near Raub, N. Dak., 06332770; Moccasin Creek at mouth near Mandaree, N. Dak., 06337470; and Squaw Creek above mouth near Mandaree, N. Dak. 06337480) (fig. 35) that were established in April 
1990 on streams within the Reservation. The Bear Den Creek above mouth near Mandaree, N. Dak., miscellaneous site was discontinued in September 1990 and was replaced by the Bear Den Creek near Mandaree, N. Dak., gaging station, which is located a few miles upstream from the miscellaneous site. The East Fork Shell Creek and Deepwater Creek miscellaneous sites were converted to continuous-record gaging stations in June 1991, and, thereafter, streamflow was measured every 6 weeks instead of monthly. At the time of conversion, the East Fork Shell Creek site was moved a couple of miles upstream. Data for selected streams and for Lake Sakakawea are published in annual data reports for 1965-92 (U.S.

Geological Survey, 1966-93).

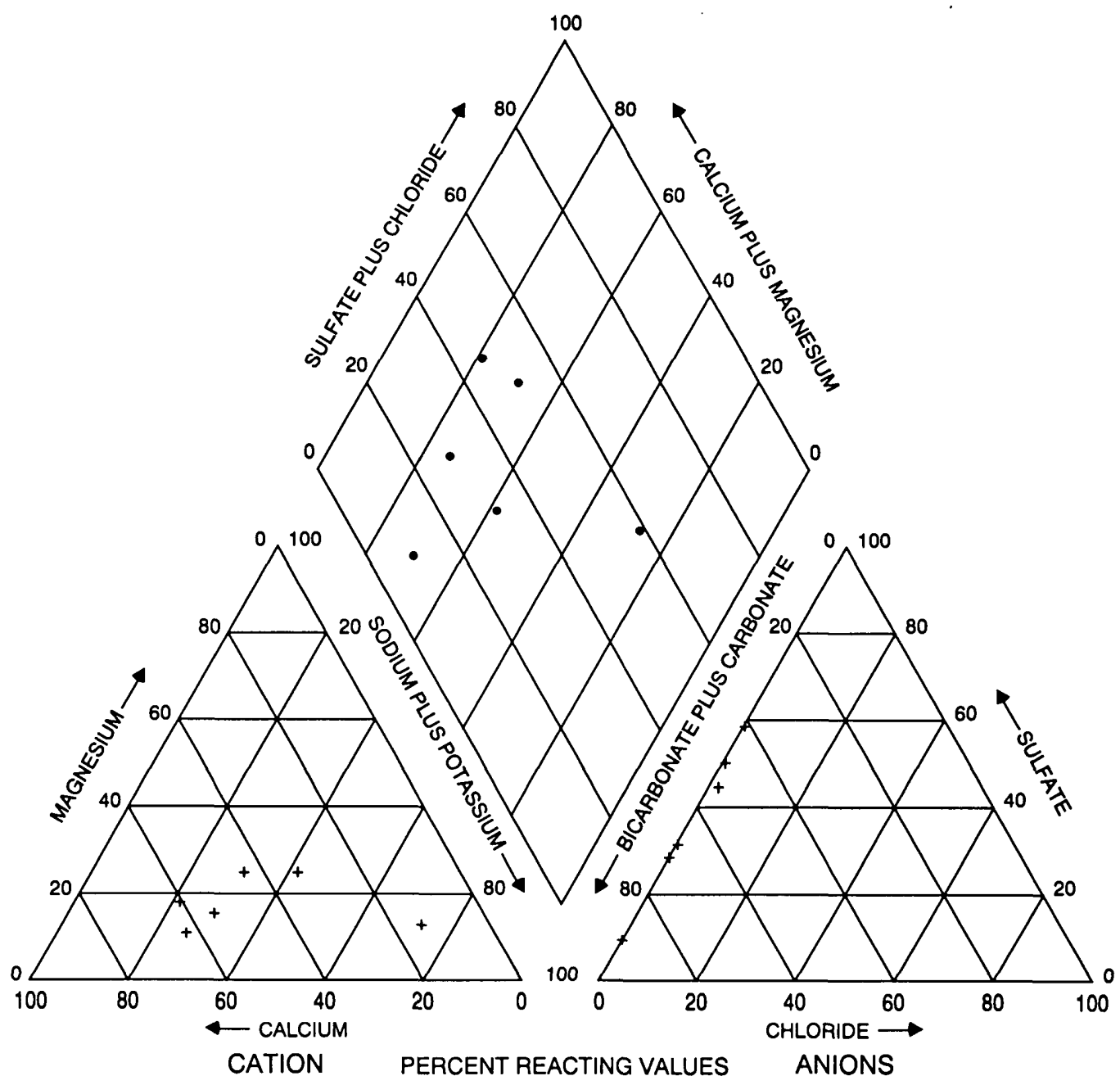

Figure 33. Major-ion composition of water in the Sanish aquifer.

Water samples were collected from five streams during April 1990 through September 1992 and analyzed for selected physical properties and chemical constituents (major anions and cations, nutrients, and some pesticides and herbicides). Specific conductance, $\mathrm{pH}$, and dissolved oxygen concentrations were measured at the time of each streamflow measurement. Data obtained from the analyses are published in annual data reports for 1990-92 (U.S. Geological Survey, 1991-93). Because of a sustained drought during the study, streamflow was low or nonexistent for all of the streams during much of each year, limiting the number of water-quality samples. 
Table 11. Statistical summary of selected water-quality data for springs on the Fort Berthold Indian Reservation, $1950-92$

$\left[\mu \mathrm{S} / \mathrm{cm}\right.$, microsiemens per centimeter; ${ }^{\circ} \mathrm{C}$, degrees Celsius; --, not available; $\mathrm{mg} / \mathrm{L}$, milligrams per liter; <, less than; $\mu \mathrm{g} / \mathrm{L}$, micrograms per liter]

\begin{tabular}{|c|c|c|c|c|c|}
\hline $\begin{array}{l}\text { Physical property or } \\
\text { chemical constituent }\end{array}$ & $\begin{array}{l}\text { Number of } \\
\text { samples }\end{array}$ & Maximum & Minimum & Mean & Median \\
\hline Specific conductance, field $\left(\mu \mathrm{S} / \mathrm{cm}\right.$ at $\left.25^{\circ} \mathrm{C}\right)$ & 31 & 6,290 & 447 & 1,440 & 1,120 \\
\hline $\mathrm{pH}$, field (standard units) & 31 & 7.9 & 4.5 & -- & 7.1 \\
\hline Hardness $\left(\mathrm{mg} / \mathrm{L}\right.$ as $\left.\mathrm{CaCO}_{3}\right)$ & 31 & 3,700 & 45 & 430 & 250 \\
\hline Calcium, dissolved $(\mathrm{mg} / \mathrm{L})$ & 31 & 400 & 7.7 & 77 & 50 \\
\hline Magnesium, dissolved (mg/L) & 31 & 640 & 6.3 & 58 & 29 \\
\hline Sodium, dissolved $(\mathrm{mg} / \mathrm{L})$ & 31 & 820 & 9.2 & 190 & 160 \\
\hline Sodium adsorption ratio & 31 & 20 & 0.2 & 5.0 & 3.0 \\
\hline Potassium, dissolved (mg/L) & 31 & 12 & 2.0 & 4.7 & 3.9 \\
\hline Bicarbonate, field (mg/L as $\left.\mathrm{CaCO}_{3}\right)$ & 21 & 760 & 230 & 424 & 370 \\
\hline Alkalinity, lab or field (mg/L as $\left.\mathrm{CaCO}_{3}\right)$ & 30 & 620 & 188 & 376 & 356 \\
\hline Sulfate, dissolved (mg/L) & 30 & 4,700 & 41 & 490 & 250 \\
\hline Chloride, dissolved (mg/L) & 31 & 25 & $<1.0$ & 3.0 & 2.0 \\
\hline Fluoride, dissolved (mg/L) & 30 & 0.8 & 0.1 & 0.3 & 0.3 \\
\hline Silica, dissolved $(\mathrm{mg} / \mathrm{L})$ & 31 & 53 & 9.8 & 17 & 15 \\
\hline Dissolved solids, sum of constituents (mg/L) & 30 & 6,410 & 275 & 1,080 & 768 \\
\hline Nitrate, dissolved (mg/L as $\mathrm{N})$ & 22 & 4.7 & 0.11 & 0.44 & 0.23 \\
\hline Boron, dissolved $(\mu \mathrm{g} / \mathrm{L})$ & 20 & 2,700 & 40 & 440 & 260 \\
\hline Iron, dissolved $(\mu \mathrm{g} / \mathrm{L})$ & 31 & 21,000 & $<3$ & 1,040 & 270 \\
\hline Manganese, dissolved $(\mu \mathrm{g} / \mathrm{L})$ & 25 & 16,000 & 2 & 800 & 120 \\
\hline
\end{tabular}

\section{Bear Den Creek}

Bear Den Creek is located along the western boundary of the Reservation and flows from the north to the south and then northeastward. The stream has a drainage area of 117 square miles, of which 34 square miles are within the Reservation (fig. 35).

Streamflow data have been collected at the Bear Den Creek near Mandaree, N. Dak., gaging station since June 1966. From June 1966 through September 1992, instantaneous streamflow ranged from zero on many days to 2,840 cubic feet per second on March 13, 1972 (table 13). Mean streamflow for the 26-year period of record was 6.72 cubic feet per second, and the median was 4.89 cubic feet per second. From April 1990 through September 1992, daily mean streamflow ranged from zero on many days to 87 cubic feet per second on July 3, 1990 (fig. 36). Bear Den Creek is characterized by sudden increases in streamflow that usually last for short periods of time. These sudden increases result from short periods of intense precipitation over the basin or from rapid snowmelt conditions in early spring.

The Bear Den Creek near Mandaree, N. Dak., gaging station was the only active continuous-record gaging station on or near the Reservation that had a substantial period of record before the study. Therefore, mean monthly streamflows for the gaging station for 1990-92 were compared to monthly mean streamflow statistics for the station for 1970-92 (fig. 37). For 6 months of the year, the mean monthly streamflows for 1990-92 were less than the mean monthly streamflows for 1970-92. During the 1988-92 drought, extended periods of little or no flow occurred in streams on the Reservation. The less-thanaverage streamflow trend during 1990-92 at the Bear Den Creek near Mandaree, N. Dak., gaging station was representative of all streams on the Reservation. 


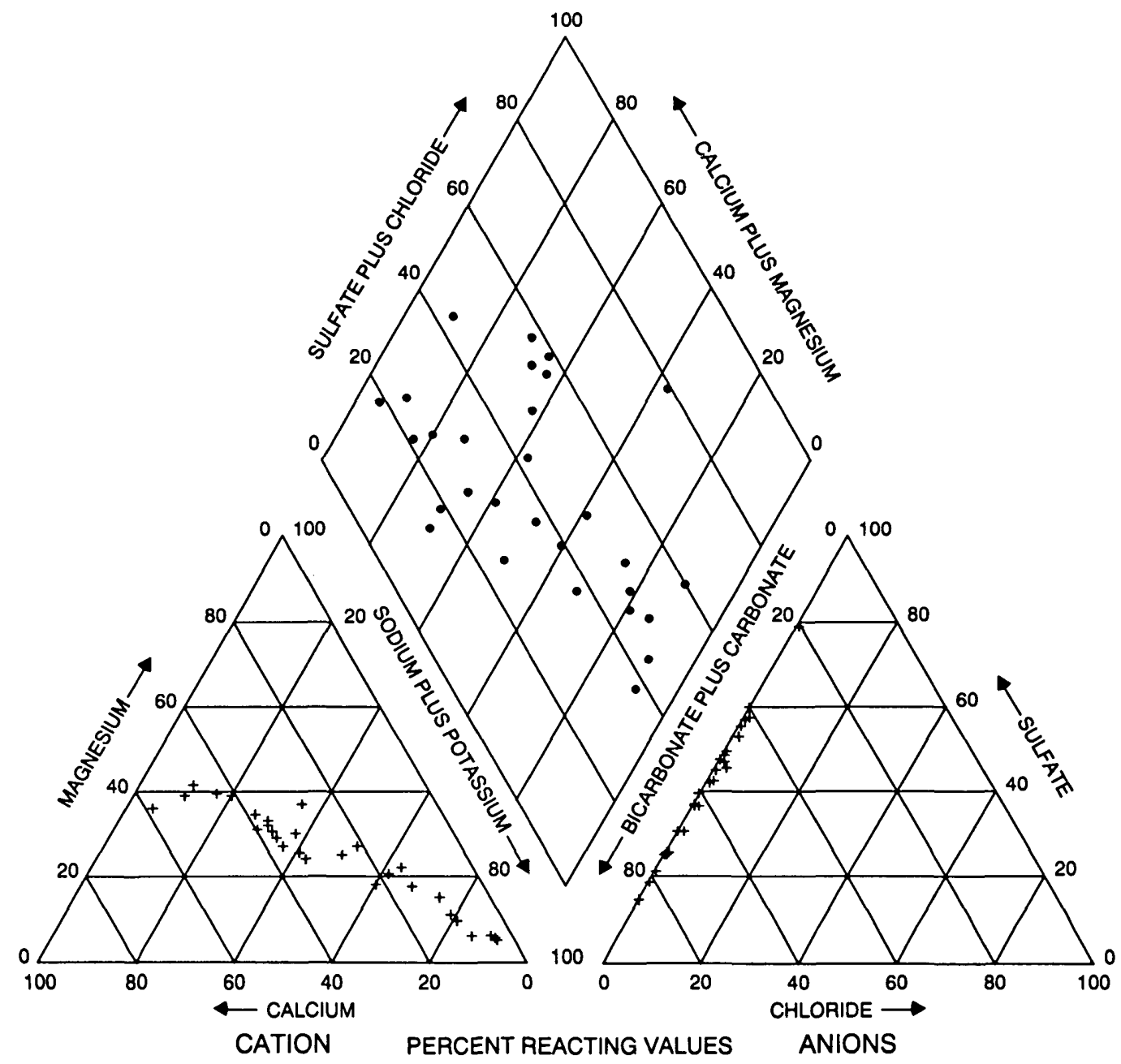

FIgure 34. Major-ion composition of water in springs on the Fort Berthold Reservation.

From April 1990 through September 1990, two streamflow measurements and six no-flow observations were made at the Bear Den Creek above mouth near Mandaree, N. Dak., miscellaneous site. Streamflow was 0.52 cubic foot per second on August 27, 1990, and 0.76 cubic foot per second on September 20, 1990 (table 13). After September 1990, streamflow measurements were made at the Bear Den Creek near Mandaree, N. Dak., gaging station located upstream from the miscellaneous site.

A statistical summary of selected water-quality data for Bear Den Creek near Mandaree, N. Dak., for April 1990 through September 1992 is given in table 14. Dissolved sulfate concentrations ranged from 310 to 1,200 milligrams per liter, and dissolved nitrite plus nitrate concentrations ranged from less than 0.10 to 0.18 milligram per liter as nitrogen.

\section{Shell Creek}

Shell Creek is located along the northern boundary of the Reservation and flows from the north to the southwest. The stream has a drainage area of 465 square miles, of which 30 square miles are within the Reservation (fig. 35). 

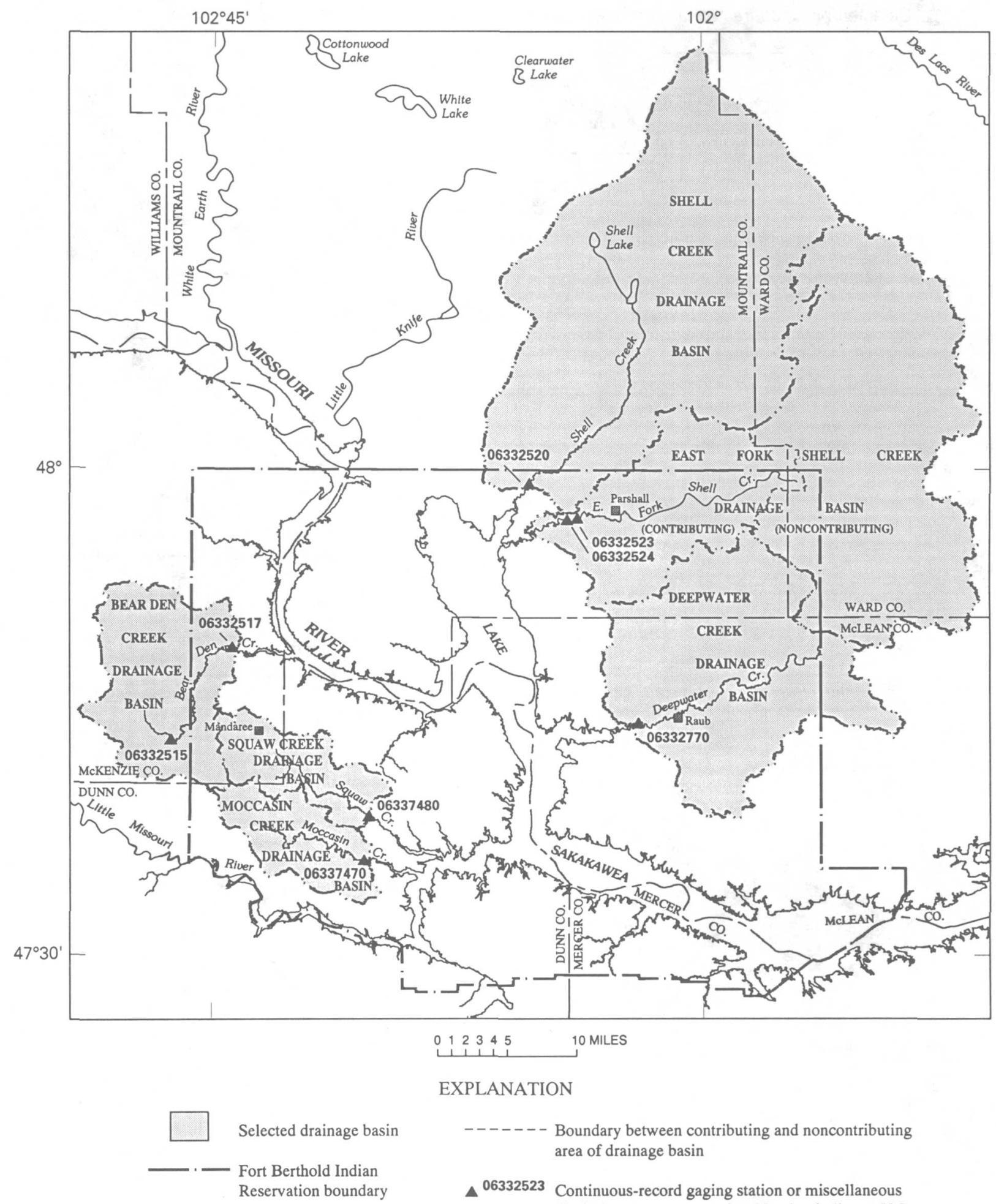
------ Boundary between contributing and noncontributing area of drainage basin
06332523 Continuous-record gaging station or miscellaneous discharge-measurement site--Number indicates U.S. Geological Survey identification

Figure 35. Locations of selected streams, drainage basins, continuous-record gaging stations, and miscellaneous discharge-measurement sites on and near the Fort Berthold Indian Reservation. 
Table 12. Selected basin characteristics for major streams on the Fort Berthold Indian Reservation

\begin{tabular}{lcccc}
\hline Stream & $\begin{array}{c}\text { Total drainage } \\
\text { area } \\
\text { (square miles) }\end{array}$ & $\begin{array}{c}\text { Stream length } \\
\text { (miles) }\end{array}$ & $\begin{array}{c}\text { Stream slope } \\
\text { (feet per mile) }\end{array}$ & $\begin{array}{c}\text { Mean basin } \\
\text { elevation } \\
\text { (feet above } \\
\text { sea level) }\end{array}$ \\
\hline Bear Den Creek & 117 & 31.2 & 15.4 & 2,317 \\
Shell Creek & 465 & 25.1 & 2.6 & 2,150 \\
East Fork Shell Creek & 467 & 150.2 & 6.3 & 12,114 \\
Deepwater Creek & 235 & 28.7 & 10.7 & 2,065 \\
Moccasin Creek & 54 & 26.6 & 18.3 & 2,248 \\
Squaw Creek & 58 & 23.4 & 12.5 & 2,212 \\
\hline
\end{tabular}

'Based on 129 square miles of contributing drainage area.

Table 13. Statistical summary of streamflow data for selected continuous-record gaging stations and selected miscellaneous discharge-measurement sites on and adjacent to the Fort Berthold Indian Reservation

$[--$, not computed because of limited data]

\begin{tabular}{|c|c|c|c|c|c|}
\hline \multirow{2}{*}{$\begin{array}{l}\text { Station or site } \\
\text { name and } \\
\text { number }\end{array}$} & \multirow{2}{*}{$\begin{array}{l}\text { Period of } \\
\text { record }\end{array}$} & \multicolumn{2}{|c|}{$\begin{array}{c}\text { Instantaneous streamflow for } \\
\text { period of record } \\
\text { (cubic feet per second) }\end{array}$} & \multicolumn{2}{|c|}{$\begin{array}{l}\text { Daily streamflow for } \\
\text { period of record } \\
\text { (cubic feet per second) }\end{array}$} \\
\hline & & Maximum & Minimum & Mean & Median \\
\hline $\begin{array}{l}\text { Bear Den Creek near } \\
\text { Mandaree, North Dakota } \\
(06332515)\end{array}$ & $\begin{array}{l}\text { June } 1966 \text { through } \\
\text { September } 1992\end{array}$ & 2,840 & 0 & 6.72 & 4.89 \\
\hline $\begin{array}{l}\text { Bear Den Creek above mouth } \\
\text { near Mandaree, North } \\
\text { Dakota }(06332517)\end{array}$ & $\begin{array}{l}\text { April } 1990 \text { through } \\
\text { September } 1990\end{array}$ & .76 & 0 & -- & -- \\
\hline $\begin{array}{l}\text { Shell Creek near Parshall, } \\
\text { North Dakota }(06332520)\end{array}$ & $\begin{array}{l}\text { September } 1965 \\
\text { through } \\
\text { September } 1981\end{array}$ & 2,400 & 0 & 12.9 & 9.97 \\
\hline $\begin{array}{l}\text { East Fork Shell Creek near } \\
\text { Parshall, North Dakota } \\
(06332523)\end{array}$ & $\begin{array}{l}\text { July } 1991 \text { through } \\
\text { September } 1992\end{array}$ & 59 & 0 & -- & -- \\
\hline $\begin{array}{l}\text { East Fork Shell Creek near } \\
\text { mouth below Parshall, } \\
\text { North Dakota }(06332524)\end{array}$ & $\begin{array}{l}\text { April } 1990 \text { through } \\
\text { June } 1991\end{array}$ & 3.65 & 0 & -- & -- \\
\hline \multirow{2}{*}{$\begin{array}{l}\text { Deepwater Creek at mouth } \\
\text { near Raub, North Dakota } \\
(06332770)\end{array}$} & $\begin{array}{l}\text { April } 1990 \text { through } \\
\text { June } 1991^{1}\end{array}$ & 4.28 & 0 & -- & -- \\
\hline & $\begin{array}{l}\text { July } 1991 \text { through } \\
\text { September } 1992^{2}\end{array}$ & 50 & 0 & -- & -- \\
\hline $\begin{array}{l}\text { Moccasin Creek at mouth near } \\
\text { Mandaree, North Dakota } \\
(06337470)\end{array}$ & $\begin{array}{l}\text { April } 1990 \text { through } \\
\text { September } 1992\end{array}$ & 7.07 & 0 & - & -- \\
\hline $\begin{array}{l}\text { Squaw Creek above mouth } \\
\text { near Mandaree, North } \\
\text { Dakota }(06337480)\end{array}$ & $\begin{array}{l}\text { April } 1990 \text { through } \\
\text { September } 1992\end{array}$ & 4.22 & 0 & - & -- \\
\hline
\end{tabular}

\footnotetext{
'Period of record for miscellaneous discharge-measurement site.
}

${ }^{2}$ Period of record for continuous-record gaging station. 


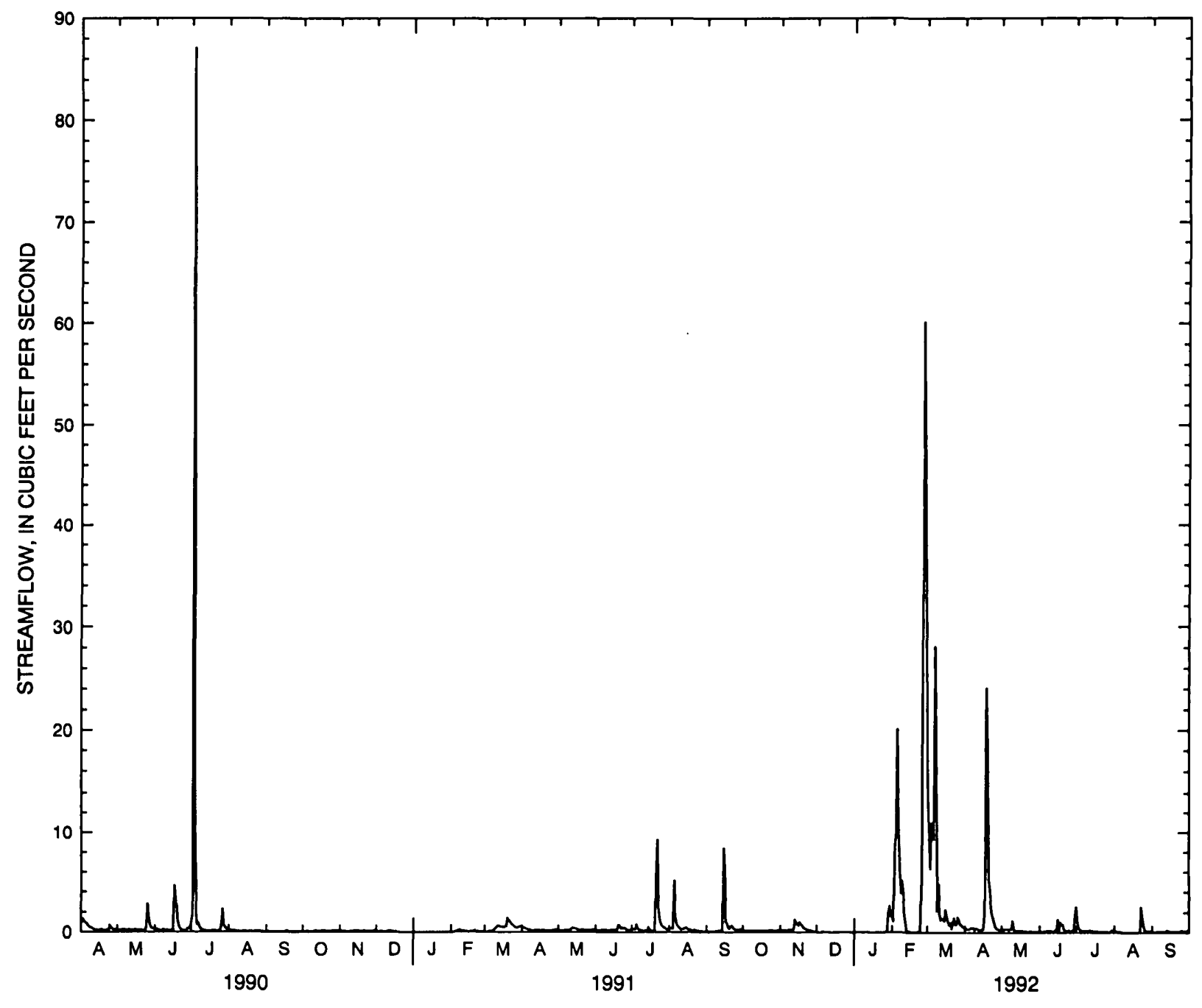

Figure 36. Daily mean streamflow at the Bear Den Creek near Mandaree, North Dakota, gaging station, April 1990 through September 1992.

Streamflow data were collected at the Shell Creek near Parshall, N. Dak., gaging station from September 1965 through September 1981. For the period of record, instantaneous streamflow ranged from zero on many days to 2,400 cubic feet per second on April 18, 1979 (table 13). Mean streamflow for the 16-year period of record was 12.9 cubic feet per second, and the median was 9.97 cubic feet per second. Daily mean streamflow ranged from zero on many days to 1,750 cubic feet per second on April 7, 1969 (fig. 38). Data collection during this study was concentrated on streams for which previous data were unavailable or limited. Because previous data were available for this site, streamflow and water-quality data were not collected during this study. However, streamflow data for September 1965 through September 1981 were included because of the size of the basin and because Shell Creek flows into the Reservation.

\section{East Fork Shell Creek}

East Fork Shell Creek is located in the northeastern corner of the Reservation and flows from the northeast to the southwest. The stream has a drainage area of 467 square miles, of which 125 square miles are within the Reservation (fig. 35). 


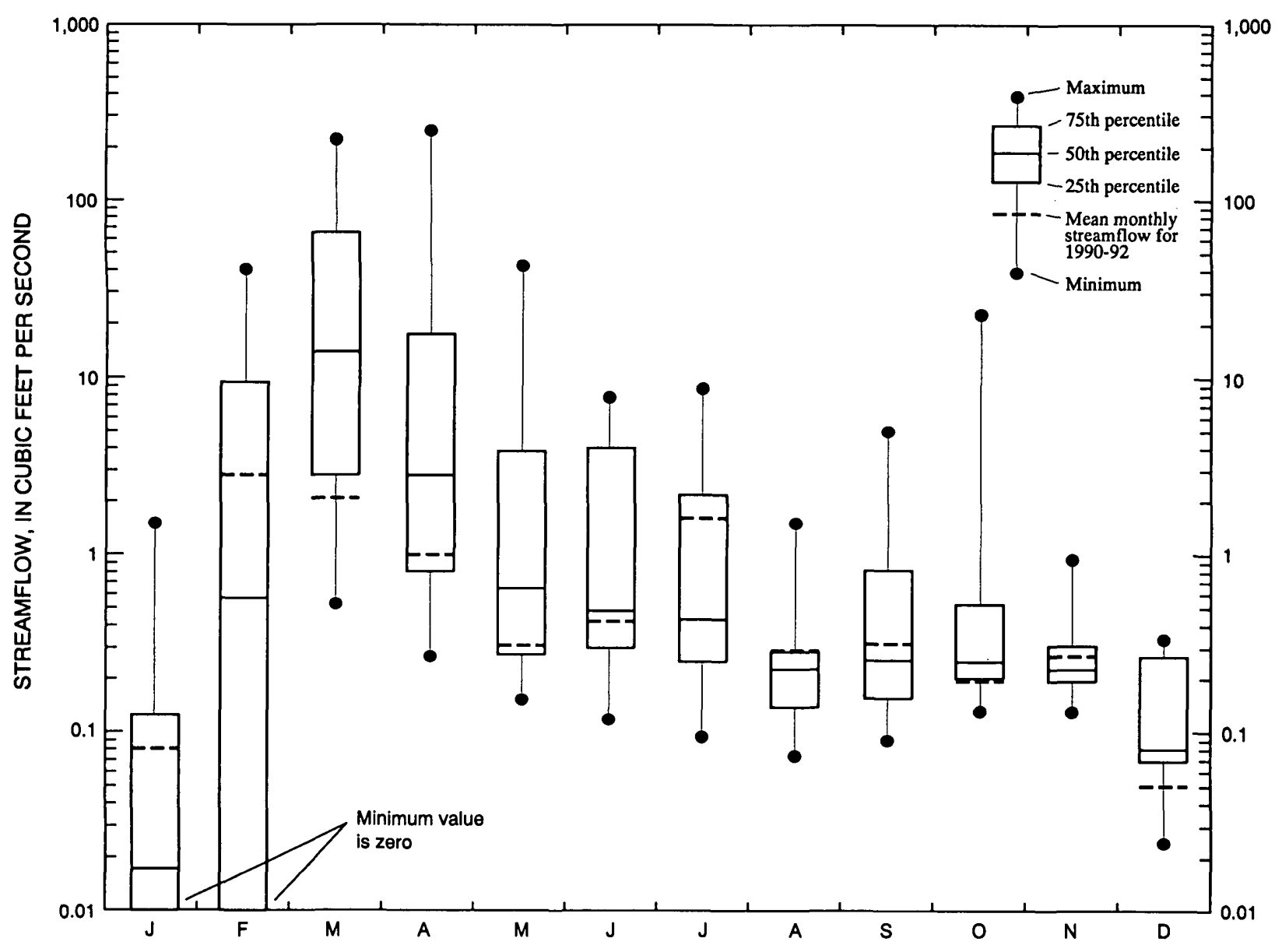

Figure 37. Monthly mean streamflow statistics, 1970-92, and mean monthly streamflow, 1990-92, at the Bear Den Creek near Mandaree, North Dakota, gaging station.

The East Fork Shell Creek near Parshall, N. Dak. (06332523), gaging station was established in June 1991. The gaging station is located 1.5 miles northeast and upstream of the miscellaneous site. From July 1991 through September 1992, instantaneous streamflow ranged from zero on many days to 59 cubic feet per second on March 1, 1992 (table 13). Daily mean streamflow ranged from zero on many days to 36 cubic feet per second on March 1, 1992 (fig. 39). The increases in streamflow are very sudden and are similar to those in Bear Den Creek, but the decreases are more gradual.

A statistical summary of selected water-quality data for East Fork Shell Creek near Parshall, N. Dak., for July 1991 through September 1992 is given in table 15. Dissolved sulfate concentrations ranged from 860 to 1,200 milligrams per liter, and dissolved nitrite plus nitrate concentrations ranged from 0.02 to 0.58 milligram per liter as nitrogen.

Streamflow was measured monthly at the East Fork Shell Creek near mouth below Parshall, N. Dak., miscellaneous site from April 1990 through June 1991. For the period of record, streamflow measurements ranged from zero in some months to 3.65 cubic feet per second on March 28, 1991 (table 13; fig. 40). However, this site was not a continuous-record station, and larger streamflows probably occurred during the period of record. 
Table 14. Statistical summary of selected water-quality data for Bear Den Creek near Mandaree, N. Dak., April 1990 through September 1992

$\left[\mu \mathrm{S} / \mathrm{cm}\right.$, microsiemens per centimeter; ${ }^{\circ} \mathrm{C}$, degrees Celsius; $\mathrm{mg} / \mathrm{L}$, milligrams per liter; --, not available; <, less than; $\mu \mathrm{g} / \mathrm{L}$, micrograms per liter]

\begin{tabular}{|c|c|c|c|c|}
\hline $\begin{array}{l}\text { Physical property or } \\
\text { chemical constituent }\end{array}$ & $\begin{array}{l}\text { Number of } \\
\text { samples }\end{array}$ & Maximum & Minimum & Median \\
\hline Specific conductance $\left(\mu \mathrm{S} / \mathrm{cm}\right.$ at $\left.25^{\circ} \mathrm{C}\right)$ & 58 & 3,500 & 875 & 2,260 \\
\hline $\mathrm{pH}$, field (standard units) & 45 & 8.9 & 8.0 & 8.4 \\
\hline Oxygen, dissolved (mg/L) & 45 & 14.1 & 6.4 & 12.0 \\
\hline Hardness, total $\left(\mathrm{mg} / \mathrm{L}\right.$ as $\left.\mathrm{CaCO}_{3}\right)$ & 17 & 250 & 100 & 180 \\
\hline Calcium, dissolved (mg/L) & 17 & 49 & 18 & 34 \\
\hline Magnesium, dissolved (mg/L) & 17 & 35 & 9.5 & 25 \\
\hline Sodium, dissolved $(\mathrm{mg} / \mathrm{L})$ & 17 & 820 & 240 & 570 \\
\hline Sodium adsorption ratio & 17 & 24 & 10 & 19 \\
\hline Potassium, dissolved $(\mathrm{mg} / \mathrm{L})$ & 17 & 11 & 4.8 & 6.0 \\
\hline Bicarbonate, dissolved $\left(\mathrm{mg} / \mathrm{L}\right.$ as $\left.\mathrm{HCO}_{3}\right)$ & 16 & 1,170 & 349 & 824 \\
\hline Carbonate, dissolved $\left(\mathrm{mg} / \mathrm{L}\right.$ as $\left.\mathrm{CO}_{3}\right)$ & 16 & 96 & 0 & 35 \\
\hline Alkalinity, total $\left(\mathrm{mg} / \mathrm{L}\right.$ as $\left.\mathrm{CaCO}_{3}\right)$ & 17 & 1,050 & 328 & 747 \\
\hline Alkalinity, dissolved $\left(\mathrm{mg} / \mathrm{L}\right.$ as $\left.\mathrm{CaCO}_{3}\right)$ & 16 & 1,080 & 306 & 744 \\
\hline Sulfate, dissolved $(\mathrm{mg} / \mathrm{L})$ & 17 & 1,200 & 310 & 650 \\
\hline Chloride, dissolved (mg/L) & 17 & 64 & $<0.1$ & 6.0 \\
\hline Dissolved solids, residue at $180^{\circ} \mathrm{C}(\mathrm{mg} / \mathrm{L})$ & 16 & 2,530 & 792 & 1,785 \\
\hline Dissolved solids, sum of constituents $(\mathrm{mg} / \mathrm{L}$ ) & 16 & 2,500 & 789 & 1,825 \\
\hline Nitrate, total $(\mathrm{mg} / \mathrm{L}$ as $\mathrm{N})$ & 2 & 0.130 & 0.048 & -- \\
\hline Nitrate, dissolved ( $\mathrm{mg} / \mathrm{L}$ as $\mathrm{N}$ ) & 4 & 0.160 & 0.036 & -- \\
\hline Nitrite, total $(\mathrm{mg} / \mathrm{L}$ as $\mathrm{N})$ & 13 & 0.050 & $<0.010$ & 0.020 \\
\hline Nitrite, dissolved (mg/L as $\mathrm{N}$ ) & 16 & 0.020 & $<0.010$ & 0.006 \\
\hline Nitrite plus nitrate, total (mg/L as $\mathrm{N})$ & 13 & 0.17 & $<0.10$ & $<0.10$ \\
\hline Nitrite plus nitrate, dissolved ( $\mathrm{mg} / \mathrm{L}$ as $\mathrm{N}$ ) & 17 & 0.18 & $<0.10$ & $<0.10$ \\
\hline Nitrogen, ammonia, dissolved (mg/L as $\mathrm{N}$ ) & 16 & 0.380 & 0.010 & 0.025 \\
\hline $\begin{array}{l}\text { Nitrogen, ammonia plus organic, total } \\
\quad(\mathrm{mg} / \mathrm{L} \text { as } \mathrm{N})\end{array}$ & 16 & 1.2 & 0.3 & 0.7 \\
\hline $\begin{array}{l}\text { Nitrogen, ammonia plus organic, dissolved } \\
\quad(\mathrm{mg} / \mathrm{L} \text { as } \mathrm{N})\end{array}$ & 1 & 0.9 & -- & -- \\
\hline Nitrogen, organic, total (mg/L as $\mathrm{N})$ & 15 & 1.1 & 0.28 & 0.56 \\
\hline Nitrogen, organic, dissolved ( $\mathrm{mg} / \mathrm{L}$ as $\mathrm{N})$ & 1 & 0.88 & -- & -- \\
\hline Nitrogen, total $(\mathrm{mg} / \mathrm{L}$ as $\mathrm{N})$ & 3 & 1.2 & 0.93 & -- \\
\hline Phosphorus, total (mg/L as $\mathrm{P})$ & 16 & 0.210 & 0.040 & 0.075 \\
\hline Phosphorus, dissolved (mg/L as $\mathrm{P}$ ) & 16 & 0.05 & $<0.01$ & 0.01 \\
\hline Phosphorus, ortho, total (mg/L as $\mathrm{P}$ ) & 3 & 0.07 & $<0.01$ & 0.02 \\
\hline Phosphorus, ortho, dissolved ( $\mathrm{mg} / \mathrm{L}$ as $\mathrm{P}$ ) & 17 & 0.05 & $<0.01$ & $<0.01$ \\
\hline Aluminum, dissolved $(\mu \mathrm{g} / \mathrm{L})$ & 11 & 480 & $<10$ & 60 \\
\hline Arsenic, dissolved $(\mu \mathrm{g} / \mathrm{L})$ & 6 & 4 & $<1$ & 2 \\
\hline Barium, dissolved $(\mu \mathrm{g} / \mathrm{L})$ & 11 & $<100$ & $<100$ & $<100$ \\
\hline Beryllium, dissolved $(\mu \mathrm{g} / \mathrm{L})$ & 6 & $<10$ & $<10$ & $<10$ \\
\hline Cadmium, dissolved $(\mu \mathrm{g} / \mathrm{L})$ & 6 & $<1$ & $<1$ & $<1$ \\
\hline Chromium, dissolved $(\mu \mathrm{g} / \mathrm{L})$ & 6 & $<1$ & $<1$ & $<1$ \\
\hline Cobalt, dissolved $(\mu \mathrm{g} / \mathrm{L})$ & 11 & 4 & $<1$ & 1 \\
\hline
\end{tabular}


Table 14. Statistical summary of selected water-quality data for Bear Den Creek near Mandaree, N. Dak., April 1990 through September 1992-Continued

$\left[\mu \mathrm{S} / \mathrm{cm}\right.$, microsiemens per centimeter; ${ }^{\circ} \mathrm{C}$, degrees Celsius; $\mathrm{mg} / \mathrm{L}$, milligrams per liter; --, not available; <, less than; $\mu \mathrm{g} / \mathrm{L}$, micrograms per liter]

\begin{tabular}{lcccc}
\hline \multicolumn{1}{c}{$\begin{array}{c}\text { Physical property or } \\
\text { chemical constituent }\end{array}$} & $\begin{array}{c}\text { Number of } \\
\text { samples }\end{array}$ & Maximum & Minimum & Median \\
\hline Copper, dissolved $(\mu \mathrm{g} / \mathrm{L})$ & 6 & 5.0 & 1.0 & 2.5 \\
Iron, dissolved $(\mu \mathrm{g} / \mathrm{L})$ & 12 & 420 & 20 & 70 \\
Lead, dissolved $(\mu \mathrm{g} / \mathrm{L})$ & 6 & $<1$ & $<1$ & $<1$ \\
Lithium, dissolved $(\mu \mathrm{g} / \mathrm{L})$ & 11 & 80 & 24 & 60 \\
Manganese, dissolved $(\mu \mathrm{g} / \mathrm{L})$ & 12 & 460 & $<10$ & 70 \\
& & & & $<0.1$ \\
Mercury, dissolved $(\mu \mathrm{g} / \mathrm{L})$ & 6 & $<0.1$ & $<1$ & $<$ \\
Molybdenum, dissolved $(\mu \mathrm{g} / \mathrm{L})$ & 11 & 3 & $<1$ & 4 \\
Nickel, dissolved $(\mu \mathrm{g} / \mathrm{L})$ & 11 & $<$ & $<1$ & $<1$ \\
Selenium, dissolved $(\mu \mathrm{g} / \mathrm{L})$ & 11 & $<1$ & $<1$ & $<1$ \\
Silver, dissolved $(\mu \mathrm{g} / \mathrm{L})$ & 11 & & & 380 \\
& 11 & 470 & 260 & 4 \\
Strontium, dissolved $(\mu \mathrm{g} / \mathrm{L})$ & 11 & 16 & $<6$ & $<10$ \\
Vanadium, dissolved $(\mu \mathrm{g} / \mathrm{L})$ & 6 & $<10$ & $<10$ & \\
Zinc, dissolved $(\mu \mathrm{g} / \mathrm{L})$ & & & & \\
& & & & \\
\hline
\end{tabular}

A statistical summary of selected water-quality data for East Fork Shell Creek near mouth below Parshall, N. Dak., for April 1990 through June 1991 is given in table 16. Dissolved sulfate concentrations ranged from 750 to 1,300 milligrams per liter, and dissolved nitrite plus nitrate concentrations ranged from less than 0.05 to less than 0.10 milligram per liter as nitrogen.

\section{Deepwater Creek}

Deepwater Creek is located along the eastern side of the Reservation and flows from the north to the southwest. The stream has a drainage area of 235 square miles, of which 212 square miles are within the Reservation (fig. 35).

Streamflow was measured monthly at the Deepwater Creek at mouth near Raub, N. Dak., miscellaneous site from April 1990 through May 1991. For the period of record, streamflow measurements ranged from zero on many days to 4.28 cubic feet per second on March 28, 1991 (table 13; fig. 41). However, this site was not a continuous-record station, and larger streamflows probably occurred during the period of record.

The Deepwater Creek at mouth near Raub, N. Dak., gaging station was established at the same site in June 1991. From July 1991 through September 1992, instantaneous streamflow ranged from zero on many days to 50 cubic feet per second on February 29, 1992 (table 13). Daily mean streamflow ranged from zero on many days to 40 cubic feet per second on February 29, 1992 (fig. 42). The streamflow pattern for Deepwater Creek is similar to that for East Fork Shell Creek.

A statistical summary of selected water-quality data for Deepwater Creek at mouth near Raub, N. Dak., for April 1990 through September 1992 is given in table 17. Dissolved sulfate concentrations ranged from 350 to 920 milligrams per liter, and dissolved nitrite plus nitrate concentrations ranged from less than 0.05 to 0.36 milligram per liter as nitrogen. 


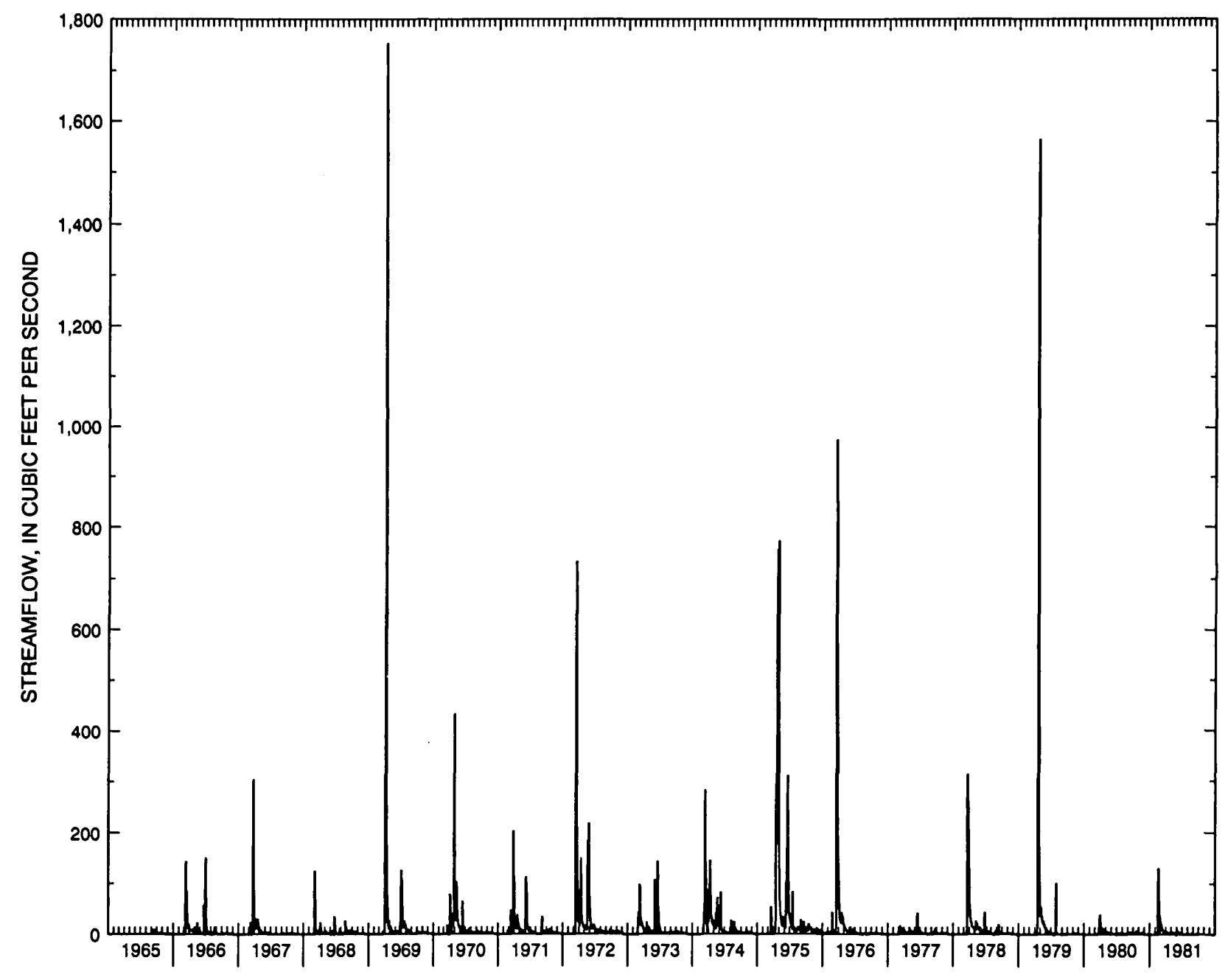

Figure 38. Daily mean streamflow at the Shell Creek near Parshall, North Dakota, gaging station, September 1965 through September 1981.

\section{Moccasin Creek}

Moccasin Creek is located in the southwestern corner of the Reservation and flows from the northwest to the southeast. The stream has a drainage area of 54 square miles, all of which lie within the Reservation (fig. 35).

Streamflow was measured monthly at the Moccasin Creek at mouth near Mandaree, N. Dak., miscellaneous site from April 1990 through September 1992. For the period of record, streamflow measurements ranged from zero on many days to 7.07 cubic feet per second on January 10, 1992 (table 13; fig. 43). However, this site was not a continuous-record station, and larger streamflows probably occurred during the period of record.

Because of the long periods without flow caused by the 1988-92 drought, only two water samples were collected at this site during the study. A statistical summary of selected water-quality data for Moccasin Creek at mouth near Mandaree, N. Dak., for April 1990 through September 1992 is given in table 18. Dissolved sulfate concentrations were 310 and 450 milligrams per liter, and dissolved nitrite plus nitrate concentrations were less than 0.05 milligram per liter as nitrogen. 


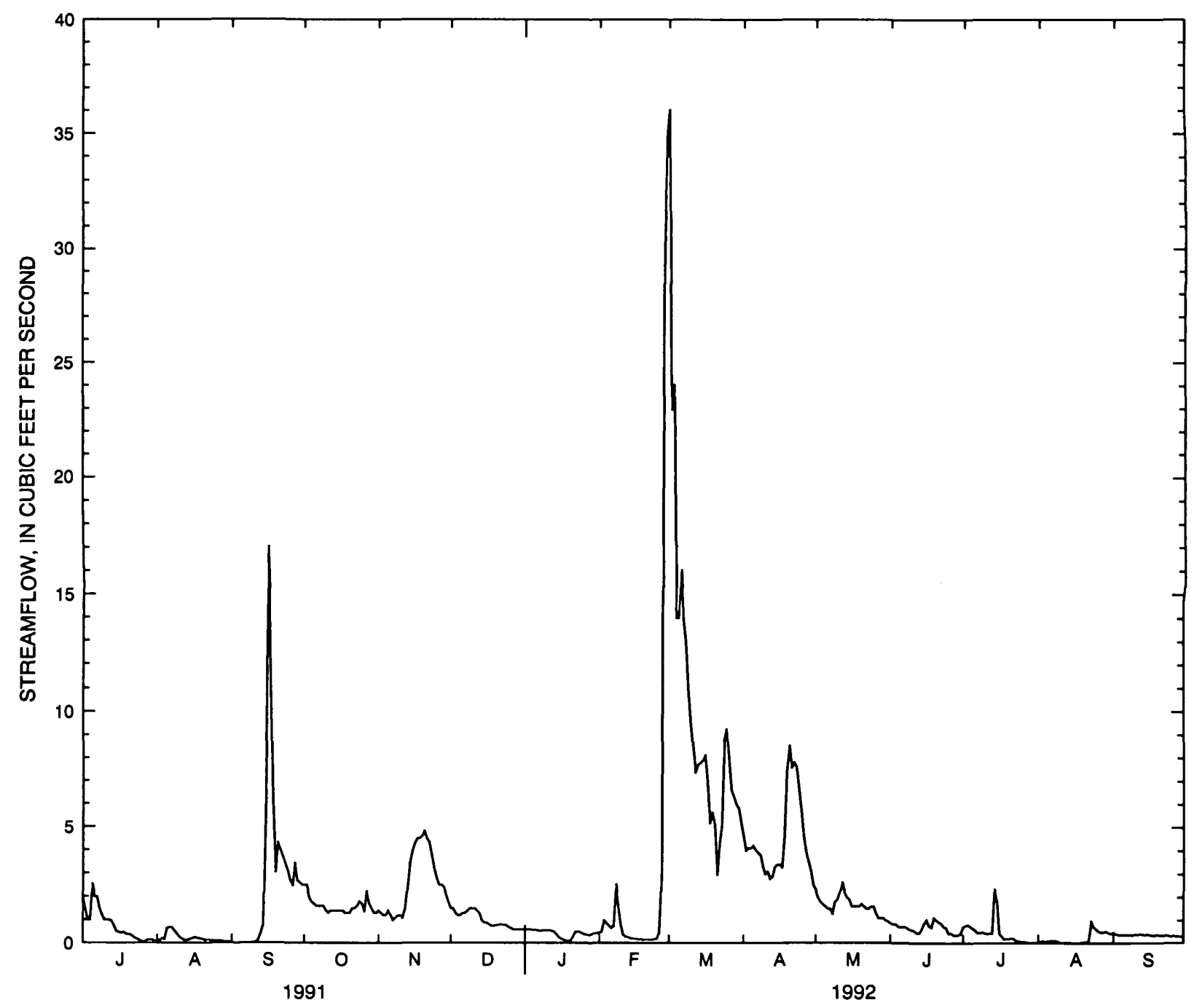

Figure 39. Daily mean streamflow at the East Fork Shell Creek near Parshall, North Dakota, gaging station, July 1991 through September 1992.

\section{Squaw Creek}

Squaw Creek is located in the southwestern corner of the Reservation and flows from the northwest to the southeast. The stream has a drainage area of 58 square miles, all of which lie within the Reservation (fig. 35).

Streamflow was measured monthly at the Squaw Creek above mouth near Mandaree, N. Dak., miscellaneous site from April 1990 through September 1992. For the period of record, streamflow measurements ranged from zero on many days to 4.22 cubic feet per second on February 27, 1992 (table 13; fig. 44). However, this site was not a continuous-record station, and larger streamflows probably occurred during the period of record.

Because of the long periods without flow caused by the 1988-92 drought, only two water samples were collected at this site during the study. A statistical summary of selected water-quality data for Squaw Creek above mouth near Mandaree, N. Dak., for April 1990 through September 1992 is given in table 19. 
Dissolved sulfate concentrations were 2,300 and 2,400 milligrams per liter, and dissolved nitrite plus nitrate concentrations were less than 0.05 milligram per liter as nitrogen.

Table 15. Statistical summary of selected water-quality data for East Fork Shell Creek near Parshall, N. Dak., July 1991 through September 1992

$\left[\mu \mathrm{S} / \mathrm{cm}\right.$, microsiemens per centimeter; ${ }^{\circ} \mathrm{C}$, degrees Celsius; $\mathrm{mg} / \mathrm{L}$, milligrams per liter; $<$, less than; $\mu \mathrm{g} / \mathrm{L}$, micrograms per liter]

\begin{tabular}{|c|c|c|c|c|}
\hline $\begin{array}{l}\text { Physical property or } \\
\text { chemical constituent }\end{array}$ & $\begin{array}{l}\text { Number of } \\
\text { samples }\end{array}$ & Maximum & Minimum & Median \\
\hline Specific conductance $\left(\mu \mathrm{S} / \mathrm{cm}\right.$ at $\left.25^{\circ} \mathrm{C}\right)$ & 12 & 3,820 & 1,070 & 3,340 \\
\hline $\mathrm{pH}$, field (standard units) & 7 & 9.1 & 8.1 & 8.7 \\
\hline Oxygen, dissolved (mg/L) & 7 & 11.6 & 4.6 & 6.8 \\
\hline Hardness, total $\left(\mathrm{mg} / \mathrm{L}\right.$ as $\left.\mathrm{CaCO}_{3}\right)$ & 7 & 470 & 250 & 350 \\
\hline Calcium, dissolved (mg/L) & 7 & 73 & 22 & 37 \\
\hline Magnesium, dissolved (mg/L) & 7 & 73 & 47 & 63 \\
\hline Sodium, dissolved (mg/L) & 7 & 820 & 580 & 670 \\
\hline Percent sodium & 7 & 85 & 72 & 81 \\
\hline Sodium adsorption ratio & 7 & 19 & 12 & 16 \\
\hline Potassium, dissolved (mg/L) & 7 & 11 & 9.0 & 9.4 \\
\hline Alkalinity, dissolved $\left(\mathrm{mg} / \mathrm{L}\right.$ as $\left.\mathrm{CaCO}_{3}\right)$ & 7 & 909 & 661 & 768 \\
\hline Sulfate, dissolved $(\mathrm{mg} / \mathrm{L})$ & 7 & 1,200 & 860 & 1,100 \\
\hline Chloride, dissolved (mg/L) & 7 & 52 & 4.8 & 27 \\
\hline Fluoride, dissolved (mg/L) & 7 & 1.0 & 0.3 & 0.5 \\
\hline Silica, dissolved $(\mathrm{mg} / \mathrm{L})$ & 7 & 23 & 0.7 & 6.5 \\
\hline Dissolved solids, residue at $180^{\circ} \mathrm{C}(\mathrm{mg} / \mathrm{L})$ & 7 & 2,720 & 2,160 & 2,410 \\
\hline Dissolved solids, sum of constituents ( $\mathrm{mg} / \mathrm{L}$ ) & 7 & 2,650 & 2,120 & 2,280 \\
\hline Nitrite, dissolved (mg/L as $\mathrm{N})$ & 7 & 0.020 & $<0.010$ & $<0.010$ \\
\hline Nitrite plus nitrate, dissolved (mg/L as $\mathrm{N}$ ) & 7 & 0.58 & 0.02 & 0.04 \\
\hline Nitrogen, ammonia, dissolved (mg/L) & 7 & $<10$ & $<10$ & $<10$ \\
\hline Phosphorus, ortho, total (mg/L as P) & 7 & 0.44 & 0.02 & 0.12 \\
\hline Arsenic, dissolved $(\mu \mathrm{g} / \mathrm{L})$ & 7 & 9 & 2 & 7 \\
\hline Boron, dissolved $(\mu \mathrm{g} / \mathrm{L})$ & 7 & 790 & 70 & 710 \\
\hline Iron, dissolved $(\mu \mathrm{g} / \mathrm{L})$ & 7 & 110 & 30 & 40 \\
\hline Lead, dissolved $(\mu \mathrm{g} / \mathrm{L})$ & 7 & $<1$ & $<1$ & $<1$ \\
\hline Lithium, dissolved $(\mu \mathrm{g} / \mathrm{L})$ & 7 & 170 & 120 & 140 \\
\hline Manganese, dissolved $(\mu \mathrm{g} / \mathrm{L})$ & 7 & 280 & 10 & 30 \\
\hline Mercury, dissolved $(\mu \mathrm{g} / \mathrm{L})$ & 7 & 0.02 & $<0.1$ & $<0.01$ \\
\hline Molybdenum, dissolved $(\mu \mathrm{g} / \mathrm{L})$ & 7 & 2 & $<1$ & 1 \\
\hline Selenium, dissolved $(\mu \mathrm{g} / \mathrm{L})$ & 7 & $<1$ & $<1$ & $<1$ \\
\hline Strontium, dissolved $(\mu \mathrm{g} / \mathrm{L})$ & 7 & 1,500 & 520 & 840 \\
\hline
\end{tabular}

\section{Flow in Ungaged Streams}

A multiple stepwise-regression equation was developed to estimate mean annual streamflow for ungaged streams on the Reservation. The equation was based on streamflow data from 18 gaging stations on or within a 110-mile radius of the Reservation. The equation is

$$
Q=a+b_{1} x_{1} \ldots b_{n} x_{n}
$$


where

$Q$ is mean annual streamflow, in cubic feet per second;

$a$ is a multiple regression constant;

$b_{1} \ldots b_{n}$ are regression coefficients; and

$x_{1} \ldots x_{n}$ are basin or climatic characteristics.

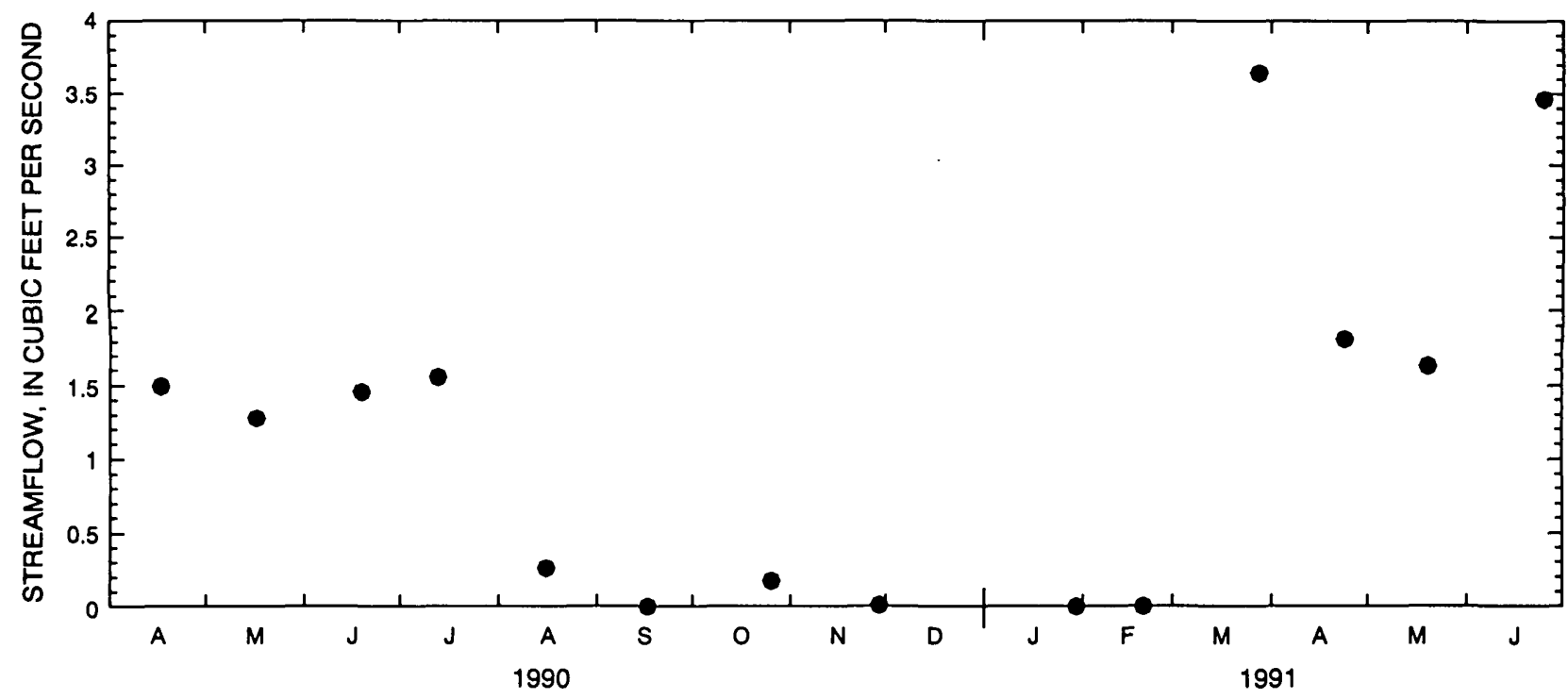

Figure 40. Streamflow measurements at the East Fork Shell Creek near mouth below Parshall, North Dakota, miscellaneous discharge-measurement site, April 1990 through June 1991.

A multiple stepwise-regression analysis was used to relate streamflow (the dependent variable) to a set of basin and climatic characteristics (the independent variables). The analysis included all basin and climatic characteristics that contributed significantly to streamflow and excluded those characteristics that had little effect on streamflow. The characteristics evaluated were drainage area, main channel slope, stream length, mean basin elevation, mean annual precipitation, and mean annual snowfall. These characteristics were computed using methods discussed by Thomas and Benson (1970).

The only basin and climatic characteristic that was significant at the 95-percent confidence level was drainage area. Some characteristics, such as mean annual precipitation, had little or no variability over the entire area of consideration and, thus, had no effect on the outcome of the regression.

The final regression equation was

$$
Q=-0.820611+0.0765738 D A
$$

where

$D A$ is the drainage area for a stream, in square miles.

The regression correlation is measured by the multiple $\mathrm{R}$-squared value. The closer this value is to 1.0 , the better the correlation. The multiple R-squared value for the final regression equation was 0.9778 , indicating a good correlation. 
Table 16. Statistical summary of selected water-quality data for East Fork Shell Creek near mouth below Parshall, N. Dak., April 1990 through June 1991

$\left[\mu \mathrm{S} / \mathrm{cm}\right.$, microsiemens per centimeter; ${ }^{\circ} \mathrm{C}$, degrees Celsius; $\mathrm{mg} / \mathrm{L}$, milligrams per liter; --, not available; <, less than; $\mu \mathrm{g} / \mathrm{L}$, micrograms per liter]

\begin{tabular}{|c|c|c|c|c|}
\hline $\begin{array}{l}\text { Physical property or } \\
\text { chemical constituent }\end{array}$ & $\begin{array}{l}\text { Number of } \\
\text { samples }\end{array}$ & Maximum & Minimum & Median \\
\hline Specific conductance $\left(\mu \mathrm{S} / \mathrm{cm}\right.$ at $\left.25^{\circ} \mathrm{C}\right)$ & 11 & 4,620 & 1,830 & 3,020 \\
\hline $\mathrm{pH}$, field (standard units) & 11 & 9.9 & 8.4 & 8.9 \\
\hline Oxygen, dissolved (mg/L) & 2 & 10.8 & 7.3 & -- \\
\hline Hardness, total $\left(\mathrm{mg} / \mathrm{L}\right.$ as $\left.\mathrm{CaCO}_{3}\right)$ & 2 & 420 & 240 & -- \\
\hline Calcium, dissolved (mg/L) & 2 & 46 & 20 & -- \\
\hline Magnesium, dissolved (mg/L) & 2 & 74 & 45 & -- \\
\hline Sodium, dissolved $(\mathrm{mg} / \mathrm{L})$ & 2 & 740 & 530 & -- \\
\hline Sodium adsorption ratio & 2 & 16 & 15 & -- \\
\hline Potassium, dissolved (mg/L) & 2 & 14 & 11 & -- \\
\hline Alkalinity, dissolved $\left(\mathrm{mg} / \mathrm{L}\right.$ as $\mathrm{CaCO}_{3}$ ) & 2 & 775 & 665 & -- \\
\hline Sulfate, dissolved (mg/L) & 2 & 1,300 & 750 & -- \\
\hline Chloride, dissolved $(\mathrm{mg} / \mathrm{L})$ & 2 & 41 & 17 & -- \\
\hline Fluoride, dissolved (mg/L) & 2 & 0.8 & 0.5 & -- \\
\hline Silica, dissolved $(\mathrm{mg} / \mathrm{L})$ & 2 & 7.2 & 1.2 & -- \\
\hline Nitrite plus nitrate, dissolved (mg/L as $\mathrm{N}$ ) & 2 & $<0.10$ & $<0.05$ & -- \\
\hline Phosphorus, ortho, dissolved (mg/L as $\mathrm{P}$ ) & 1 & 0.11 & -- & -. \\
\hline Iron, dissolved $(\mu \mathrm{g} / \mathrm{L})$ & 2 & 60 & 30 & -- \\
\hline Manganese, dissolved $(\mu \mathrm{g} / \mathrm{L})$ & 2 & 30 & 30 & -- \\
\hline
\end{tabular}

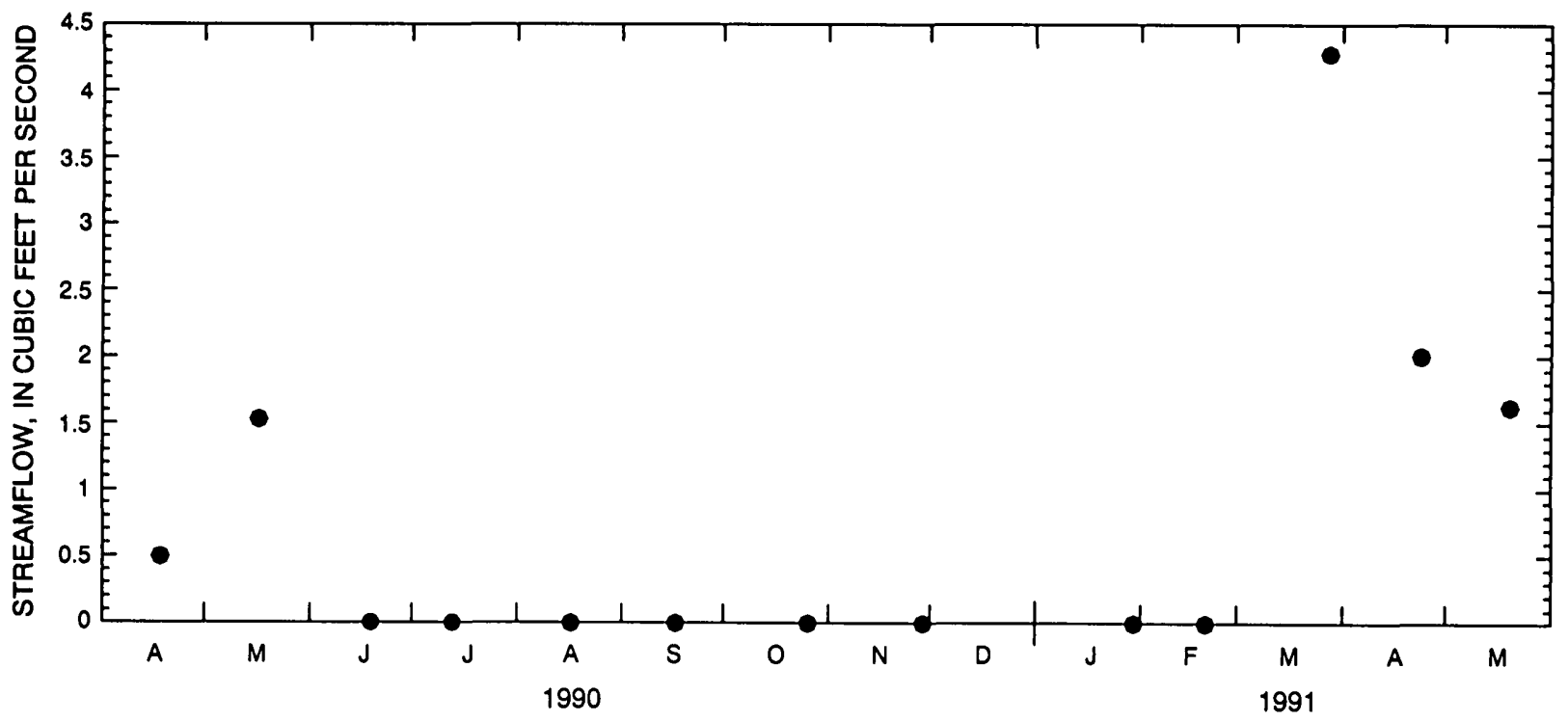

Figure 41. Streamflow measurements at the Deepwater Creek at mouth near Raub, North Dakota, miscellaneous discharge-measurement site, April 1990 through May 1991. 


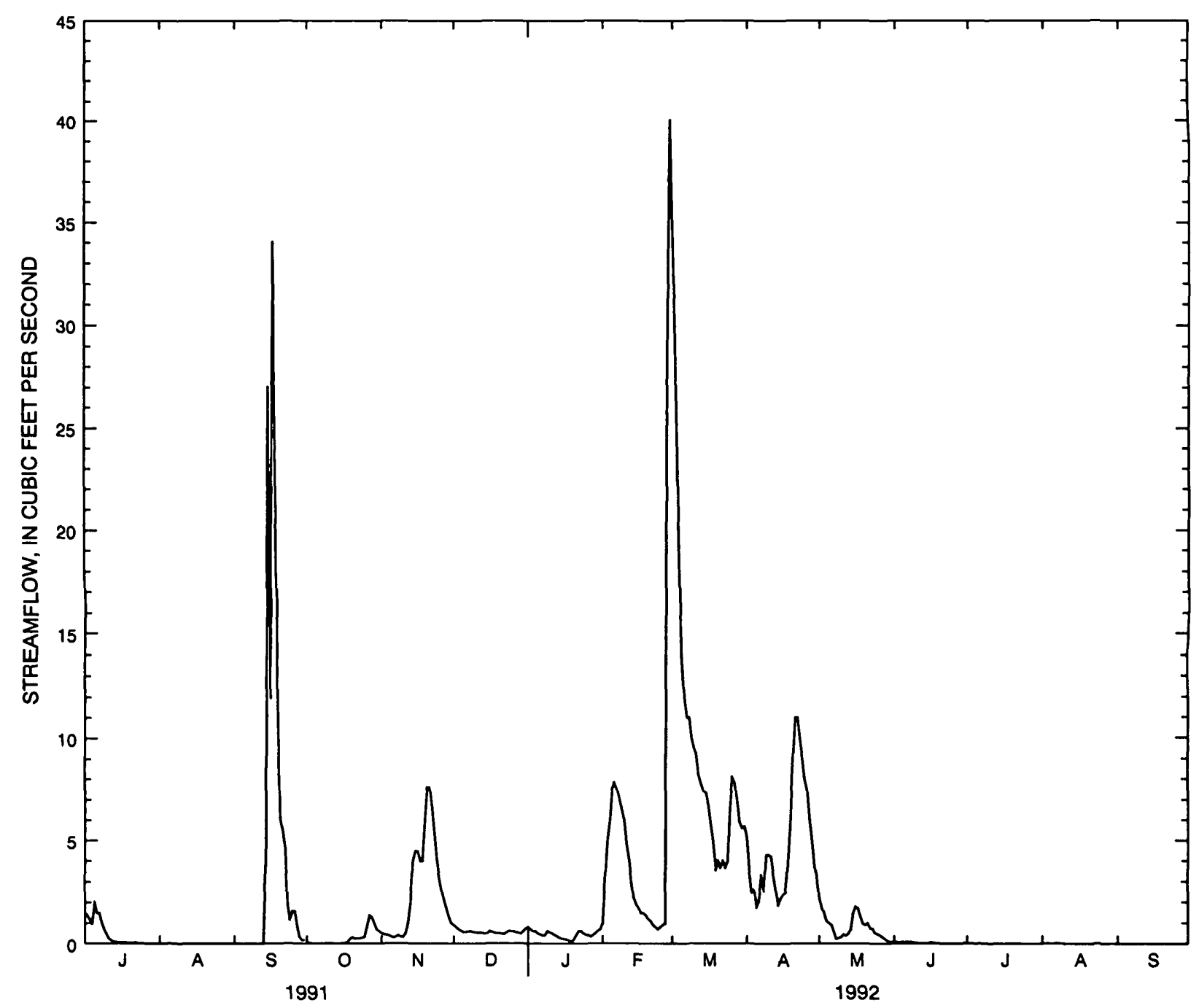

Figure 42. Daily mean streamflow at the Deepwater Creek at mouth near Raub, North Dakota, gaging station, July 1991 through September 1992.

Because flooding can cause loss of life and damage to land and structures, peak-flow frequency estimates can be very useful. Williams-Sether (1992) determined peak flows for Bear Den Creek and Shell Creek (table 20). To determine peak flows in ungaged streams, Williams-Sether (1992) developed regional regression equations that relate peak flows for selected recurrence intervals to selected basin characteristics. The equation for a 10 -year recurrence interval is

$$
Q_{10}=32.7 C A^{(0.716)} S^{(0.294)}
$$

where

$Q_{10}$ is peak flow for the 10 -year recurrence interval, in cubic feet per second;

$C A$ is contributing drainage area, in square miles; and

$S$ is main channel slope, in feet per mile; 
the equation for a 50 -year recurrence interval is

$$
Q_{50}=76.4 C A^{(0.715)} S^{(0.262)}
$$

and the equation for a 100 -year recurrence interval is

$$
Q_{100}=101 C A^{(0.713)} S^{(0.249)} .
$$

These regression equations were used to estimate peak flows for the other major streams on the Fort Berthold Indian Reservation (table 20).

Table 17. Statistical summary of selected water-quality data for Deepwater Creek at mouth near Raub, N. Dak., April 1990 through September 1992

\begin{tabular}{|c|c|c|c|c|}
\hline $\begin{array}{l}\text { Physical property or } \\
\text { chemical constituent }\end{array}$ & $\begin{array}{l}\text { Number of } \\
\text { samples }\end{array}$ & Maximum & Minimum & Median \\
\hline Specific conductance $\left(\mu \mathrm{S} / \mathrm{cm}\right.$ at $\left.25^{\circ} \mathrm{C}\right)$ & 18 & 3,180 & 713 & 2,265 \\
\hline $\mathrm{pH}$, field (standard units) & 13 & 9.6 & 8.2 & 8.7 \\
\hline Oxygen, dissolved (mg/L) & 12 & 11.6 & 4.9 & 8.4 \\
\hline Hardness, total $\left(\mathrm{mg} / \mathrm{L}\right.$ as $\left.\mathrm{CaCO}_{3}\right)$ & 5 & 630 & 280 & - \\
\hline Calcium, dissolved (mg/L) & 5 & 100 & 26 & -- \\
\hline Magnesium, dissolved (mg/L) & 5 & 93 & 40 & -- \\
\hline Sodium, dissolved (mg/L) & 5 & 510 & 210 & -- \\
\hline Sodium adsorption ratio & 5 & 10 & 5.0 & -- \\
\hline Potassium, dissolved (mg/L) & 5 & 12 & 7.1 & -- \\
\hline Alkalinity, dissolved $\left(\mathrm{mg} / \mathrm{L}\right.$ as $\left.\mathrm{CaCO}_{3}\right)$ & 5 & 802 & 367 & -- \\
\hline Sulfate, dissolved (mg/L) & 5 & 920 & 350 & -- \\
\hline Chloride, dissolved $(\mathrm{mg} / \mathrm{L})$ & 5 & 33 & 0.3 & -- \\
\hline Fluoride, dissolved $(\mathrm{mg} / \mathrm{L})$ & 5 & 0.6 & 0.1 & -- \\
\hline Silica, dissolved $(\mathrm{mg} / \mathrm{L})$ & 5 & 23 & 1.2 & -- \\
\hline Dissolved solids, residue at $180^{\circ} \mathrm{C}(\mathrm{mg} / \mathrm{L})$ & 4 & 2,080 & 920 & -- \\
\hline Dissolved solids, sum of constituents (mg/L) & 5 & 2,180 & 890 & -- \\
\hline Nitrate, dissolved ( $\mathrm{mg} / \mathrm{L}$ as $\mathrm{N})$ & 2 & 0.340 & 0.110 & -- \\
\hline Nitrite, dissolved (mg/L as $\mathrm{N})$ & 4 & 0.020 & $<0.010$ & -- \\
\hline Nitrite plus nitrate, dissolved (mg/L as $\mathrm{N})$ & 5 & 0.36 & $<0.05$ & -- \\
\hline Nitrogen, ammonia, dissolved (mg/L as $\mathrm{N})$ & 4 & 0.26 & 0.02 & -- \\
\hline Phosphorus, ortho, total (mg/L as $\mathrm{P}$ ) & 4 & 0.11 & $<0.01$ & -- \\
\hline Arsenic, dissolved $(\mu \mathrm{g} / \mathrm{L})$ & 4 & 11 & 3 & -- \\
\hline Boron, dissolved $(\mu \mathrm{g} / \mathrm{L})$ & 4 & 680 & 320 & -- \\
\hline Lead, dissolved $(\mu \mathrm{g} / \mathrm{L})$ & 4 & $<1$ & $<1$ & - \\
\hline Lithium, dissolved $(\mu \mathrm{g} / \mathrm{L})$ & 4 & 130 & 52 & -- \\
\hline Manganese, dissolved $(\mu \mathrm{g} / \mathrm{L})$ & 5 & 270 & 14 & -- \\
\hline Mercury, dissolved $(\mu \mathrm{g} / \mathrm{L})$ & 4 & $<0.1$ & $<0.1$ & -- \\
\hline Molybdenum, dissolved $(\mu \mathrm{g} / \mathrm{L})$ & 4 & 2 & 1 & -- \\
\hline Selenium, dissolved $(\mu \mathrm{g} / \mathrm{L})$ & 4 & 1 & $<1$ & - \\
\hline Strontium, dissolved $(\mu \mathrm{g} / \mathrm{L})$ & 4 & 1,600 & 580 & -- \\
\hline
\end{tabular}

$\left[\mu \mathrm{S} / \mathrm{cm}\right.$, microsiemens per centimeter; ${ }^{\circ} \mathrm{C}$, degrees Celsius; $\mathrm{mg} / \mathrm{L}$, milligrams per liter; --, not available; <, less than; $\mu \mathrm{g} / \mathrm{L}$, micrograms per liter] 


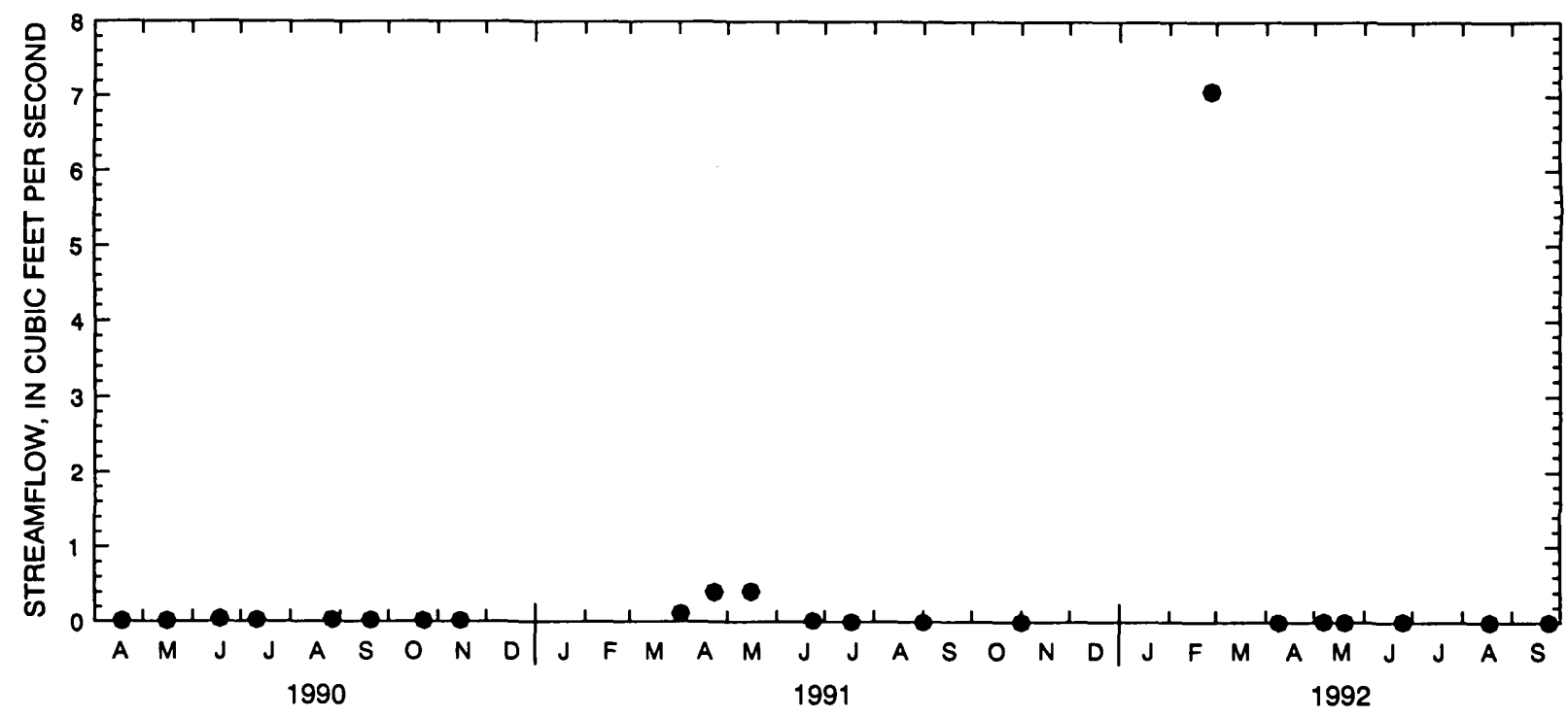

Figure 43. Streamflow measurements at the Moccasin Creek at mouth near Mandaree, North Dakota, miscellaneous discharge-measurement site, April 1990 through September 1992.

Table 18. Statistical summary of selected water-quality data for Moccasin Creek at mouth near Mandaree, N. Dak., April 1990 through September 1992

$\left[\mu \mathrm{S} / \mathrm{cm}\right.$, microsiemens per centimeter; ${ }^{\circ} \mathrm{C}$, degrees Celsius; mg/L, milligrams per liter; --, not available; <, less than; $\mu \mathrm{g} / \mathrm{L}$, micrograms per liter]

\begin{tabular}{|c|c|c|c|c|}
\hline $\begin{array}{l}\text { Physical property or } \\
\text { chemical constituent }\end{array}$ & $\begin{array}{l}\text { Number of } \\
\text { samples }\end{array}$ & Maximum & Minimum & Median \\
\hline Specific conductance $\left(\mu \mathrm{S} / \mathrm{cm}\right.$ at $\left.25^{\circ} \mathrm{C}\right)$ & 17 & 3,170 & 920 & 1,500 \\
\hline $\mathrm{pH}$, field (standard units) & 16 & 9.1 & 7.9 & 8.4 \\
\hline Oxygen, dissolved (mg/L) & 17 & 11.0 & 5.5 & 8.9 \\
\hline Hardness, total $\left(\mathrm{mg} / \mathrm{L}\right.$ as $\left.\mathrm{CaCO}_{3}\right)$ & 2 & 200 & 150 & -- \\
\hline Calcium, dissolved (mg/L) & 2 & 36 & 30 & -- \\
\hline Magnesium, dissolved (mg/L) & 2 & 26 & 18 & -- \\
\hline Sodium, dissolved $(\mathrm{mg} / \mathrm{L})$ & 2 & 360 & 190 & -- \\
\hline Sodium adsorption ratio & 2 & 11 & 7.0 & -- \\
\hline Potassium, dissolved (mg/L) & 2 & 8.3 & 6.0 & -- \\
\hline Alkalinity, dissolved $\left(\mathrm{mg} / \mathrm{L}\right.$ as $\left.\mathrm{CaCO}_{3}\right)$ & 2 & 588 & 317 & -- \\
\hline Sulfate, dissolved (mg/L) & 2 & 450 & 310 & -- \\
\hline Chloride, dissolved (mg/L) & 2 & 6.4 & 2.7 & -- \\
\hline Fluoride, dissolved (mg/L) & 2 & 0.5 & 0.2 & -- \\
\hline Silica, dissolved $(\mathrm{mg} / \mathrm{L})$ & 2 & 6.9 & 1.5 & -- \\
\hline Dissolved solids, sum of constituents (mg/L) & 2 & 1,240 & 754 & -- \\
\hline Nitrite plus nitrate, dissolved ( $\mathrm{mg} / \mathrm{L}$ as $\mathrm{N})$ & 1 & $<0.05$ & -- & \\
\hline Iron, dissolved $(\mu \mathrm{g} / \mathrm{L})$ & 2 & 800 & 55 & -- \\
\hline Manganese, dissolved $(\mu \mathrm{g} / \mathrm{L})$ & 2 & 67 & 59 & - \\
\hline
\end{tabular}




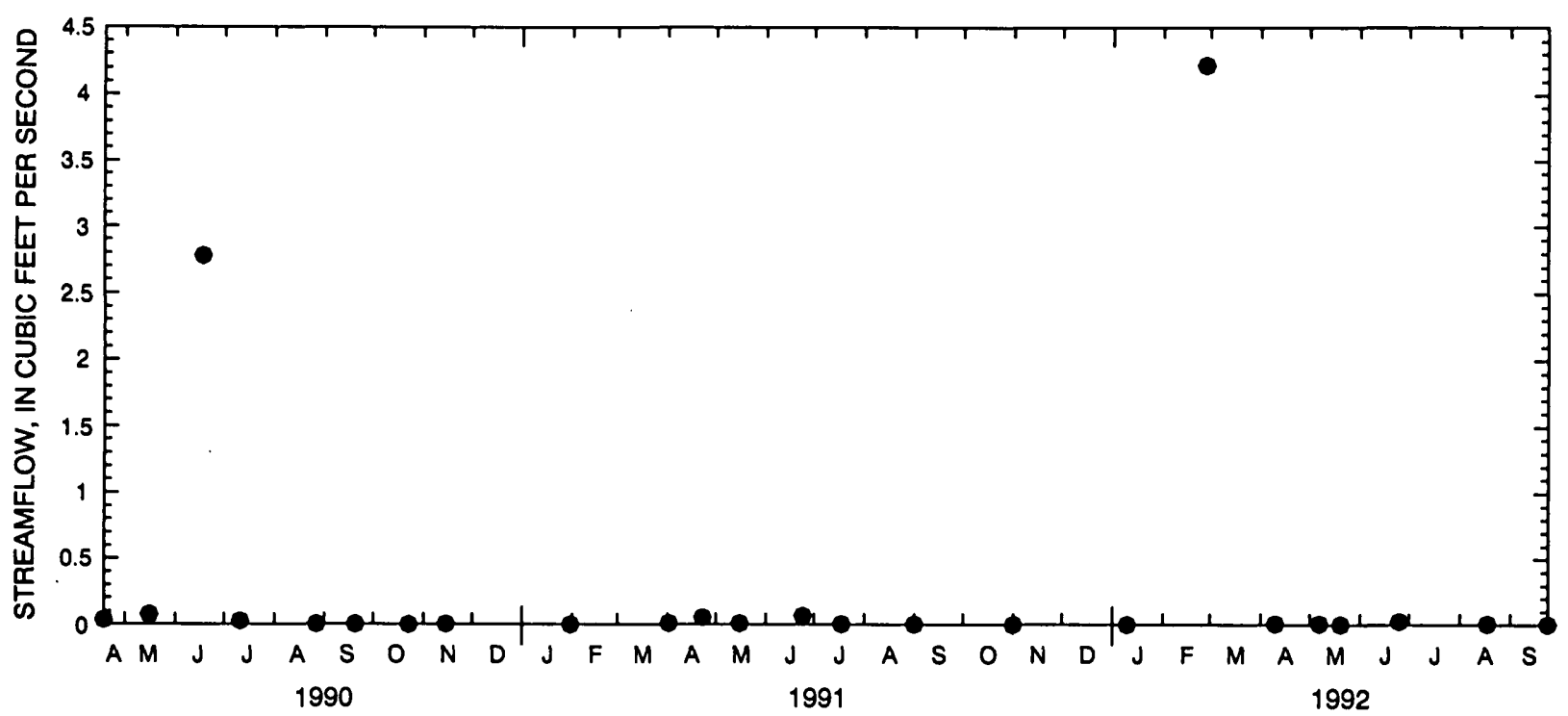

Figure 44. Streamflow measurements at the Squaw Creek above mouth near Mandaree, North Dakota, miscellaneous discharge-measurement site, April 1990 through September 1992.

Table 19. Statistical summary of selected water-quality data for Squaw Creek above mouth near Mandaree, N. Dak., April 1990 through September 1992

$\left[\mu \mathrm{S} / \mathrm{cm}\right.$, microsiemens per centimeter; ${ }^{\circ} \mathrm{C}$, degrees Celsius; $\mathrm{mg} / \mathrm{L}$, milligrams per liter; --, not available; <, less than; $\mu \mathrm{g} / \mathrm{L}$, micrograms per liter]

\begin{tabular}{|c|c|c|c|c|}
\hline $\begin{array}{l}\text { Physical property or } \\
\text { chemical constituent }\end{array}$ & $\begin{array}{l}\text { Number of } \\
\text { samples }\end{array}$ & Maximum & Minimum & Median \\
\hline Specific conductance $\left(\mu \mathrm{S} / \mathrm{cm}\right.$ at $\left.25^{\circ} \mathrm{C}\right)$ & 17 & 7,170 & 1,750 & 3,900 \\
\hline $\mathrm{pH}$, field (standard units) & 15 & 9.0 & 7.4 & 8.5 \\
\hline Oxygen, dissolved (mg/L) & 16 & 13.3 & 6.9 & 8.8 \\
\hline Hardness, total $\left(\mathrm{mg} / \mathrm{L}\right.$ as $\left.\mathrm{CaCO}_{3}\right)$ & 2 & 390 & 360 & -- \\
\hline Calcium, dissolved (mg/L) & 2 & 36 & 26 & -- \\
\hline Magnesium, dissolved (mg/L) & 2 & 74 & 72 & -- \\
\hline Sodium, dissolved $(\mathrm{mg} / \mathrm{L})$ & 2 & 1,700 & 1,300 & -- \\
\hline Sodium adsorption ratio & 2 & 37 & 30 & -- \\
\hline Potassium, dissolved (mg/L) & 2 & 11 & 10 & -- \\
\hline Alkalinity, dissolved $\left(\mathrm{mg} / \mathrm{L}\right.$ as $\left.\mathrm{CaCO}_{3}\right)$ & 2 & 1,330 & 1,080 & -- \\
\hline Sulfate, dissolved (mg/L) & 2 & 2,400 & 2,300 & -- \\
\hline Chloride, dissolved (mg/L) & 2 & 63 & 10 & -- \\
\hline Fluoride, dissolved (mg/L) & 2 & 0.9 & 0.9 & -- \\
\hline Silica, dissolved $(\mathrm{mg} / \mathrm{L})$ & 2 & 9.3 & 8.4 & -. \\
\hline Dissolved solids, residue at $180^{\circ} \mathrm{C}(\mathrm{mg} / \mathrm{L})$ & 2 & 5,090 & 4,380 & -- \\
\hline Nitrite plus nitrate, dissolved ( $\mathrm{mg} / \mathrm{L}$ as $\mathrm{N}$ ) & 1 & $<0.05$ & -. & -. \\
\hline Iron, dissolved $(\mu \mathrm{g} / \mathrm{L})$ & 2 & 80 & 50 & -- \\
\hline Manganese, dissolved $(\mu \mathrm{g} / \mathrm{L})$ & 2 & 120 & 30 & -- \\
\hline
\end{tabular}


Table 20. Peak flows for major streams on the Fort Berthold Indian Reservation

\begin{tabular}{|c|c|c|c|c|c|}
\hline \multirow{3}{*}{ Stream } & \multirow{3}{*}{ Station or site name } & \multirow{3}{*}{$\begin{array}{c}\text { Contributing } \\
\text { drainage } \\
\text { area }^{1} \\
\text { (square miles) }\end{array}$} & \multirow{2}{*}{\multicolumn{3}{|c|}{$\begin{array}{c}\begin{array}{c}\text { Peak flow } \\
\text { (cubic feet per second) }\end{array} \\
\begin{array}{c}\text { Recurrence interval } \\
\text { (years) }\end{array}\end{array}$}} \\
\hline & & & & & \\
\hline & & & 10 & 50 & 100 \\
\hline Bear Den Creek & $\begin{array}{l}\text { Bear Den Creek near Mandaree, North } \\
\text { Dakota }\end{array}$ & 74 & ${ }^{2} 1,880$ & 23,500 & 24,250 \\
\hline Shell Creek & Shell Creek near Parshall, North Dakota & 145 & ${ }^{2} 1,730$ & 23,620 & ${ }^{2} 4,640$ \\
\hline East Fork Shell Creek & $\begin{array}{l}\text { East Fork Shell Creek near Parshall, North } \\
\text { Dakota }\end{array}$ & 129 & ${ }^{3} 1,820$ & ${ }^{3} 4,000$ & ${ }^{3} 5,110$ \\
\hline Deepwater Creek & $\begin{array}{l}\text { Deepwater Creek at mouth near Raub, } \\
\text { North Dakota }\end{array}$ & 110 & ${ }^{3} 1,900$ & ${ }^{3} 4,100$ & ${ }^{3} 5,200$ \\
\hline Moccasin Creek & $\begin{array}{l}\text { Moccasin Creek at mouth near Mandaree, } \\
\text { North Dakota }\end{array}$ & 54 & ${ }^{3} 1,340$ & ${ }^{3} 2,830$ & ${ }^{3} 3,580$ \\
\hline Squaw Creek & $\begin{array}{l}\text { Squaw Creek above mouth near Mandaree, } \\
\text { North Dakota }\end{array}$ & 52 & ${ }^{3} 1,160$ & ${ }^{3} 2,500$ & ${ }^{3} 3,170$ \\
\hline
\end{tabular}

\footnotetext{
${ }^{1}$ Less than total drainage area (table 12) for all streams except Moccasin Creek.

${ }^{2}$ Determined from gaged data (Williams-Sether, 1992).

${ }^{3}$ Estimated using regression equation.
}

\section{Lake Sakakawea}

The largest surface-water body and most prominent feature on the Reservation is Lake Sakakawea (fig. 35). The lake, which is located on the Missouri River, is a manmade reservoir that began to store water in 1953. The lake has a maximum capacity of 24.1 million acre-feet and a maximum surface area of 390,000 acres (Ruddy and Hitt, 1990). The reservoir, which transects the Reservation from the northwest to the southeast, supplies drinking water to many communities and is used for irrigation and recreation. The dam supplies hydroelectric power, aids navigation downstream, and helps with flood control. The mean lake elevation for Lake Sakakawea for 1970-92 was 1,837.08 feet. The mean lake elevation for 1990-92 was $1,821.14$ feet, which is 15.94 feet lower than the elevation for 1970-92 (fig. 45). The lower elevation, which was attributed largely to the 1988-92 drought, caused water-supply problems for many communities, limited irrigation, and affected recreational activities on the lake.

\section{WATER USE}

Both ground water and surface water are used for public supplies on the Reservation. New Town (fig. 1), which has a population of 1,388, obtains water from two public-supply wells completed in the New Town aquifer. Until 1992, the town had three public-supply wells, two of which were less than 250 feet deep and one of which was between 250 and 300 feet deep. By 1993, both of the shallow wells were unusable because of lower water levels, and New Town obtained water only from the deep well. A new well was drilled in 1993 and, since then, water withdrawals have been alternated between the two wells. About 80 percent of the withdrawals are for domestic use and 20 percent are for commercial use. Annual withdrawals for New Town were 81.04 million gallons in 1990, 70.62 million gallons in 1991, and 72.76 million gallons in 1992. The average annual withdrawal for 1985-92 was 67 million gallons (W. Bratvold, New Town City Auditor, oral commun., 1993). An increase in withdrawals for 1990-93 was 


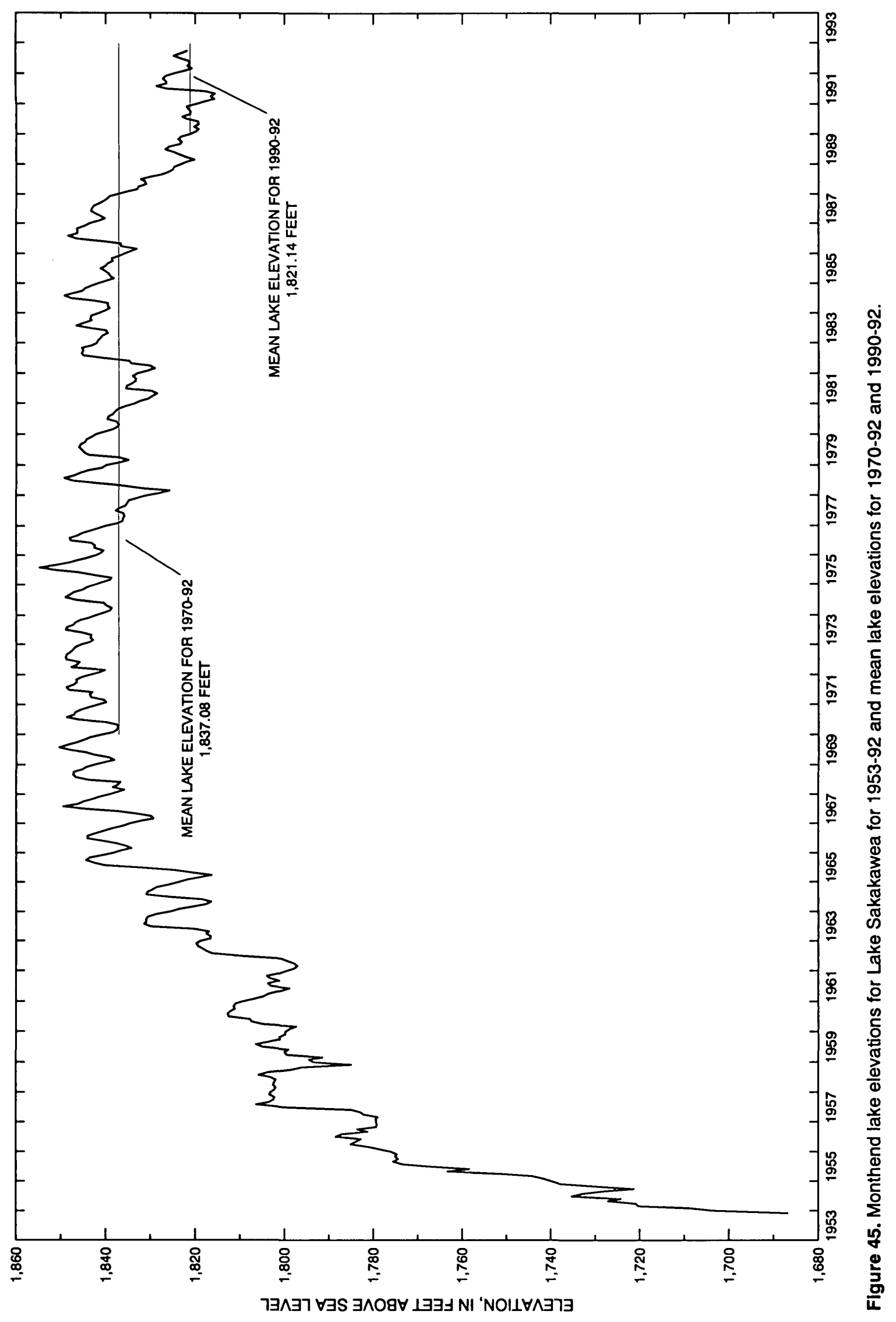


attributed to an additional water system for about 100 residents of the Fort Berthold housing development on the northeast side of New Town and to more water consumption by consumers because of the 1988-92 drought.

Four Bears housing development, located about 4 miles west of New Town, has 119 water users and obtains water from two public-supply wells that were constructed in 1981. From December 1991 to July 1993, about 50,000 gallons per day were withdrawn, and from July 1993 until 1996, about 75,000 gallons per day were withdrawn. The increase in withdrawals is attributed to the Four Bears Motor Lodge and Casino, which was established in the early 1990's.

White Shield (fig. 1), which has a population of 270, obtains water from two public-supply wells completed in the White Shield aquifer (Klausing, 1974). Annual withdrawals for White Shield are unavailable. At one time, withdrawals were estimated to be about 37,000 gallons per day (E. Morsette, Fort Berthold Indian Reservation Records Clerk, oral commun., 1993).

Parshall (fig. 1), which has a population of 943, obtains water from Lake Sakakawea. The water intake at Parshall was extended further into the lake when the 1988-92 drought caused the lake level to decrease. About 90 percent of the withdrawals are for domestic use and 10 percent are for commercial use. Annual withdrawals for Parshall are 35.25 million gallons for 1990, 37.24 million gallons for 1991, and 36.15 million gallons for 1992 (J. Embersle, Parshall Water Plant Manager, oral commun., 1993).

Mandaree (fig. 1; population data are unavailable) and Twin Buttes (fig. 1), which has a population of 140, also obtain water from Lake Sakakawea. No water-use data were available for Mandaree. For Twin Buttes, all water withdrawals are for domestic use. Annual withdrawals are 8.16 million gallons for 1990, 9.38 million gallons for 1991, and 10.04 million gallons for 1992 (P. Fredericks, Twin Buttes Water Plant Manager, oral commun., 1993).

Water use for the Reservation was estimated using 1990 data obtained from the U.S. Geological Survey State Water Use Data System (SWUDS). SWUDS contains site-specific and county data on the volume of ground water and surface water used for agricultural, commercial, rural domestic, industrial, livestock, irrigation, mining, fossil-fueled power, geothermal power, hydroelectric power, nuclear energy, sewage treatment, and public-supply needs. When possible, SWUDS site-specific data for known water users on the Reservation (for example, public supply) were used to determine water use for public supply, rural domestic, livestock, and irrigation needs (table 21). However, where SWUDS site-specific data were unavailable (for example, irrigation), water use was estimated by multiplying water-use data retrieved for each county by the percentage of county area on the Reservation (table 21). About 66 percent ( 2.27 million gallons per day) of the water use on the Reservation is for irrigation needs, 14 percent ( 0.47 million gallons per day) is for livestock needs, 14 percent $(0.47$ million gallons per day) is for publicsupply needs, and 6 percent $(0.22$ million gallons per day) is for rural domestic needs. The 0.47 -milliongallons-per-day total computed from SWUDS for public supply compared favorably with the 0.52 -milliongallons-per-day total obtained from city officials.

\section{WATER BUDGET}

A water budget is an accounting of the various components within the water cycle for a specified area and time. Water budgets are useful for comparing the relative importance of the different components and for indicating general interactions among the components. A simple water-budget equation is

$$
\text { inflow }- \text { outflow }=\text { change in storage. }
$$

If, over a long enough time, no change occurs in storage, then outflow must equal inflow. 
Table 21. Estimated water use on the Fort Berthold Indian Reservation, 1990

[Numbers were rounded]

\begin{tabular}{|c|c|c|c|c|c|c|}
\hline \multirow{2}{*}{ County } & \multirow{2}{*}{$\begin{array}{c}\text { Percent of } \\
\text { county that is } \\
\text { on Reservation }\end{array}$} & \multicolumn{5}{|c|}{$\begin{array}{c}\text { Water use } \\
\text { (million gallons per day) }\end{array}$} \\
\hline & & $\begin{array}{l}\text { Public } \\
\text { supply }\end{array}$ & $\begin{array}{c}\text { Rural } \\
\text { domestic }\end{array}$ & Livestock & Irrigation & Tota \\
\hline Dunn & 20 & 0.052 & 0.042 & 0.192 & 0.080 & 0.366 \\
\hline McKenzie & 6 & .036 & .020 & .051 & .974 & 1.08 \\
\hline McLean & 20 & .207 & .072 & .094 & .770 & 1.14 \\
\hline Mercer & 8 & .046 & .014 & .038 & .331 & .429 \\
\hline Mountrail & 23 & .126 & .058 & .087 & .106 & .377 \\
\hline Ward & 1 & 0 & .013 & .005 & .010 & .028 \\
\hline Total & & .467 & .219 & .467 & 2.27 & 3.42 \\
\hline
\end{tabular}

A complete water budget for the Reservation is difficult to determine, and many hydrological, climatological, and biological components must be factored into the equation to obtain an accurate budget. It was not possible to determine a balanced water budget for the Reservation because of insufficient data. However, data values estimated for selected components from the best available data for 1970-92 and 1990-92 are shown in table 22.

Table 22. Selected water-budget component rates and storage values for the Fort Berthold Indian Reservation [Inflow and outflow rates are in acre-feet per year; storage values are in acre-feet]

\begin{tabular}{|c|c|c|}
\hline & $1970-92$ & $1990-92$ \\
\hline \multicolumn{3}{|l|}{ Inflow } \\
\hline Missouri River near Culbertson, Montana & $8,033,000$ & $5,698,000$ \\
\hline Yellowstone River near Sidney, Montana & $8,989,000$ & $7,832,000$ \\
\hline Little Missouri River near Watford City, North Dakota & 380,200 & 92,400 \\
\hline Tributary inflow from outside of study area & 48,300 & 48,300 \\
\hline $\begin{array}{l}\text { Precipitation over study area (16.58 inches per year during } 1970-92 ; 16.28 \\
\text { inches per year during } 1990-92)\end{array}$ & $1,400,000$ & $1,370,000$ \\
\hline \multicolumn{3}{|l|}{ Outflow } \\
\hline Missouri River at Garrison Dam, North Dakota & $16,490,000$ & $12,470,000$ \\
\hline Evaporation from Lake Sakakawea & 519,000 & 519,000 \\
\hline Evapotranspiration over study area & $2,605,000$ & $2,605,000$ \\
\hline Public water supply & 600 & 600 \\
\hline Estimated other water use & 3,300 & 3,300 \\
\hline \multicolumn{3}{|l|}{ Storage } \\
\hline Lake Sakakawea & $18,100,000$ & $13,600,000$ \\
\hline Ground water in major aquifers & $94,414,000$ & $94,414,000$ \\
\hline
\end{tabular}

Inflow to the Reservation from the Missouri and Little Missouri Rivers was estimated using gage records for the Missouri River near Culbertson, Mont. (06185500), Yellowstone River near Sidney, Mont. 
(06329500), and Little Missouri River near Watford City, N. Dak. (06337000) (fig. 46). Combined mean inflow at the three stations for 1970-92 was 17,402,200 acre-feet (table 22). In contrast, combined mean inflow for 1990-92 was 13,622,400 acre-feet.

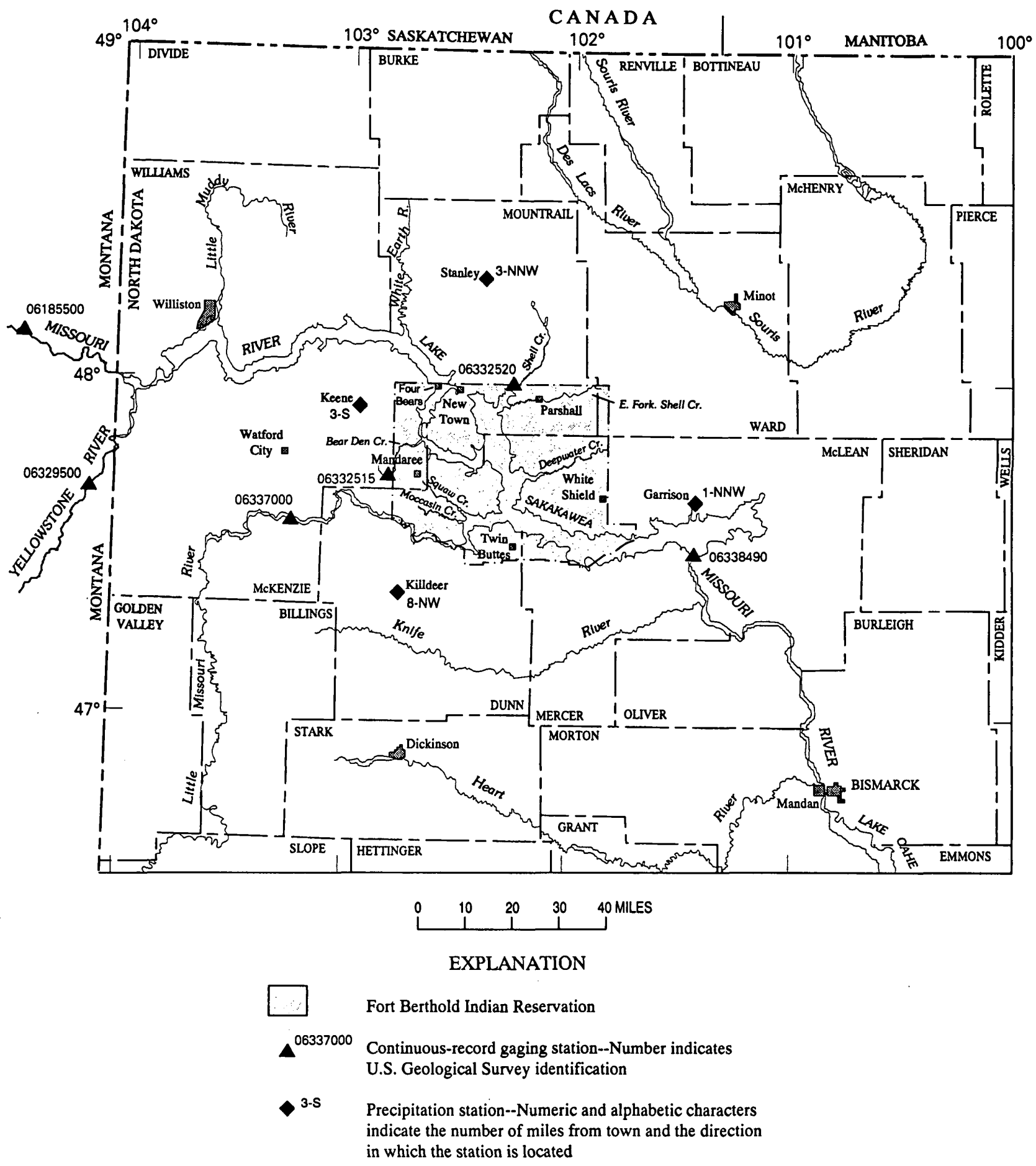

Figure 46. Locations of selected continuous-record gaging stations, precipitation stations, and towns near the Fort Berthold Indian Reservation. 
Tributary inflow to the Reservation in the four major streams that extend beyond the Reservation was estimated as 48,300 acre-feet per year (table 22). This value was determined by using the multiple stepwise-regression equation discussed previously to compute the mean annual flow for each of the six major streams and then subtracting the mean annual flow contributed by the drainage area of those six streams that lies within the Reservation. The combined contribution from all drainage areas within the Reservation was 69,300 acre-feet per year. Results are the same for both 1970-92 and 1990-92 because the computation depends only on drainage area.

Precipitation data are not available for the Reservation. Therefore, mean annual precipitation for the Reservation was estimated by averaging precipitation data for four National Weather Service precipitation stations--Stanley 3-NNW, Garrison 1-NNW, Killdeer 8-NW, and Keene 3-S (the numeric and alphabetic characters after each name indicate the number of miles from town and the direction in which the precipitation station is located; fig. 46). Mean annual precipitation was 16.58 inches for 1970-92 and 16.28 inches for 1990-92 (table 22). Inflow to the Reservation from precipitation was calculated by multiplying those precipitation rates by the area of the Reservation (1,583 square miles) and applying the appropriate unit conversions.

Outflow from the Reservation included discharge from the Missouri River at Garrison Dam. Annual mean outflow for the Missouri River at Garrison Dam, N. Dak., gaging station (06338490; fig. 46) was $16,490,000$ acre-feet for 1970-92 and 12,470,000 acre-feet for 1990-92 (table 22).

Evaporation (water loss from water bodies) and transpiration (water loss caused by the water-vapor diffusion of plants) also are outflow components of the water budget. Evaporation from Lake Sakakawea was calculated by multiplying the area of the lake within the Reservation ( 263 square miles) by the evaporation rate of 37 inches per year (Farnsworth and others, 1982). Average annual evaporation from Lake Sakakawea is 519,000 acre-feet (table 22). Evapotranspiration from the remaining area of the Reservation was estimated as average precipitation less average runoff multiplied by the area of the Reservation not covered by the lake (1,320 square miles) and applying the appropriate unit conversions. This results in an average evapotranspiration of $1,050,000$ acre-feet per year.

Water use on the Reservation is a small component in the overall water budget. The 0.52 million gallons per day of public water supply determined for this study is equivalent to about 600 acre-feet per year. Other water use totalled 2.96 million gallons per day or about 3,800 acre-feet per year. Total water use on the Reservation was estimated to be 3,900 acre-feet per year using 1990 county statistics (table 22).

Change in storage within the Reservation was not computed for 1970-92 or 1990-92. However, substantial storage capability exists. The storage capacity for Lake Sakakawea was determined from storage-capacity tables supplied by the U.S. Army Corps of Engineers (written commun., 1984). The mean lake elevation for $1970-92$ was $1,837.08$ feet, and storage capacity was $18,100,000$ acre-feet (table 22). The mean lake elevation for 1990-92 was $1,821.14$ feet, and storage capacity was $13,600,000$ acre-feet. The amount of ground water in storage in the three bedrock aquifers and the five buried-valley aquifers on the Reservation is about $94,414,000$ acre-feet.

\section{SUMMARY}

Water resources of the Fort Berthold Indian Reservation in west-central North Dakota occur as ground water in bedrock and buried-valley aquifers and as surface water in streams and Lake Sakakawea. The bedrock aquifers--the Fox Hills-Hell Creek, Tongue River, and Sentinel Butte--store about 93 million acre-feet of water under the Reservation. The Fox Hills-Hell Creek aquifer is composed mainly of very 
fine to medium-grained sandstone interbedded with siltstone and shale. About 51 million acre-feet of water is stored in the aquifer, which is under artesian pressure. Water levels in the aquifer declined almost 1 foot per year from 1976 through 1992. Water in the aquifer is a sodium bicarbonate type and had a mean dissolved-solids concentration of 1,530 milligrams per liter.

The Tongue River aquifer is composed mainly of claystones and siltstones and has widely distributed pockets of sandstone or lignite layers. About 24 million acre-feet of water is stored in the aquifer. The water varies from a sodium bicarbonate type to a mixed calcium magnesium sodium sulfate type and had a mean dissolved-solids concentration of 2,110 milligrams per liter.

The Sentinel Butte aquifer is composed mainly of interbedded claystones, siltstones, shale, lignite, and sandstone. Yields from the lignite beds are highly variable. About 18 million acre-feet of water is stored in the aquifer. The water varies from a sodium bicarbonate type to a mixed calcium magnesium sodium sulfate type and had a mean dissolved-solids concentration of 1,300 milligrams per liter.

The East Fork Shell Creek, Shell Creek, White Shield, New Town, and Sanish aquifers occur within buried valleys and store about 1,414,000 acre-feet of water. The East Fork Shell Creek and Shell Creek aquifers range from 0.75 to 2 miles in width and are about 100 feet deep. The aquifers are composed of sand and gravel lenses that are surrounded by less-permeable till. Water in the East Fork Shell Creek aquifer is a sodium sulfate bicarbonate type and had a mean dissolved-solids concentration of 3,220 milligrams per liter. Water in the Shell Creek aquifer is a sodium bicarbonate sulfate type and had a mean dissolved-solids concentration of 1,470 milligrams per liter.

The White Shield aquifer lies within a buried valley and has an areal extent of about 48 square miles within the Reservation. The aquifer is composed of very fine to coarse sand and fine to coarse gravel and ranges from 18 to 226 feet in thickness. Data indicate that the White Shield aquifer is separated into two parts. Water in both parts of the aquifer varies from a sodium bicarbonate sulfate type to a mixed calcium magnesium sodium bicarbonate sulfate type. The mean dissolved-solids concentration in the eastern part of the aquifer was 1,080 milligrams per liter, and the mean dissolved-solids concentration in the western part of the aquifer was 1,430 milligrams per liter. Water levels in the western part of the aquifer rose during 1970-92.

The New Town aquifer lies within a buried valley that is as much as 307 feet deep and between 1.75 and 4.7 miles wide. The aquifer has an areal extent of about 18 square miles within the Reservation. The aquifer is composed of lenticular deposits of sand and gravel and is confined by at least 50 feet of till and clay. Water in the aquifer is a calcium sodium bicarbonate sulfate type and had a mean dissolvedsolids concentration of 1,390 milligrams per liter. Data indicate a close correspondence between groundwater levels and lake stage of Lake Sakakawea, implying a hydraulic connection between the aquifer and the lake.

The Sanish aquifer has an areal extent of about 8.5 square miles. The aquifer is composed of sand, clayey sand, and thin gravels at the base of the buried valley. The aquifer matrix is poorly cemented and highly permeable. Water in the aquifer is a mixed calcium magnesium bicarbonate sulfate type and had a mean dissolved-solids concentration of 1,350 milligrams per liter.

Most of the springs on the Reservation are located south of Lake Sakakawea and flow from the Sentinel Butte aquifer. Most of the springs are seasonal seeps and have flows of less than 1 gallon per minute. Water in the springs varies from a sodium bicarbonate sulfate type to a mixed calcium magnesium sodium bicarbonate sulfate type and had a mean dissolved-solids concentration of 1,080 milligrams per liter. 
Major streams on the Reservation are Bear Den Creek, Shell Creek, East Fork Shell Creek, Deepwater Creek, Moccasin Creek, and Squaw Creek. The drainage basins of Moccasin Creek and Squaw Creek are located entirely within the Reservation, but large parts of the other drainage basins are located outside of the Reservation.

Seasonal variations in streamflow correspond to seasonal variations in precipitation, snowmelt, and evapotranspiration. Bear Den Creek has a drainage area of 117 square miles, of which 34 square miles are within the Reservation. Mean streamflow at the Bear Den Creek near Mandaree, N. Dak., gaging station for June 1966 through September 1992 was 6.72 cubic feet per second. Shell Creek has a drainage area of 465 square miles, of which 30 square miles are within the Reservation. Mean streamflow at the Shell Creek near Parshall, N. Dak., gaging station for September 1965 through September 1981 was 12.9 cubic feet per second. East Fork Shell Creek has a drainage area of 467 square miles, of which 125 square miles are within the Reservation. From July 1991 through September 1992, instantaneous streamflow at the East Fork Shell Creek near Parshall, N. Dak., gaging station ranged from zero on many days to 59 cubic feet per second on March 1, 1992. Streamflow measurements for April 1990 through June 1991 ranged from zero in some months to 3.65 cubic feet per second on March 28, 1991. Deepwater Creek has a drainage area of 235 square miles, of which 212 square miles are within the Reservation. Streamflow measurements at the Deepwater Creek at mouth near Raub, N. Dak., gaging station for April 1990 through May 1991 ranged from zero on many days to 4.28 cubic feet per second on March 28, 1991. From July 1991 through September 1992, instantaneous streamflow ranged from zero on many days to 50 cubic feet per second on February 29, 1992. Moccasin Creek has a drainage area of 54 square miles, all of which lie within the Reservation. Streamflow measurements at the Moccasin Creek at mouth near Mandaree, N. Dak., miscellaneous site for April 1990 through September 1992 ranged from zero on many days to 7.07 cubic feet per second on January 10, 1992. Squaw Creek has a drainage area of 58 square miles, all of which lie within the Reservation. Streamflow measurements at the Squaw Creek above mouth near Mandaree, N. Dak., miscellaneous site for April 1990 through September 1992 ranged from zero on many days to 4.22 cubic feet per second on February 27, 1992.

Basin and climatic characteristics for selected gaging stations near the Reservation were used to develop a regression equation for estimating mean annual streamflow for ungaged streams on the Reservation. A multiple stepwise-regression analysis was used to relate streamflow to a set of basin and climatic characteristics. The only characteristic that was significant at the 95 -percent confidence level was drainage area.

Lake Sakakawea has a maximum surface area of 390,000 acres. The surface area is variable in relation to lake stage, which was unusually low during this study. The mean lake elevation for Lake Sakakawea for $1970-92$ was $1,837.08$ feet, and the mean elevation for $1990-92$ was $1,821.14$ feet, which is 15.94 feet lower than the mean elevation for 1970-92.

Both ground water and surface water are used for public supplies on the Reservation. About 66 percent of the water use on the Reservation is for irrigation needs, 14 percent is for livestock needs, 14 percent is for public-supply needs, and 6 percent is for rural domestic needs.

The major inflow component of a general water budget developed for the Reservation was inflow from the Missouri and Little Missouri Rivers. For 1970-92, mean inflow for the Missouri and Little Missouri Rivers was 17,402,200 acre-feet, mean annual precipitation was 1,400,000 acre-feet, and annual mean outflow for the Missouri River at Garrison Dam, N. Dak., was 16,490,000 acre-feet. The mean lake elevation for Lake Sakakawea for 1970-92 was 1,837.08 feet, and storage capacity was $18,100,000$ acrefeet. Ground-water storage in the the three bedrock aquifers and the five buried-valley aquifers is about $94,414,000$ acre-feet. 


\section{REFERENCES}

Armstrong, C.A., 1969, Geology and ground water resources of Burke and Mountrail Counties, part II, Ground water basic data: North Dakota Geological Survey Bulletin 55 and North Dakota State Water Commission County Ground Water Studies 14, 282 p.

1971, Ground-water resources of Burke and Mountrail Counties: North Dakota Geological Survey Bulletin 55, pt. III, and North Dakota State Water Commission County Ground Water Studies 14, pt. III, 86 p.

Bluemle, J.P., 1971, Geology of McLean County, North Dakota: North Dakota Geological Survey Bulletin 60, pt. I, and North Dakota State Water Commission County Ground Water Studies 19, pt. I, 65 p.

1989, Geology of Renville and Ward Counties, North Dakota: North Dakota Industrial Commission, Geological Survey Division, Bulletin 50, pt. I, and North Dakota State Water Commission County Groundwater Studies 11, pt. I, 62 p.

Bluemle, M.E., 1978, Status of mineral resources information for the Fort Berthold Indian Reservation, North Dakota: Administrative Report BIA-40, 81 p.

Carlson, C.G., 1973, Geology of Mercer and Oliver Counties, North Dakota: North Dakota Geological Survey Bulletin 56, pt. I, and North Dakota State Water Commission County Ground Water Studies 15, pt. I, 72 p.

1985, Geology of McKenzie County, North Dakota: North Dakota Geological Survey Bulletin 80, pt. I, and North Dakota State Water Commission County Groundwater Studies 37, pt. I, 48 p.

Clayton, Lee, 1972, Geology of Mountrail County, North Dakota: North Dakota Geological Survey Bulletin 55, pt. IV, and North Dakota State Water Commission Ground Water Study 14, pt. IV, 70 p.

Comeskey, A.E., 1989, Hydrology of the Plaza area, Mountrail County, North Dakota: North Dakota State Water Commission Ground-Water Studies Number 94, 64 p.

Croft, M.G., 1970, Ground water basic data, Mercer and Oliver Counties, North Dakota: North Dakota Geological Survey Bulletin 56, pt. II, and North Dakota State Water Commission County Ground Water Studies 15, pt. II, $268 \mathrm{p}$.

1973, Ground-water resources, Mercer and Oliver Counties, North Dakota: North Dakota Geological Survey Bulletin 56, pt. III, and North Dakota State Water Commission County Ground Water Studies 15, pt. III, 81 p.

1985a, Ground-water data for McKenzie County, North Dakota: North Dakota Geological Survey Bulletin 80, pt. II, and North Dakota State Water Commission County Ground-Water Studies 37, pt. II, 455 p.

-1985b, Ground-water resources of McKenzie County, North Dakota: North Dakota Geological Survey Bulletin 80, pt. III, and North Dakota State Water Commission County Ground-Water Studies 37, pt. III, 57 p.

Dingman, R.J., and Gordon, E.D., 1954, Geology and ground-water resources of the Fort Berthold Indian Reservation, North Dakota: U.S. Geological Survey Water-Supply Paper 1259, 115 p.

Farnsworth, R.K., Thompson, E.S., and Peck, E.L., 1982, Evaporation atlas for the contiguous 48 United States: U.S. Department of Commerce, National Oceanic and Atmospheric Administration, Technical Report NWS 33, 27 p.

Groenewold, G.H., Hemish, L.A., Cherry, J.A., Rehm, B.W., Meyer, G.N., and Winczewski, L.M., 1979, Geology and geohydrology of the Knife River Basin and adjacent areas of west-central North Dakota: North Dakota Geological Survey Report of Investigation No. 64, 402 p.

Klausing, R.L., 1971, Ground water basic data, McLean County, North Dakota: North Dakota Geological Survey Bulletin 60, pt. II, and North Dakota State Water Commission County Ground Water Studies 19, pt. II, 468 p. 
1974, Ground-water resources of McLean County, North Dakota: North Dakota Geological Survey

Bulletin 60, pt. III, and North Dakota State Water Commission County Ground-Water Studies 19, pt. III, 73 p.

1976, Ground-water basic data for Dunn County, North Dakota: North Dakota Geological Survey

Bulletin 68, pt. II, and North Dakota State Water Commission County Ground-Water Studies 25, pt. II, 501 p.

1979, Ground-water resources of Dunn County, North Dakota: North Dakota Geological Survey Bulletin 68, pt. III, and North Dakota State Water Commission County Ground-Water Studies 25, pt. III, 48 p.

North Dakota Department of Health, 1994, Public water supply systems in North Dakota, chapter 33-17-01:

Bismarck, North Dakota, $43 \mathrm{p}$.

Pettyjohn, W.A., 1968, Geology and ground water resources of Renville and Ward Counties, part 2, Ground water basic data: North Dakota Geological Survey Bulletin 50 and North Dakota State Water Commission County Ground Water Studies 11, 302 p.

Pettyjohn, W.A., and Hutchinson, R.D., 1971, Ground-water resources of Renville and Ward Counties: North Dakota Geological Survey Bulletin 50, pt. III, and North Dakota State Water Commission County Ground Water Studies 11, pt. III, 100 p.

Ruddy, B.C., and Hitt, K.J., 1990, Summary of selected characteristics of large reservoirs in the United States and Puerto Rico, 1988: U.S. Geological Survey Open-File Report 90-163, 295 p.

Schmid, R.W., and Ziegler, V.E., 1962, Ground water conditions in the vicinity of Parshall, Mountrail County, North Dakota: North Dakota State Water Conservation Commission North Dakota Ground Water Studies No. 41, 31 p.

Shaver, R.B., and Pusc, S.W., 1992, Hydraulic barriers in Pleistocene buried-valley aquifers: Ground Water, v. 30, no. 1, p. 21-28.

Thomas, D.M., and Benson, M.A., 1970, Generalization of streamflow characteristics from drainage-basin characteristics: U.S. Geological Survey Water-Supply Paper 1975, 55 p.

U.S. Department of Commerce, National Oceanic and Atmospheric Administration, Environmental Data Service, 1972-93, Climatological data, North Dakota, Annual summaries, 1971-92: Asheville, North Carolina, v. 80-101, no. 13 , unpaginated.

U.S. Environmental Protection Agency, 1996, Drinking water regulations and health advisories: EPA 822-R-001, $11 \mathrm{p}$.

U.S. Geological Survey, 1966-93, Water resources data, North Dakota, Water years 1965-92: U.S. Geological Survey Water-Data Report ND-66-1 through ND-93-1, various pagination.

U.S. Salinity Laboratory Staff, 1954, Diagnosis and improvement of saline and alkali soils: Department of Agriculture, Agriculture Handbook 60, 160 p..

Wald, J.D., and Cates, S.W., 1995, Water-resources data for the Fort Berthold Indian Reservation, west-central North Dakota: U.S. Geological Survey Open-File Report 95-304, 272 p.

Williams-Sether, Tara, 1992, Techniques for estimating peak-flow frequency relations for North Dakota streams: U.S. Geological Survey Water-Resources Investigations Report 92-4020, 57 p. 